\title{
RECN512: Practicum
}

2003

Heritage Inventory

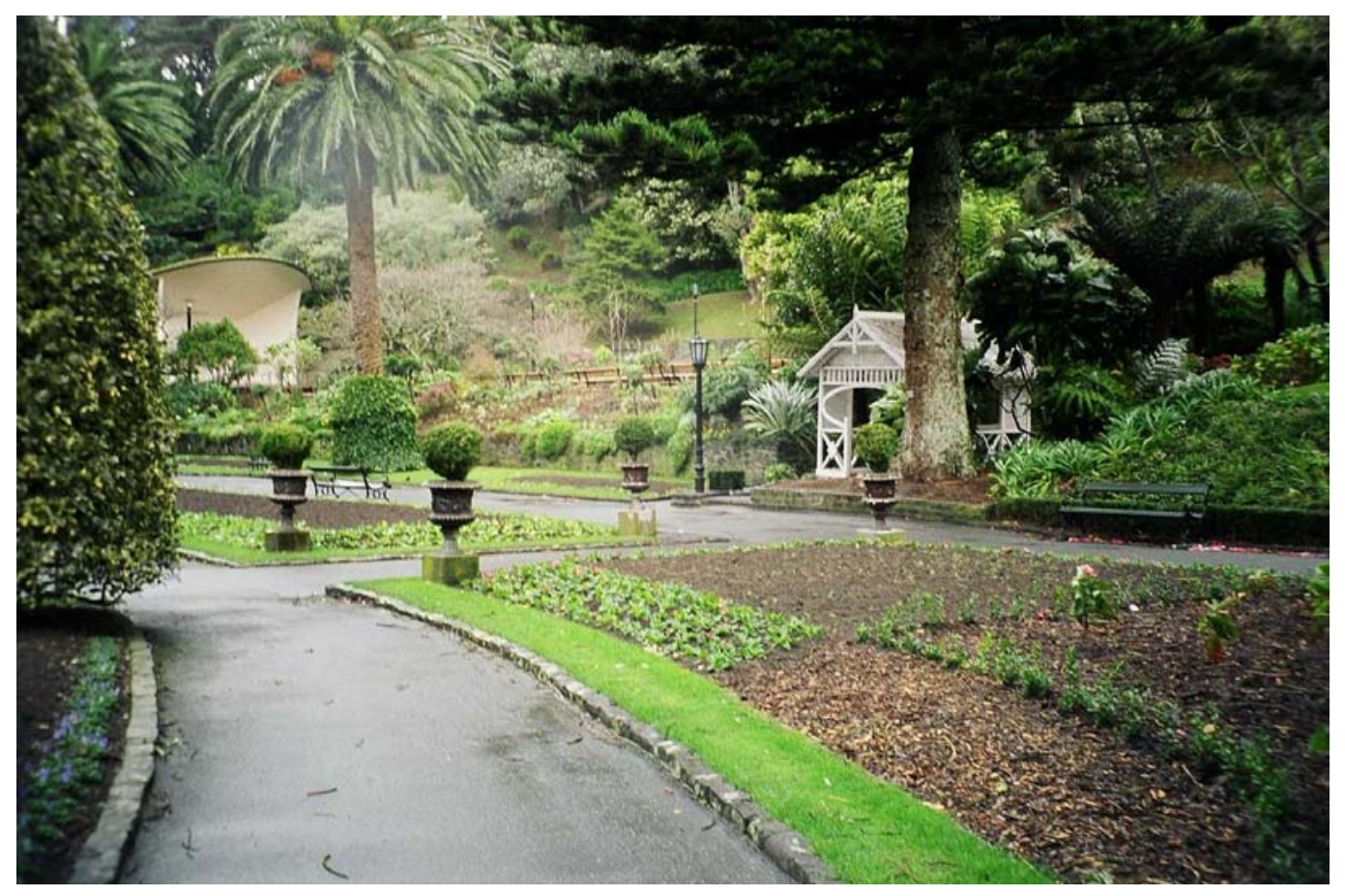

\section{Wellington Botanic Garden}

\author{
Marguerite Hill
}


$\underline{\text { Table of Contents }}$

Acknowledgements 3

$\begin{array}{ll}\text { Project Brief } & 4\end{array}$

Introduction (Current Status)

General Description 4

Current Ownership and Status 4

Boundary Map 5

Overall Significance $\quad 7$

$\begin{array}{ll}\text { History } & 10\end{array}$

Maori 10

European Settlement 10

Establishment of the Botanic Garden 13

$\begin{array}{ll}\text { The Vesting Act } & 21\end{array}$

The Gardens Battery $\quad 25$

The Observatory Site $\quad 25$

The Royal Botanic Garden at Kew $\quad 26$

The Botanic Garden, fashion and garden styles 26

Heritage Inventory $\quad 29$

Notes of the Inventory 29

Botanic Garden Key 32

Botanic Garden Map 33

Buildings in the Botanic Garden 34

Features of the Botanic Garden 54

Spaces in the Botanic Garden 68

Buildings that are closely associated with the Botanic Garden $\quad 77$

Spaces that are closely associated with the Botanic Garden 95

$\begin{array}{ll}\text { Recommendations } & 100\end{array}$

$\begin{array}{ll}\text { Appendix } & 104\end{array}$

$\begin{array}{ll}\text { List of Sources } & 113\end{array}$ 


\section{Acknowledgements:}

Thank you to Robert McClean and the librarian at the Historic Places Trust. Thanks also to Mike Oates and Nonda Katsos at the Wellington Botanic Garden. Thank you to staff at Wellington City Archive. Thanks to Winsome Shepherd and Walter Cook for their history of the Wellington Botanic Garden which was invaluable to me. Thank you to Andrew Cullen for his support and help. 


\section{Project Brief}

The purpose of this Heritage Inventory is to identify, research and assess heritage features in the Wellington Botanic Garden and surrounding area. The resulting heritage inventory will be made available to the Wellington City Council to help with the future management of the heritage features within the Botanic Garden. The inventory could also be used by the New Zealand Historic Places Trust as a background for a possible proposal to register the Botanic Garden, or the buildings, features or spaces within it, as an historic area or historic place/s.

\section{Introduction (Current Status)}

\section{General Description}

The Wellington Botanic Garden Founders Entrance is located on Glenmore Street. There are also entrances on Salamanca Rd, Glen Terrace, through the Cable Car on Upland Rd and through the Bolton Street Memorial Park. The Botanic Garden is a mixed garden including the original 13 acres set aside by Wakefield in the New Zealand Company's survey of Wellington. The Botanic Garden is now 25 hectares in size, and is described by Wellington City Council as a 'park with botanical collections, comprising a mixture of formal garden areas, native forest remnants and pine plantations'. The native forest elements and conifers create the framework and shelter for the Garden. ${ }^{1}$

\section{Current Ownership and Status}

The Wellington Botanic Garden is owned by the Wellington City Council and is a designated Local Purpose (Public Gardens) Reserve. The title for the Botanic Garden is as below:

Pt Lot 1 D P 8530 (24.8382 ha), Wellington Botanic Garden Local Purpose Reserve (Public Gardens), Gazette 1995, page 4324

Lot 2 DP 74620 (0.0405 ha), Wellington Botanic Garden Local Purpose Reserve (Public Gardens), Gazette 1995, page 4324

Sec 1224, Town of Wellington, SO 25200, (0.1410 ha), Wellington Botanic Garden Local Purpose Reserve (Public Gardens), Gazette 1995, page 4324

Sec 1225, Town of Wellington, SO 252000 (0.0452 ha), Wellington Botanic Garden Local Purpose Reserve (Public Gardens), Gazette 1995, page 4324

Lot 1 DP 55960 (0.2840 ha), Wellington Botanic Garden Local Purpose Reserve (Public Gardens), Gazette 1995, page 4324

Lot 2 DP 55960 (0.1353 ha), Wellington Botanic Garden Local Purpose Reserve (Public Gardens), Gazette 1995, page 4324

1 Wellington City Council, Combined Management Plan, Wellington Botanic Garden, Anderson Park and Bolton Street Memorial Park, January 2002, pp. 24, 27. 


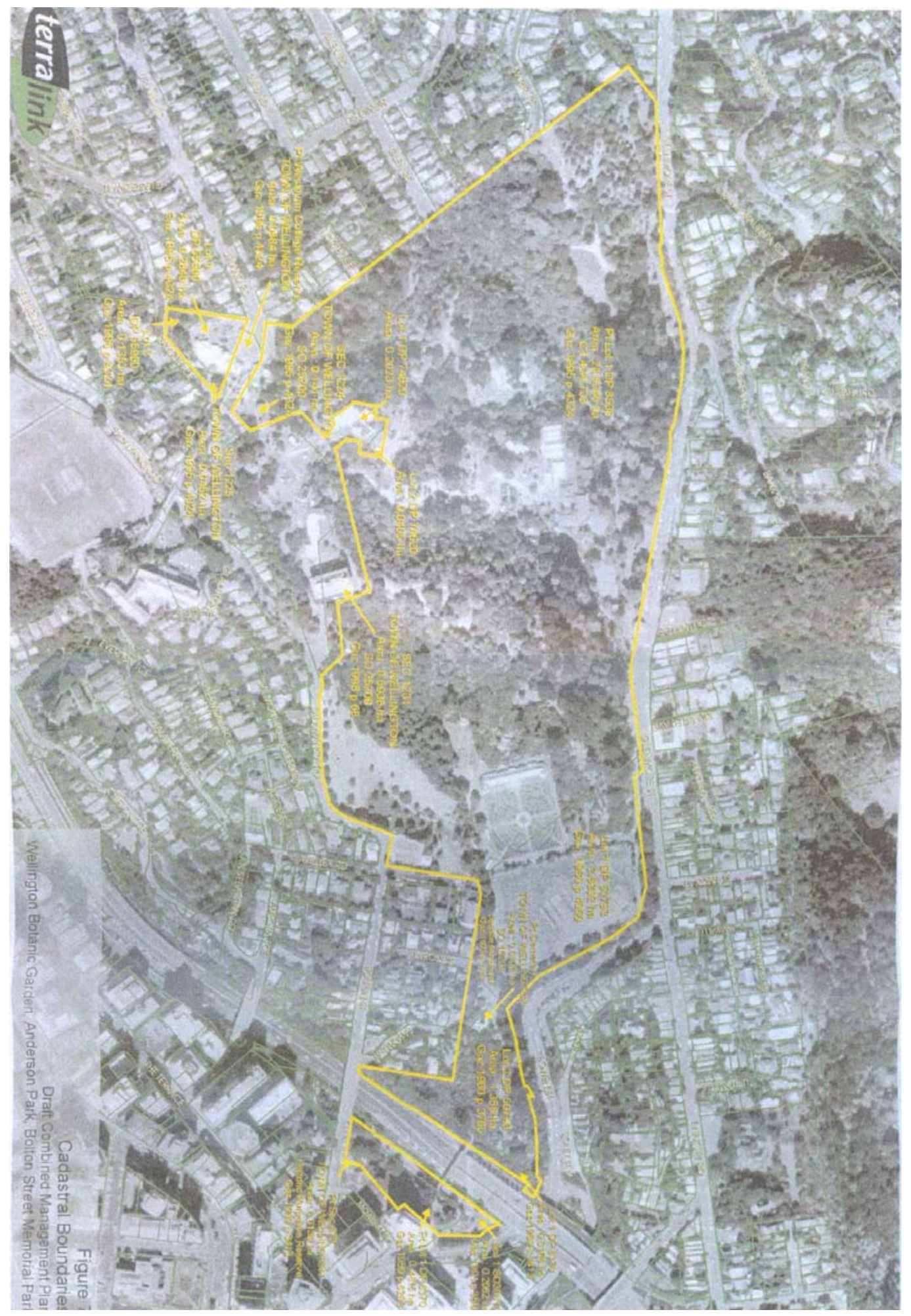

Map showing boundaries [Source: Wellington City Council]. 
The Botanic Garden is administered by the Parks and Gardens Business Unit at the Wellington City Council. Mike Oates is the Manager of Natural and Botanic Areas and oversees Wellington's botanic gardens. The Botanic Garden is listed as a Heritage Area under the Wellington City District Plan and is also part of the Wellington City Council's Recreation and Open Space Strategies. ${ }^{2}$ A Combined Management Plan which includes the Botanic Garden, Bolton Street Memorial Park and Anderson Park 'provide[s] for and ensure[s] the use, enjoyment, maintenance, protection and preservation' of the three botanic gardens. The Combined Management Plan guarantees that the 'landscape character, atmosphere and scenic amenity of the Garden shall be protected'. ${ }^{3}$ Three buildings or features are named specifically under the District Plan: the gazebo/summerhouse, the entrance gates and fence, and the Overseer's Cottage. ${ }^{4}$ These buildings and features are also recognised in the Heritage Inventory.

- The Overseer's Cottage is recognised by the New Zealand Historic Places Trust while the Dominion Observatory is recognised by both the New Zealand Historic Places Trust and the Wellington City District Plan, as is the Carter Observatory, New Zealand's National Observatory.

- The Overseer's Cottage, Gazebo/ summerhouse and the Main Entrance Gates are recognised by the District Plan. The Cable Car Winding House is also mentioned in the District Plan.

- The Sexton's Cottage at Bolton Street Memorial Park is recognised by both the New Zealand Historic Places Trust and the Wellington City District Plan.

- The Mess Room and Stables appear in the Wellington City Council Heritage Inventory. The Meteorological Office is also recognised in the Wellington City Council Heritage Inventory.

- The historic path names are mentioned in the Combined Management Plan. ${ }^{5}$

- Bolton Street Memorial Park is recognised a designated Historic Reserve under the Wellington City District Plan. It is also a Historic Place under the New Zealand Historic Places Act 1993. ${ }^{6}$

The Combined Management Plan states that 'advice from suitably qualified historians, artisans and the New Zealand Historic Places Trust shall be sought on issues relating to the conservation of specific features'. ${ }^{7}$ There are similar policies relating to the natural heritage and tree framework of the Botanic Garden.

The Botanic Garden Advisory Board was established in 1997 to advise on the development of the four botanic gardens in Wellington (Wellington Botanic Garden, Otari Wilton's Bush, Truby King Park and the Bolton Street Memorial Park). The Board reviews proposals and supports the Curator/Manager in 'establishing and maintaining the Botanic Gardens in Wellington as nationally and internationally recognised gardens and botanic collections'. ${ }^{8}$

\footnotetext{
2 Wellington City Council, pp. 27, 91.

${ }^{3}$ Wellington City Council, p. 27.

${ }^{4}$ Wellington City Council, p. 28.

${ }^{5}$ Wellington City Council, p. 49.

${ }^{6}$ Please see separate listings for each building or area.

${ }^{7}$ Wellington City Council, p. 28.

${ }^{8}$ Wellington City Council, pp. 16, 82.
} 


\section{Overall Significance}

The Wellington Botanic Garden is significant for many reasons. The Botanic Garden has an important role in the history of New Zealand and Wellington City. This includes the Botanic Garden's role in establishing plant trials and its impact on New Zealand forestry. The Botanic Garden is significant because of the botanical and horticultural work it does for the region and the country, as well as its educational role in the community.

According to a 1984 article in Royal Horticultural Institute's Annual Journal, Wellington Botanic Garden is one of New Zealand's most significant gardens. The Garden's place as a ground for plant trials and conifer growing demonstrates the importance of the Garden in New Zealand's history. The pines now make up the skyline of the Botanic Garden and many other places in New Zealand. The protection of the native bush remnant as early as the 1870s makes the Wellington Botanic Garden unique. ${ }^{9}$ Areas of original native bush remnant remain at the Botanic Garden, linking us to the days before European settlement. The oldest tree in the Botanic Garden is a hinau, which is about 250 years old. ${ }^{10}$

The Wellington Botanic Garden is a public treasure and is an important tourist attraction for visitors to Wellington City. It also serves the Wellington public. Winsome Shepherd and Walter Cook argue that the Botanic Garden and its history is significant: 'through their survival in association with our own development as a people, they acquire an emotional and symbolic significance, expressing certain attitudes that we hold about our past, our environment and the things we value in it'. The Wellington Botanic Garden is 'public in its creation and the purposes it serves' ${ }^{11}$

The Wellington Botanic Garden was founded on British ideas of a colonial botanic garden that would support plant trials, acclimatisation, research into native plants and also to be a place for contemplation and learning. The Botanic Garden demonstrates many elements of Victorian philosophy and values, such as the Romantic Movement. The Botanic Garden is often described by nineteenth century writers in terms of the sublime and savage, key terms in the Romantic Movement and romantic landscape painting. The native bush created an image of the 'forest primeval' and the New Zealand Cyclopedia described the Garden as a wilderness. The Botanic Garden also appealed to the idea of the exotic. The pine plantations of the 1870s were considered a romantic symbol. Interest in new plants was also key to the Botanic Garden, as science was a major pastime and interest of the 'modern man'. ${ }^{12}$ The rare and unusual species found in Hector's Teaching Garden made the Teaching Garden a popular attraction. ${ }^{13}$ As a garden, the Wellington Botanic Garden evolved as it is not "from any grand architectural design but from a series of pragmatic responses to the site, climate, horticultural taste, and a variety of

\footnotetext{
9 Winsome Shepherd, 'The Wellington Botanic Garden: an Important Historic Garden', Royal New Zealand Institute of Horticulture Annual J ournal, 12, 1984, pp. 109-111.

${ }^{10}$ Mike Oates, personal communication, 12 August 2003.

${ }^{11}$ Winsome Shepherd and Walter Cook, The Botanic Garden Wellington, A New Zealand History 1840-1987 (Wellington: Millwood Press, 1988), p. 213.

12 Shepherd and Cook, pp. 229-231.

${ }^{13}$ Shepherd and Cook, p. 231.
} 
other uses and demands operating at different time over the last one hundred and [thirty] years'. ${ }^{14}$

The Botanic Garden has a rich past which is connected to New Zealand as a whole, the Wellington region, the central Government, the New Zealand Institute, the sciences in New Zealand and the many generations of visitors over its 134 year history. At the conclusion of their history of the Wellington Botanic Garden, Shepherd and Cook remark, 'The Garden now has a past. It is a rich varied past intimately linked to the development of the city and country since 1840 . Such a past has to be acknowledged, and such a past becomes part of the future of the Botanic Garden' . ${ }^{15}$

The Botanic Garden today has three main emphases: promoting the appreciation of plants and gardens in general; conserving and interpreting the historic and natural features of a heritage landscape; and providing for public recreation in a mixed garden environment. ${ }^{16}$ The Botanic Garden's Management Plan includes provision for the cultural environment in the form of built heritage, planted and introduced features. The Management Plan also provides for the tall tree framework and the natural heritage of the indigenous and native ecosystems such as native bush remnants and wildlife. ${ }^{17}$ The strategic vision for the four botanic gardens is 'to enhance people's awareness of plants and their environment, provide appropriate recreational opportunities, and manage and protect out diverse cultural and natural heritage'. ${ }^{18}$

The Botanic Garden also has a strong educational focus, and plans to review its plant collection in order to best serve public interest and promote 'excellence in specialised areas'. Staff are planning to create an interpretive plan of the Botanic Garden, as this has already been done for the Bolton Street Memorial Park. A consistent sign guide will be implemented. The Botanic Garden Management Plan also intends to develop practical demonstrations further, as well as promoting guided tours. The Botanic Garden's strategic goals also include supporting and conducting research, providing formal and informal education and developing and enhancing interpretation. The Botanic Garden Management Plan also suggests that a wide range of appropriate recreational uses be encouraged in the Garden. A range of public events is also to be explored. The walkways are to be maintained in a way suitable for a range of interests and abilities. ${ }^{19}$

The Botanic Garden is an important habitat for many New Zealand birds and reptiles. Fantail, greywarbler and tui are the main native bird species found in the Botanic Garden. The Botanic Garden is a key breeding habitat for greywarblers, and kingfishers can be found in the Garden in summer. Kereru are also found in the Botanic Garden. Six varieties of protected skink are found in the Botanic Garden and Bolton Street Memorial Park. ${ }^{20}$

The natural and cultural heritage of the Wellington Botanic Garden is important to interpretation of the Garden as central to Wellington's history. The Wellington City District Plan defines heritage as 'aspects of the natural and cultural environment

\footnotetext{
${ }^{14}$ Shepherd and Cook, p. 349.

15 Shepherd and Cook, p. 355.

${ }^{16}$ Wellington City Council, p. 7.

${ }^{17}$ Wellington City Council, p. 7.

${ }^{18}$ Wellington City Council, p. 23.

${ }^{19}$ Wellington City Council, pp. 7-8, 23.

20 Wellington City Council, pp. 12-13.
} 
that are inherited from the past, that provide a context for the present and that shape the future. Heritage provides the community with a sense of continuity and the ability to identify with their City through evidence of its past in the existing environment'. ${ }^{21}$

${ }^{21}$ Wellington City Council, p. 26. 


\section{History of the Wellington Botanic Garden}

\section{Maori}

Maori have been present in the Wellington region since about 1125 . Kupe was the first figure to reach Wellington, and later various tribes, including Ngati-tara and Ngati-Mutunga came to the Wellington area. ${ }^{22}$ Before 1800 Wellington Harbour was inhabited by Ngait-turoto for many generations. However, '[d]uring the first two decades of the $19^{\text {th }}$ century the west side of Te Whanganui-a-Tara (Thorndon to Ngauranga) was deserted'. Whanganui-a-Tara had a turbulent time from 18191836, as the area exchanged hands twice, and was invaded six times. ${ }^{23}$

Ngati Tama settled at Tiakiwai, near the northern end of Tinakori Rd in about 1824. There was a total withdrawal of the Ngati Ira from Whanganui-a-Tara in the late 1820 s, as relationships between Maori soured. ${ }^{24}$ From the early $1830 \mathrm{~s}$, Te Ati Awa became the dominant peoples. ${ }^{25}$ Ballara summarises the occupation of Whanganui-a-Tara as 'a gradual, untidy affair, a series of short sharp clashes and consequent occupation readjustments as Ngati-Ira gradually conceded more territory'. ${ }^{26}$ However, Ballara goes on to state that '[i]t was clear that both push and pull factors were inducing the populations of Te Whanganui-a-Tara and Wairarapa to abandon their territories to the Taranaki invaders. In the case of the harbour, the change was to be permanent' ${ }^{27}$

According to interpretive panels at the Wellington Botanic Garden, cultivations at Polhill and Omaroro 'were certainly the cultivations supporting the Maori communities at Pipitea, Kumutoto and Te Aro. It is estimated that between three to five hundred were living in these areas' ${ }^{28} \mathrm{~A}$ map of the parcel of land returned to Kumutoto Maori by the McCleverty Awards shows cultivation near the current Cable Car/Upland Road area. ${ }^{29}$ Pipitea Stream, which runs through the Botanic Garden, was an important source of fresh water and cultivation supplies. ${ }^{30}$

\section{European Settlement}

Settlers to the New World wanted to avoid the problems of cities in the Old World, and so town planning was an important part of settlement in New Zealand. Town planners aimed to avoid the narrow allies and courts which often became slums in Britain. Instead, New World cities were to be open, with plenty of space and suburbs. ${ }^{31}$ In Britain there was a belief that cities were inherently dangerous, because of their moral laxity, close-quarters living and slums which spread disease.

\footnotetext{
22Paul Tritenbach, Botanic Gardens and Parks in New Zealand: An Illustrated Record (Auckland: Excellence Press, 1987), p. 66; Angela Ballara, 'Te Whanganui-a-Tara: phases of Maori occupation of Wellington Harbour c. 1800-1940', in David Hamer and Roberta Nicholls (eds), The Making of Wellington 1800-1914 (Wellington: Victoria University Press, 1990), pp. 9, 12, 13.

${ }^{23}$ Ballara, p. 9.

${ }_{24}^{4}$ Ballara, p. 18.

${ }^{25}$ Gavin McLean, Wellington: The First Years of European Settlement 1840-1850 (Auckland: Penguin, 2000), p. 13.

${ }^{26}$ Ballara, pp. 19-20.

27 Ballara, p. 21.

${ }^{28}$ Interpretive panel, Treehouse Interpretive Centre, Wellington Botanic Garden.

${ }^{29}$ Wellington City Council, p. 13.

30 McLean, p. 17.

31 David Hamer, New Towns in the New World: Images and Perceptions of the NineteenthCentury Urban Frontier (New York: Columbia University Press, 1990), pp. 65, 68-69.
} 
Settler cities were doubly problematic because of their youth and instability: they were often described as chaotic. ${ }^{32}$ Because settler towns and cities had only recently been carved out of the landscape of native bush, there was often a fear of the wilderness, and so nature had to be tamed in order for towns to live harmoniously within a wild country. According to Hamer, as cities became more populated and developed industry, this element of the natural was lost. Instead, public parks and gardens, and provisions such as the Town Belt became necessary. ${ }^{33}$ Provision for a botanic garden was included in Mein Smith's surveys of Wellington for the New Zealand Company in 1839. The Botanic Garden was part of the Town Belt, and was established as a 12 acre block, which was increased to 13 acres in 1868. ${ }^{34}$

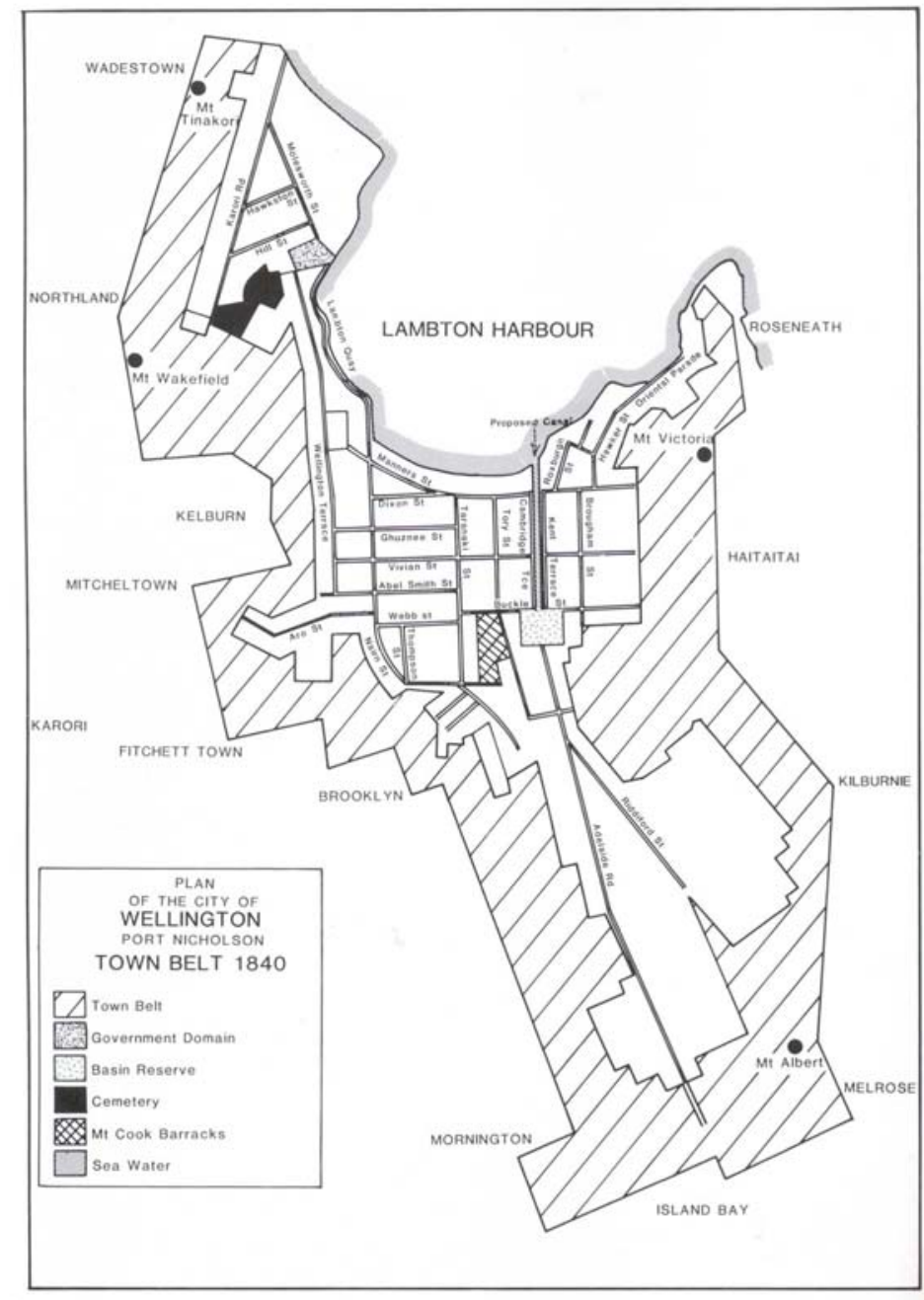

Plan of the Town Belt, 1840 [Source: Shepherd and Cook, p. 18].

32 Hamer, pp. 122, 126.

33 Hamer, pp. 191-193, 199.

${ }^{34}$ Shepherd and Cook, pp. 17, 19. 
On 14 J anuary 1840, New Zealand was annexed to New South Wales, and William Hobson became the Lieutenant Governor. He issued the Land Titles Validity Proclamation, and declared that all land purchases prior to annexation would be investigated. Hobson hoped to improve race-relations by showing that the government would be 'more responsible and regular' in its land purchase. He anticipated that Maori would be able to sell their land 'without distress or inconvenience to themselves'. ${ }^{35}$

William Spain was appointed as Commissioner by the Secretary of State for Colonies. He arrived in New Zealand in late 1841, and was to investigate both the claims of the New Zealand Company and claimants against the New Zealand Company. 116 cases were referred to Commissioner Spain. ${ }^{36}$ Spain recognised that the reserves put aside by the New Zealand Company for Maori were inappropriate, as they were hilly or too far from potato cultivation areas. Spain agreed to Wakefield's proposal to compensate Maori with surplus supplies from ships, however Spain felt that the settlement had to be made quickly. Spain felt that giving land back to Maori was 'impracticable' as he thought that Maori would not consent to selling the land at pre-settlement value. Spain felt that this was a case of compensation not land return. ${ }^{37}$ However, Spain did exempt pa, burial grounds and cultivation sites from the sale. ${ }^{38}$ According to Tonk, 'Spain ruled that the Maori would give up their lands to the Company in exchange for immediate compensation'. Compensation was paid to various iwi in the Wellington area, including the Te Aro Pa (£300), Pipitea Pa (£200), Kumutoto Pa (£200) and Tiakiwi $(£ 30) .{ }^{39}$ Tiakiwai is modern Thorndon. ${ }^{40}$

Colonel G.W.A. McCleverty was appointed to 'direct the survey and selection of the lands which were due to the Company'. In 1847 he awarded 44 urban sections and 2868 rural acres to individual hapu. In 1847 he also made a series of exchanges with Maori, where Maori gave up cultivation on European land in return for property which comprised of 'original Maori reserves, parts of the town belt, Hutt Valley lands.... ${ }^{41}$ One of these exchanges was 52 acres, 2 roods, and 37 perches of Town Belt adjacent to the original 13 acres of the Botanic Garden Reserve. This was known as the Kumototo Block and was later to become the Wesleyan Reserve. It is not known if Maori used this land for cultivation in the three years they owned it. It was sold back to the Government in 1851 for $f 150$ and some land in the Hutt Valley. In 1852, the land was given to the Wesley Church Mission. ${ }^{42}$ By 1865, the land had still not been used by the Mission so it was taken back by the Government and was earmarked as a public park. ${ }^{43}$

\footnotetext{
${ }^{35}$ Rosemary Tonk, "'A Difficult and Complicated Question": The New Zealand Company's Wellington, Port Nicholson, Claim', in David Hamer and Roberta Nicholls (eds), The Making of Wellington 1800-1914 (Wellington: Victoria University Press, 1990), p. 35.

36 Tonk, p. 36.

${ }^{37}$ Tonk, pp. $50-51$

38 Penny Ehrhardt, Te Whanganui-a-Tara Customary Tenure 1750-1850 Waitangi Tribunal research series no. 3 (Wellington: Waitangi Division, Dept of J ustice, 1993), p. 34.

39 Tonk, pp. 56, 58.

${ }^{40}$ Ehrhardt, p. 20.

${ }^{41}$ Tonk, p. 59.

42Shepherd, Winsome, 'Heritage, Botanic Garden, Volume I', unpublished, 1992. Held at Wellington Botanic Gardens Reference Library, pp. 112, 116; Shepherd, Winsome, Wellington's Heritage Plant, Gardens and Landscape (Wellington: Te Papa Press, 2000), p. 217.

${ }^{43}$ Shepherd, Wellington's Heritage, p. 218.
} 


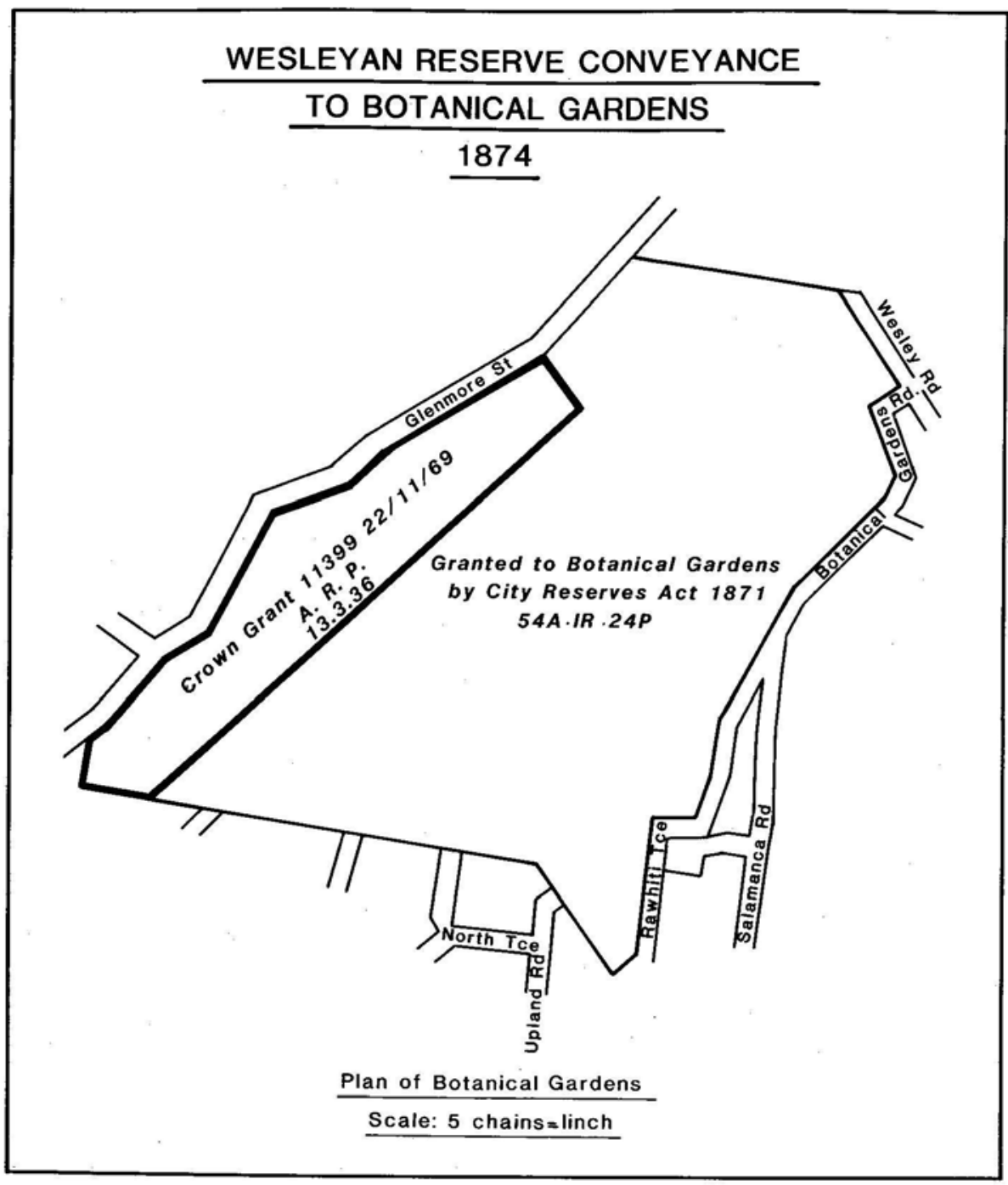

The Wesleyan Conveyance to the Botanic Garden, 1874 [Source:

Shepherd and Cook, p. 26].

The Wellington Horticultural Society was founded in 1841, and regularly staged exhibitions despite the problems faced by the new colony. In 1851 the Horticultural Society approached the Colonial Secretary for a Crown Grant for the land designated as a Botanic Garden Reserve, and named a committee. The land was declared as Botanic Garden Reserve, however no further action was taken for another five years. ${ }^{44}$ The Botanic Garden Reserve was protected by the Crown and was not used as grazing land. However, there were threats to the Town Belt and Botanic Garden Reserve in the form of squatters who were burning scrub and even building cottages. There was also loss of Reserve and Town Belt land to churches and cemeteries. ${ }^{45}$

${ }^{44}$ Shepherd and Cook, pp. 20-1.

${ }^{45}$ Shepherd and Cook, pp. 22-23. 


\section{Establishment of the Botanic Garden: the Botanic Garden Board}

By 1867, there was a growing interest in the Botanic Garden reserve. Dr. James Hector, who had recently moved to Wellington and was a Government consultant on scientific matters, was asked to look over the Botanic Garden Reserve. Dr. Hector recommended it as a good site, with plenty of still and running water, good soils and good access and position. He also remarked that the site was very narrow, and suggested that the Wesleyan Reserve, which was already on its way to becoming a public park, could be consolidated with the twelve acres of Botanic Garden Reserve. Dr. Hector imagined a botanic garden which would be both a public park and 'a Garden for botanical, horticultural and acclimatisation purposes'. Hector estimated that it would cost $£ 2400$ to establish the Botanic Garden, by building greenhouses, potting sheds, manager's office, paths, bridges and fences. He also estimated that it would cost about $£ 1000$ per year to upkeep the Garden. ${ }^{46}$ Mr Gisborne, the Colonial Under Secretary, agreed to Dr. Hector's suggestion of setting apart the Botanic Garden Reserve and part of the Wesleyan Reserve. A year after Dr. Hector had first inspected the Botanic Garden Reserve, the Public Domain Act was passed, and the Botanic Garden Reserve became a Public Domain. In October 1868, Dr. Hector was given authority over the land. By February 1869, Dr. Hector had established a nursery and was receiving seeds from Kew. ${ }^{47}$

\section{A Colonial Botanic Garden}

Establishing the Botanic Garden as a kind of 'Central Depot for botanical and acclimatising purposes' was more than Dr. Hector could do on his own. ${ }^{48}$ This kind of central store for botanical material would benefit the whole colony and would make the Wellington Botanic Garden a Colonial Botanic Garden. In 1869 Alfred Ludlam, a Member of Parliament and keen horticulturalist, introduced the Wellington Botanic Garden Bill to Parliament. The Bill was passed, and a Crown Grant was executed, giving control of the Botanic Garden to the Governors of the Botanic Garden, being the Governors of the New Zealand Institute. f376.7.6 held by the New Zealand Institute in Trust for the provision of a garden was given to the new Botanic Garden Board. The Government did not contribute, and did not establish future funding. ${ }^{49}$

The 73 acres, 1 rood and 22 perches of Wesleyan land were purchased for $£ 3500$. Hector applied to fence 32 acres of the Wesleyan land, and this became part of the Botanic Garden. In 1874, a further 20 acres were conveyed to the Botanic Garden, meaning that the Garden was now 68 acres, 1 rood and 20 perches in size. In 1877, some cemetery land was being supervised (but not leased) to the Garden, so the acreage stood at 77 acres, 1 rood and 10 perches. ${ }^{50}$

From 1869, the Botanic Garden was governed by the Botanic Garden Board, which was drawn from leading politicians and scientists in the colony. The Board envisioned that the Botanic Garden would meet three needs of the Colony: to act as a trial ground for examining the economic potential of plants; as a place for the scientific study and collection of plants; and as a public place. ${ }^{51}$

\footnotetext{
${ }^{46}$ Shepherd and Cook, p. 24.

${ }^{47}$ Shepherd and Cook, pp. 24-25.

${ }^{48}$ Stafford in Shepherd and Cook, p. 25.

49 Shepherd and Cook, p. 25.

50 Shepherd and Cook, pp. 25-27.

${ }^{51}$ Shepherd and Cook, p. 33.
} 
The Botanic Garden Board was made up of the same people as the New Zealand Institute Board. Five Governors of the Colony were members of the Board, and several Premiers and Superintendents of Wellington served on the Botanic Garden Board. The first Board meeting was held on 28 September 1869. ${ }^{52}$

Once the Crown Grant was issued, work began on fencing and building paths in the Botanic Garden. ${ }^{53} 1870$ was a busy year, as roads and paths were established in the Garden, and the battle against gorse began. By 1876, the Board had spent $f 270.3 .4$ on fencing, $£ 103.11 .4$ on paths, $£ 185.12 .6$ on buildings and $£ 147.1 .4$ on seats. ${ }^{54}$ However, formal entrance gates were not erected until 1878, when a picket fence and gate were built for the cost of $£ 69 .{ }^{55}$

\section{Dr. J ames Hector}

Dr. James Hector was a qualified medical doctor from Edinburgh. He came to New Zealand in 1862 after being appointed to establish the Otago Provincial Geological Survey. He immediately began collecting geological specimens, and in 1865 a New Zealand geological exhibition was held in Dunedin, showcasing fossil, rock and mineral collections from around the country. That year Hector was asked to establish a Geological Survey for New Zealand in Wellington. By the end of 1865, he had arrived in Wellington, along with all his staff from the Dunedin Geological Survey. An Act of Parliament established the New Zealand Institute in 1867, and Dr. James Hector was made Director of the Institute, the Colonial Museum and the Colonial Laboratory. Hector was also in charge of the Colonial Observatory, the Meteorological Department and the Standard Weights and Measures. ${ }^{56}$ As there were few scientists in the Colony, the Government relied on Hector to give advice on subjects as diverse as

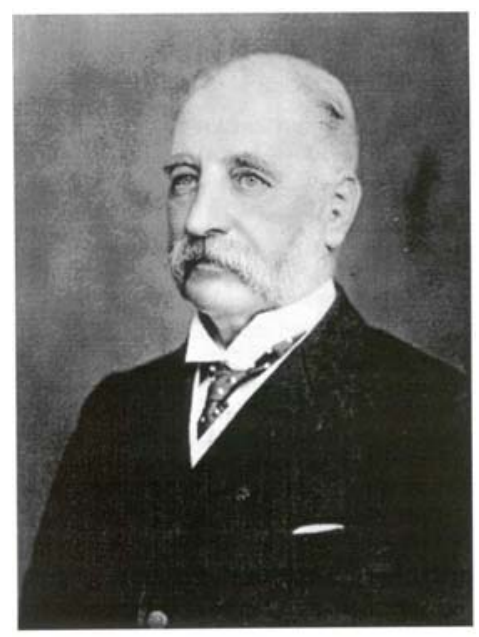

Sir J ames Hector [Source: Alexander Turnbull Library, MNZ1161-1/2]. olive oil and coal. Hector's dominance was known as 'Hectorian centralism' because of his wide influence over every aspect of science in New Zealand. ${ }^{57}$

\section{The First Keepers}

David Hall, owner of the cottage built on Wesleyan land (please see entry on Director's Residence) offered himself as keeper to the Botanic Garden in 1869, and acted as such until William Bramley was hired as Keeper/gardener in 1870. The cottage was bought from Hall, and Bramley lived there until 1876 when the Keeper's Cottage was built on the Serpentine Way. Under Hall's stewardship of the Botanic Garden, various conditions were imposed upon users of the Garden: animals were forbidden to roam the Garden; people were prohibited from cutting wood or damaging plants; and trespass was also forbidden. Horses and cows were

\footnotetext{
52 Shepherd and Cook, pp. 36-38.

${ }^{53}$ Shepherd and Cook, p. 47.

${ }^{54}$ Shepherd and Cook, p. 50.

55 Shepherd and Cook, p. 68.

${ }^{56}$ Shepherd and Cook, p. 33-37.

57 Shepherd and Cook, p. 40.
} 
quite often found grazing on Botanic Garden land. ${ }^{58}$ Bramley took over as Keeper on 23 September 1870, and was paid $f 80$ per annum. His wages increased to $f 100$ in 1872. Bramley remained Keeper until 1889, when he retired. He was replaced with George Gibb, who took over the position on 4 October 1889. Gibb was paid f7.10.0 per month, and remained as Keeper until 1901. Towards the end of Bramley's term as Keeper, he became known as the Curator of the Botanic Garden. ${ }^{59}$

\section{Problems}

Gorse was a constant problem for the under-funded Botanic Garden. In 1881-2, 19 acres of gorse were cleared at a cost of $f 42$. The gorse was affecting young trees and was becoming a fire risk. With an annual income of less than $f 200$, gorse control became a problem for the Botanic Garden. Gorse was still a major issue by the time of the Vesting Act in $1891 .{ }^{60}$ In an effort to raise funds, sheep were run as an experiment in 1876, and were sold for f13.15. Hay was also sold, and raised f201.4. 6 in ten years. ${ }^{61}$

The Botanic Garden did not receive any regular funding from local government until 1874. The province system was abolished in 1876, so the Botanic Garden received only this funding for only two years. The Botanic Garden also received a proportion of the rents raised from the Town Belt. In 1876 the amount given to the Botanic Garden from the Town Belt rents was only f93.9. The major source of income for the Garden was from plant trials. However, during the recession of the 1880s, the Government withdrew much of its support for plant trials. The Botanic Garden could no longer afford to distribute trees and shrubs for free, and instead surplus plants were sold to raise money. ${ }^{62}$

\section{Acclimatisation and Plant Trials}

The 1869 Botanic Garden Act allowed for the Botanic Gardens to be used for acclimatisation of plants and animals. The first meeting of the Wellington Acclimatisation Society was on 20 April 1871. Acclimatisation Societies aimed to introduce plants and animals that could be of value to the Colony and settlers. Pheasants, fowl and even emus were introduced to the Botanic Garden. Unfortunately, the emus were responsible for 'the wholesale destruction of young plants' and had to be confined. ${ }^{63}$ By 1881, one of the emus had died, and another brought from Blenheim to keep the remaining emu company. At one stage, there were also several monkeys and kiwi at the Botanic Garden. The monkeys regularly caused trouble by escaping and attacking children and terrorising the neighbours' chickens. Newtown Zoo was opened in 1906, and the monkeys and emu were moved to the Zoo. ${ }^{64}$

The Botanic Garden was also used to trial plants as diverse as mulberries, cork oak, olives, beetroot and sorghum. A Colonial Industries Commission was established by Vogel, and began to investigate the economic potential of various plants. The Geological Survey was used to distribute seeds and collect results. However, by

\footnotetext{
${ }^{58}$ Shepherd and Cook, pp. 47-49.

${ }^{59}$ Shepherd and Cook, p. 48.

${ }^{60}$ Shepherd and Cook, pp. 49-50.

${ }^{61}$ Shepherd and Cook, pp. 50-51.

62 Shepherd and Cook, pp. 55-57.

${ }^{63}$ Mantell in Shepherd and Cook, p. 51.

${ }^{64}$ Shepherd and Cook, p. 52.
} 
1885 the Government was unable to finance these projects, and the money that the Botanic Garden needed dried up. Over the ten years from 1870 to 1880, the Botanic Garden earned $f 1000$ for their part in plant trials. ${ }^{65}$

Flax was one of the first plant trials at the Botanic Garden. A quarter acre was put aside in 1870 for the raising of flax. About 21 varieties of flax were grown at the Botanic Garden. As late as 1972 flax from this collection was discovered near the Dominion and Carter Observatories. The Botanic Garden Historic Flax Collection is still an important element of the Garden. ${ }^{66}$

Mulberries were one of the first plant trials at the Botanic Garden. In 1871, the Government gave 150 white mulberry trees to the Garden. It seems that the trees were unsuccessful, and were not given time to mature to produce the leaves needed to feed the silk worms. ${ }^{67}$ The next trial was Spanish cork oak in 1872. Unfortunately, cork oaks take about 25 to 27 years before they are mature enough to produce cork, and then cork can only be stripped and collected every eight years. Some of these cork oaks remain in the Botanic Garden today, and are related to the cork oaks at the Royal Botanic Garden at Kew. ${ }^{68}$

Sorghum was another plant trial at the Botanic Garden. Sorghum, which is used to produce sugar, was introduced to the Garden in 1881 after earlier trials in Tauranga and the Hawkes Bay. Unfortunately, there is no information about how successful the trial was. There were also sugar beet trials at the Garden in 1871 and 1875, but the plants did not yield enough sugar to make any further trials worthwhile. ${ }^{69}$

In 1883, twenty olive trees were planted at the Botanic Garden. An olive oil industry was being considered in the Colony, especially around Auckland. The trees in the Botanic Garden flourished at the time, but do not exist in the Garden today. ${ }^{70}$

The most important plant trial at the Botanic Garden was its extensive conifer trials. One of the rationales for founding the Botanic Garden was to 'form the basis for a system of forest propagation throughout New Zealand', and the raising and distribution of conifer plants became a central role of the Botanic Garden. By 1860, the need for quick growing trees for shelter and timber was growing, and the conifer species of North America, India and J apan seemed to fill this need. The Botanic Garden has some of the country's oldest Pinus radiata. The Botanic Garden also distributed the trees throughout the country. In 1870-1 the first trees were planted in the Botanic Garden, and the Pinus radiata and Cupressus macrocarpa gave the best results. In 1871 the Forest Trees Planting Encouragement Act was passed, which was intended to encourage settlers to plant trees like Pinus radiata by giving a free grant of two acres of wasteland for every acre planted with forest trees. In order to fulfil the Act, the Government had to purchase the trees, and James Hector once again became the distribution point for the seed. The Geological Survey served this function from 1870 to 1884. The Botanic Garden received conifer seed from as far afield as the Himalayas and Mexico, as well as the Royal Botanic Gardens at Kew and Calcutta. Eucalyptus was also imported from

${ }^{65}$ Shepherd and Cook, pp. 85-86.

${ }^{66}$ Shepherd and Cook, pp. 86-87.

${ }^{67}$ Shepherd and Cook, pp. 87-89.

${ }^{68}$ Shepherd and Cook, pp. 89-90.

${ }^{69}$ Shepherd and Cook, pp. 90-91.

70 Shepherd and Cook, pp. 91-92. 
Australia. The last seed was imported from the United States in $1886 .{ }^{71}$ By 1921 , Pinus radiata was one of the country's leading timber species. ${ }^{72}$

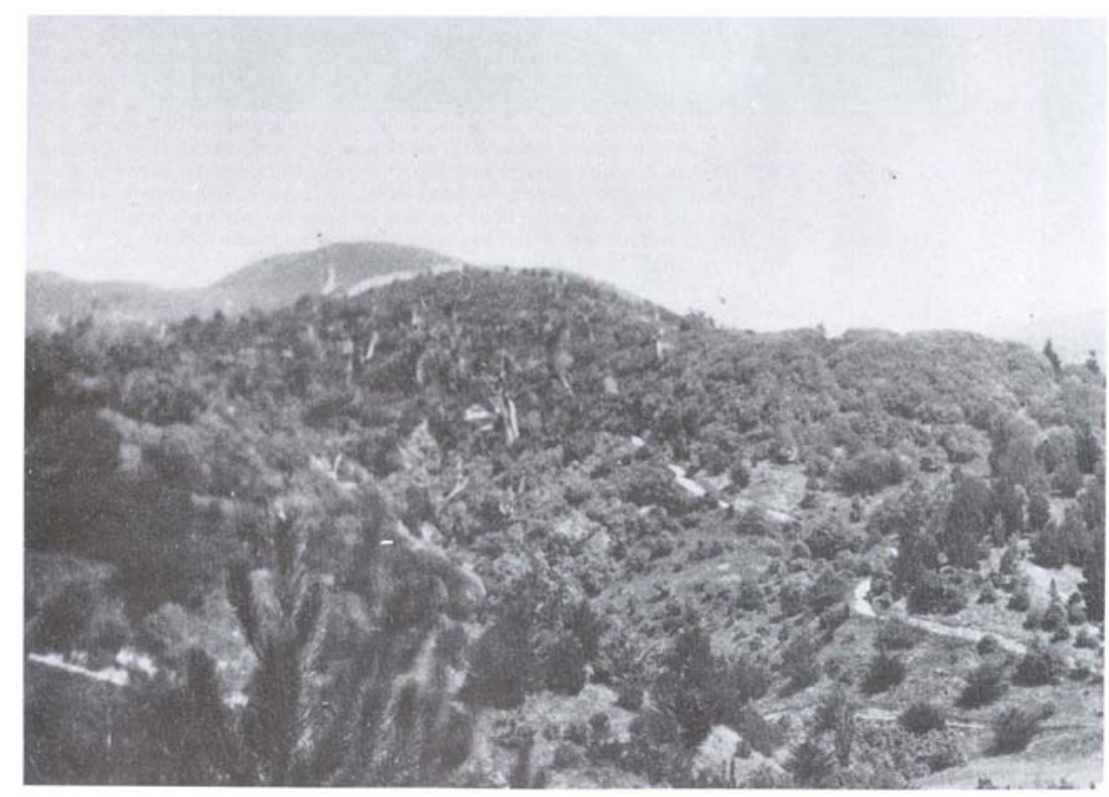

The Botanic Garden, c. 1880, showing native bush and conifers [Source: Shepherd and Cook, p. 72].

\section{Security}

By 1876 William Bramley, the Keeper, was unable to supervise the entire Botanic Garden by himself. He was even injured keeping the peace in 1880. After this incident, a police constable was appointed to the Botanic Garden. Constable Campbell lived in what is now known as the Keeper's Cottage. At the time it was called the Constabulary or the Rangers Cottage, and remained as the Gardens constable's residence until 1898. Constable Gleeson replaced Campbell in 1882. There were still problems with livestock and dogs wandering into the Botanic Garden as late as 1882, as reported by Constable Gleeson. Constable Whelan replaced Gleeson 1890. ${ }^{73}$

\section{The native bush}

When the Wesleyan land was purchased and ceded to the Botanic Garden, some native forest remained in the valleys. The native bush was in 'a fair state of preservation' despite the fact that much of the useful timber had been removed by settlers in the 1840s and 1850s. A reasonable amount of native bush remained in the Garden in 1875, including maire, miro, rimu, totara, kahikatea, rata and teatree. Due to the earlier removal of timber, the remaining native trees needed protection from the wind. In the 1870s, the Botanic Garden Board planted conifers, oaks, Australian blackwood and New Zealand beeches to protect the native bush. In 1891, when the Botanic Garden was vested to the Wellington City Corporation, J ames Hector estimated that one fifth (15 acres) of the Botanic Garden was still in

\footnotetext{
${ }^{71}$ Shepherd and Cook, pp. 95-100, 103.

72 Shepherd and Cook, p. 117.

${ }^{73}$ Shepherd and Cook, pp. 61-65.
} 
bush, with 20 acres in kanuka, 36 acres in plantations and 15 acres in open grass. The Botanic Garden was recognised for its native tree-ferns and shrubs by Dr. Leonard Cockayne, who went on the found Otari Open-Air Museum. ${ }^{74}$

As well as bush native to Wellington, other native plants were introduced to the Botanic Garden. The Board aimed to establish a collection of plants from other parts of New Zealand. The Wellington Philosophical Society donated f50 in 1870 towards collecting and labelling the plants. The labels showed scientific, popular and Maori names for the plants and shrubs. Plants from as far afield as the Chatham and Auckland Islands were introduced, along with kauri, kowhai and cabbage trees. An alpine collection was also begun. Many of these New Zealand plants became the core of Hector's Teaching Garden, which was set out in traditional rectangular beds. The Botanic Garden also sent many native plants and seeds to other botanic gardens such as Kew, J amaica, Washington and Melbourne. ${ }^{75}$

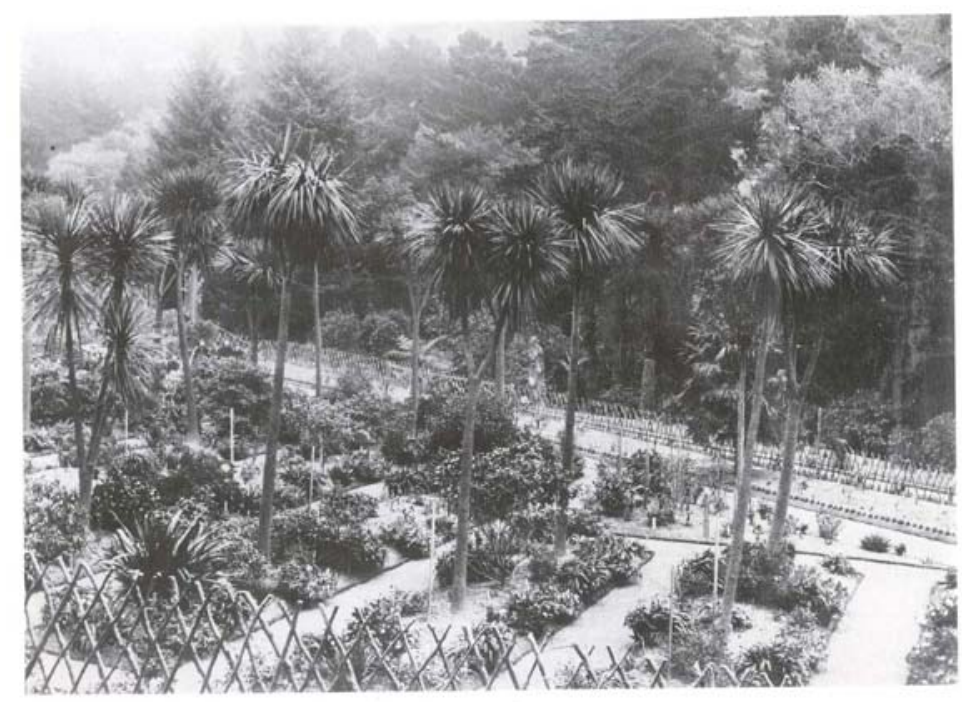

Hector's Teaching Garden, c. 1900 [Source: Shepherd and Cook, p. 80].

Seed that was raised at the Botanic Garden was distributed to other major gardens, as well as private individuals, schools, hospitals, churches and Government House. Wellington Botanic Garden seed was sent all over the country, and the resulting trees can be found in gardens all over New Zealand. ${ }^{76}$

\section{Transporting seed}

The planting done by the Botanic Garden Board included many Old World plants such as magnolias, camellias and rhododendrons. There was strong tradition of exchange between the botanic gardens and acclimatisation societies throughout the world, and the Wellington Botanic Garden received plants from Melbourne, Kew, Queensland, Calcutta and other locations. The successful transportation of seed was through the use of Wardian Cases. It was very difficult to transport seed

\footnotetext{
${ }^{74}$ Shepherd and Cook, pp. 71-79.

75 Shepherd and Cook, pp. 80-82.

${ }^{76}$ Shepherd and Cook, pp. 111-116.
} 
to New Zealand; often the seed would rot, burn, be eaten by rats or be too old for any use by the time it arrived here. In 1829, Nathaniel Bartholemew Ward invented the Wardian Case, which allowed for the transportation of live plants. The Wardian Case was a miniature greenhouse, and tall glass jars filled with water allowed for the plants to survive without watering for months at a time. However, many plants were lost on their way to New Zealand, usually because of the great distance between Britain and New Zealand, and because the Wardian Cases were poorly packed or managed during the voyage. ${ }^{77}$

\section{The last years of the Botanic Garden Board}

By 1885 the Botanic Garden was sorely in need of income. Government had withdrawn its funding and the Botanic Garden received barely enough from the Town Belt rents to pay Mr. Bramley's salary, let alone maintain the Garden. Upkeeping the fences and controlling gorse were the main problems that the Board had to face. Some of the fences were 15 to 25 years old, and were no longer secure. In 1887, a fire broke out in the Botanic Garden, destroying various outbuildings, including tool sheds and also damaging plants. There was little money to rebuild and replace the lost tools and buildings. There was growing public concern that the Botanic Garden was falling into disrepair, and it was first suggested in 1887 that

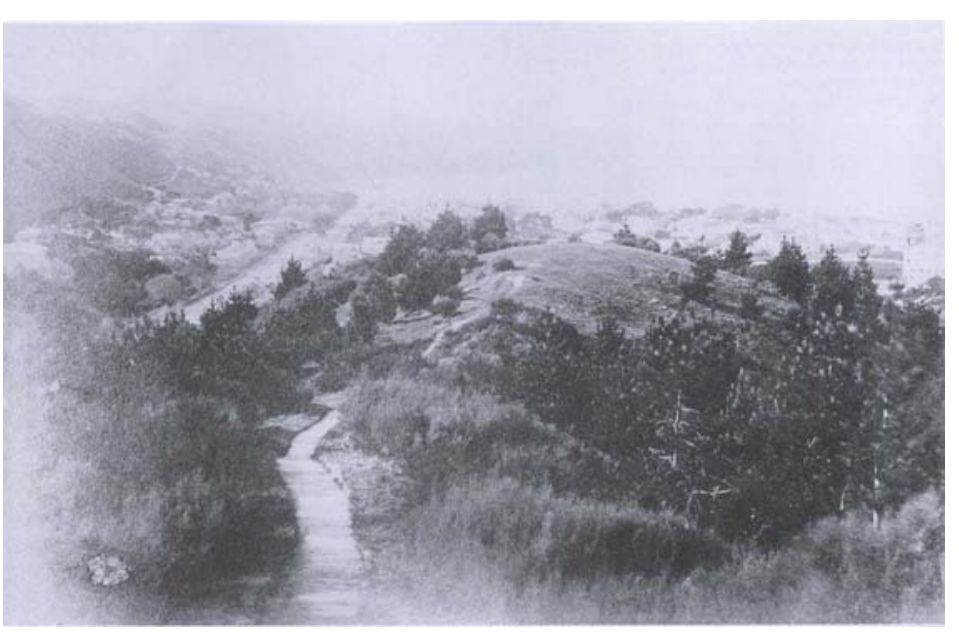

Looking east from today's herb garden, the Botanic Garden, c. 1885 [Source: Shepherd and Cook, p. 134]. the Botanic Garden management be given to the Wellington City Corporation. The Botanic Garden Board were unanimously against the proposal. They feared that the Corporation would do 'mischief' to the Garden, and argued that the Botanic Garden was an asset belonging to the Colony, as demonstrated by the plant trials and research undertaken in the Botanic Garden. They were also worried that the Wellington City Corporation did not have the expertise to deal with the different functions of the Botanic Garden. The Board also emphasised the need to maintain the original 13 acres set aside by Wakefield as a botanic garden, and the possibility of constructing an observatory on land in the Botanic Garden. Evidence related to the Bill was discussed at the Local Bills Committee in September of 1891. The City Corporation reported that it had "no intention to level or destroy any of the Garden' and also promised to eradicate gorse as it was already doing on the Town Belt. In 1891, the Botanic Garden Vesting Act was passed. The Act included provision for an observatory and 'the requirement that the original thirteen acres be maintained as a Botanic Garden in perpetuity'. ${ }^{78}$

\footnotetext{
77 Shepherd and Cook, pp. 137-143, 146-151.

78 Shepherd and Cook, pp. 169-175.
} 
Winsome Shepherd sums up the work of the Botanic Garden Board thus: 'the Board in its twenty-two years developed a well balanced Garden with an area devoted to botany, fifteen acres in natural bush, collections of camellias and rhododendrons, magnolias, exotic trees, ferns and of course, the extensive pinetum. The only features missing were wide expanses of lawn and long vistas'. ${ }^{79}$

\section{The Vesting Act: the Wellington City Corporation/Council}

The Botanic Garden Board had feared that the Wellington City Corporation did not have enough experience in dealing with horticultural matters. The Corporation had been managing the Town Belt since at least 1876, but had not shown great skill, a legal loophole allowing gorse to spread on land the Corporation rented to tenants. Tree planting in the reserves maintained by the City Corporation had also been neglected. However, by 1891 the Corporation was better established and better financed, and had more experience in dealing with the Town Belt. The Botanic Garden was already well established, and the City Corporation inherited two experienced staff, including Keeper George Gibb. ${ }^{80}$

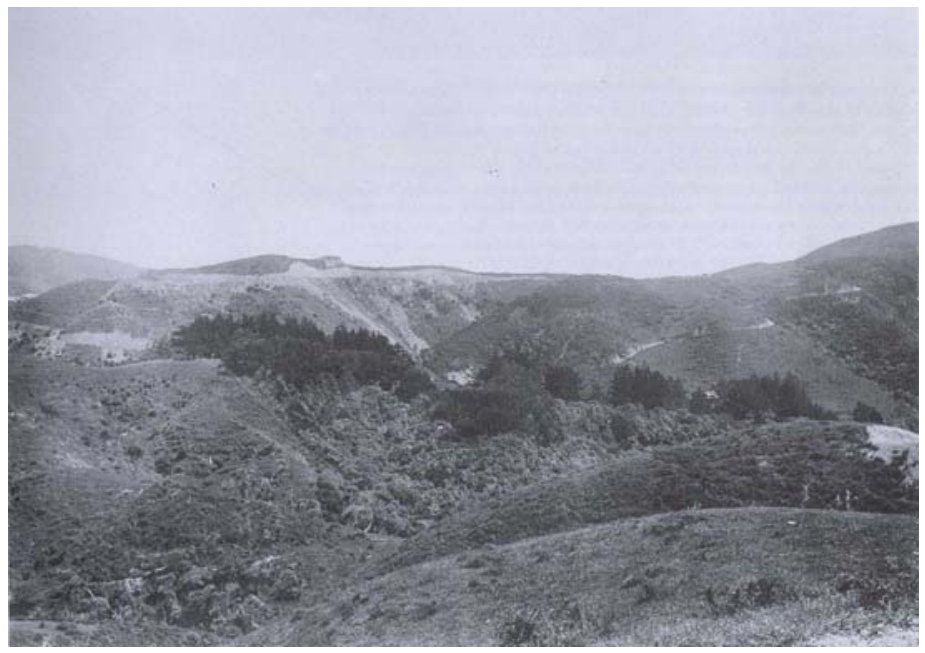

The Botanic Garden 1902, showing conifers and bush

[Source: Shepherd and Cook, p. 73].

\section{The Romantic Movement}

The City Corporation regarded the Wellington Botanic Garden as 'the jewel in the crown' of Wellington. The Botanic Garden stood out against the arid hills of Wellington and was described in 1897 by the New Zealand Cyclopedia as the only redeeming feature of Wellington city. ${ }^{81}$ The Botanic Garden was also popular with the public, being a respite from the city and the wind. It was a popular spot for a walk and a place for sightseers and tourists. The Botanic Garden reflected the values of the Romantic Movement popular in the latter third of the nineteenth century. Nineteenth century contemporaries describe the Botanic Garden as a 'wilderness' and as having a 'rugged beauty'. The pines were exalted for their wildness. ${ }^{82}$

\footnotetext{
${ }^{79}$ Shepherd and Cook, p. 155.

${ }^{80}$ Shepherd and Cook, pp. 221-226.

${ }^{81}$ Shepherd and Cook, p. 229.

82 Shepherd and Cook, p. 230.
} 


\section{The First Ten Years}

The excellent management of the Botanic Garden under the Botanic Garden Board, despite the lack of funds, meant that the Garden was well established and running well, except for the essential gorse management and fence repair. The City Corporation maintained the status quo for a time, and 'there was no major physical change to the appearance of the Garden in the next ten years' to $1901 .{ }^{83}$ However, the intention of the Garden had shifted from a place for scientific research to a place for public recreation. From 1895 onwards, public demand grew for the Garden to be developed as a public pleasure ground. The City Corporation maintained tight controls over public use of the Botanic Garden, with access to the Teaching and Camellia Gardens restricted, and visitors were expected to stay off the grass. ${ }^{84}$

\section{Security}

Under the City Corporation, security at the Botanic Garden was still an issue. There were calls for Botanic Gardens staff to be made special constables in 1893, a uniformed policeman was put on patrol in the Garden in 1894 and in 1907 and 1908 there were calls to have a plainclothes police officer on duty in the Gardens. Botanic Garden staff were indeed made special constables in 1904, and the plainclothes officer was installed in 1908. As staff numbers in the Garden increased and as scrub was cut away, security became less of an issue in the Gardens. ${ }^{85}$

\section{The Public's Garden}

With the completion of the Cable Car in

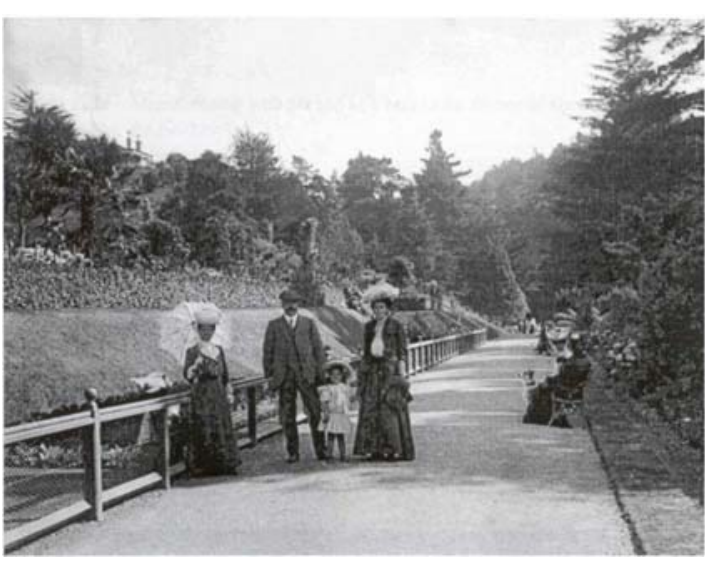

A day out at the Botanic Garden, 1907 [Source: Alexander Turnbull Library, PA1-0-229-3].
1902, access to the Botanic Gardens became easier, and the Gardens an even more popular place to visit. With the building of public conveniences and a tearoom near the Cable Car in 1904, the Botanic Garden became the perfect place for an outing. Electrified trams reached the Main Gates of the Botanic Garden in 1904, enabling even easier access. ${ }^{86}$

In 1904, music became a common element of the Botanic Garden, especially on Sundays. In 1907 the Band Rotunda was built, and became a popular place for entertainment. This continues today at the Sound Shell and the Dell in the Summer City programmes. ${ }^{87}$

\footnotetext{
83 Shepherd and Cook, p. 232.

${ }^{84}$ Shepherd and Cook, pp. 232-233.

85 Shepherd and Cook, pp. 241-242.

${ }^{86}$ Shepherd and Cook, p. 237.

87 Shepherd and Cook, p. 245.
} 
The Botanic Gardens gained its first children's playground in 1905 under George Glenn, Keeper of the Garden from 1901-1918. Another playground was constructed at Anderson Park in 1927, and was shifted to the site of the original playground in $1934 .{ }^{88}$

Under George Glen more of the Garden was opened to the public. The location of the Cable Car meant that new routes through the Garden were developed, and Glen opened up nurseries along these new routes in response to public interest. The pines which filled the Main Garden were cleared from 1902 to 1906 and the area replanted. Glen subscribed to the idea of the 'horticultural zoo' and many specimens were kept behind lattice fences or wire netting. However, Glen established popular bedding displays and events. ${ }^{89}$ The remodelling of the Main Garden continued under J.G. MacKenzie, Director of Parks and Reserves from 1918 to 1947. During his time in office, the Botanic Garden saw many large-scale changes such as the completion of the Anderson Park extension and the development of the Magpie and Glenmore Lawns. ${ }^{90}$ MacKenzie also removed some of the fences and padlocks which had characterised the Garden since the Board's time. MacKenzie also planted many of the plants best known in the Garden today, such as magnolias and the three phoenix palms in the Main Garden. MacKenzie was fond of bedding displays, and continued Glen's efforts by introducing large displays of spring bulbs and more formal beds shaped like hearts, scrolls and circles. ${ }^{91}$

\section{The Lady Norwood Rose Garden}

The idea for a rose garden arose in 1948 and work began in 1950. Director of Parks and Reserves Edward Hutt conceived of and probably designed the rose garden, based on traditional formal parterre. The Lady Norwood Rose Garden was completed in 1953 and the pergola added in 1961. The Rose Garden was named after Lady Norwood in recognition of the Norwood family's service to the city. The fountain which stands in the centre of the garden was given to the city by the Norwood family in 1977 to replace the fountain originally donated by Lady Norwood in 1956. The Norwood family also gifted the funds for the creation of a waterfall, pond, brick shelter and path near the Meteorological Office in $1971 .{ }^{92}$

\section{Horticultural training at the Botanic Garden}

The Botanic Garden has also acted as a horticultural training ground. J.G. MacKenzie was a supporter of the New Zealand Institute of Horticulture and its Diploma system, and hoped that the Botanic Garden would become a training place for New Zealand gardeners. However, the Depression intervened, and Botanic Garden staff had to gain their diplomas through technical colleges. The Botanic Garden has had a strong apprentice programme since the Second World War. Women were first employed as gardening staff at the Botanic Garden in the 1950s. By 1959, the diploma or trade certificate was compulsory for apprentices and the number of qualified staff increased. Under Ray Mole, lectures and field days were introduced for apprentices. ${ }^{93}$

\footnotetext{
${ }^{88}$ Shepherd and Cook, p. 250; Wellington City Council, pp. 86-87.

${ }^{89}$ Shepherd and Cook, pp. 253-256, 284.

${ }^{90}$ Wellington City Council, pp. 14-15.

${ }^{91}$ Shepherd and Cook, pp. 262- 266, 284.

92 Shepherd and Cook, pp. 288, 294.

${ }_{93}$ Shepherd and Cook, pp. 297-306.
} 


\section{Recent history}

The Wahine Storm of 1968 did a great deal of damage to the Botanic Garden. Many old trees were destroyed or damaged to the extent that they had to be removed. However, it meant that many areas of the Garden could be redeveloped and replanted. The storm meant that light and openness could be brought into areas of the Garden which were formerly overgrown or cramped. ${ }^{94}$

In 1965, Ian Galloway became Director of Parks and Reserves. Under Galloway, visitor and staff facilities were improved, and the Norwood donation of a waterfall and pond were made. The herb and succulent gardens were also established during this time. In 1979, Galloway also instigated the Summer City festival which is still very popular today. Ian Galloway died in 1986, and Richard Nanson took over as Director. Nanson initiated the Centennial of City Council management of the Botanical Garden, as well as establishing the Friends of the Botanic Garden. In 1991 the Treehouse Interpretive Centre was built next to the old Director's Residence. The Interpretive Centre is used as a visitor information centre, education centre, staff offices and as the New Zealand head office of the World Wide Fund for Nature. In 1991, Mike Oates became Curator of the Botanic Gardens of Wellington, overseeing all botanic gardens in Wellington. Under Mike Oates the Garden has seen the redevelopment of the Duck Pond, the establishment of the Botanic Gardens of Wellington Advisory Board as well as the redevelopment of the children's playground.

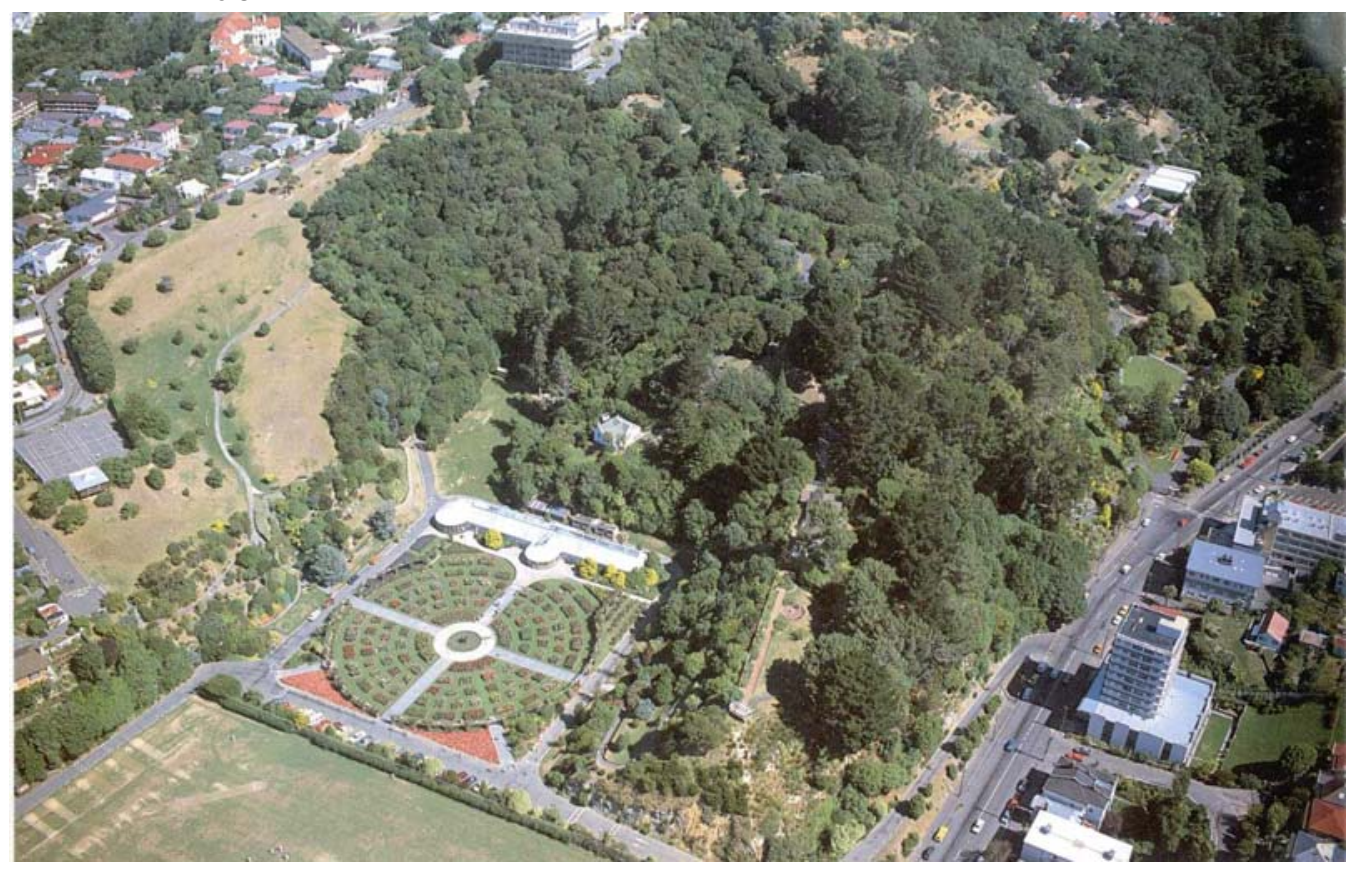

Aerial view of the Lady Norwood Rose Garden, the Herb Garden and native bush [Source: Shepherd and Cook, p. 206].

${ }^{94}$ Shepherd and Cook, pp. 307-309. 


\section{The Gardens Battery: military use}

Land put aside under the 1891 Botanic Garden Vesting Act was used by the Government as a gun battery from 1896. Government workers entered the observatory site in J anuary 1896 without proclamation, and began to excavate for the gun emplacement. After the City Corporation complained about the Government's actions, the 4.5 acres of land were proclaimed as necessary for defence purposes and work continued. The gun battery was built to protect Wellington from a naval attack by Russia. Harbour defences were also built in Lyttleton, Dunedin and Auckland. There were four other batteries built in Wellington, including Point Gordon, Kau Point, Point Halswell and Fort Buckley. The City Corporation and Botanic Garden staff felt that the battery was ugly and distracted from the area both physically and visually. The battery was fenced with barbed wire and vegetation around the battery was cleared to ensure visibility. The seven inch RML gun installed in the Botanic Garden Battery was already obsolete in 1896. By 1904 the Battery was no longer required as Russia had become an ally. Once the battery was no longer in use, the Government stopped maintaining it, and gorse became a problem. The Battery was dismantled in 1904, but remained untended until 1906. In 1906, when former Prime Minister Richard Seddon died, the site chosen for his memorial was the site of the Colonial Observatory. The Hector Observatory, which replaced the Colonial Observatory, was later built on the remains of the Garden's Battery. Part of the battery remains today, as does the gunner's cottage. ${ }^{95}$ Please see section on the Garden's Battery and the Kelburn Scout Hall in the Heritage Inventory.

\section{The Observatory Site}

The Botanic Garden Vesting Act of 1891 contained a clause stating that six acres was to be put aside for the provision of an observatory. In the 1870s the observatory stood on the site of the Seddon Memorial in what is now the Bolton Street Memorial Park. However, as Wellington city grew, the site near town became inappropriate, and the site at the Botanic Garden, high above Wellington city, seemed more practical. However, the site was not used for an observatory until 1907. It was first used for military purposes as discussed in the previous section. In 1906, Prime Minister Richard Seddon died, and a site was chosen for his memorial. Unfortunately, the Colonial Observatory currently occupied the site and had to be hurriedly moved. The new Hector Observatory was built in 1907 on part of the remains of the Garden's Battery. The octagonal shaped observatory was later to be known as the Dominion Observatory. ${ }^{96}$

In 1912 another observatory was built near the Dominion Observatory. The King Edward VII Memorial Observatory, later known as the Thomas King Observatory, was built by the Wellington Philosophical Society as a public observatory. ${ }^{97}$ Please see entry on the Thomas King Observatory in Heritage Inventory.

New Zealand's National Observatory is also part of the Observatory Precinct. The Carter Observatory lies on its own Carter Observatory Reserve and was designed by William Gray Young. ${ }^{98}$

\footnotetext{
${ }_{95}$ Shepherd and Cook, pp. 332-333; Campbell Pope Architect, Lawson Scout Hall Report, no date, p. 3; Wellington City Council, Combined Management Plan, p. 86.

${ }^{96}$ Shepherd and Cook, pp. 337-340.

${ }^{97} \mathrm{~J}$. B. Seymour, A History of the Thomas King Observatory of Wellington unpublished article?, no date, p. 1.

${ }^{98}$ Shepherd and Cook, p. 343.
} 
Despite the fact that the land has been used for observatories since 1907 and provision was made for an observatory reserve in the 1891 Vesting Act, the land was not legally declared an Observatory Reserve until 1962. ${ }^{99}$

\section{The Royal Botanic Garden at Kew}

The Royal Botanic Garden at Kew had a strong influence over the Wellington Botanic Garden. Kew was responsible for the uniform approach to colonial botanic gardens as it produced guidelines for the establishment of botanic gardens. Dr. James Hector had a copy of these guidelines, and by 1883 he had already completed most of them. Like the Wellington Botanic Garden, Kew was also used to test the economic potential of indigenous and exotic plants. Hector had a close relationship with the Hookers, the family who were in charge of Kew for over forty years. J.D. Hooker spent time in New Zealand examining and collecting plant material in 1841 and he also produced a Natural History of the Islands of New Zealand in 1865. Under J oseph Hooker, Kew became the centre of scientific research, botanical classification and distribution of plants for the entire world. ${ }^{100}$

\section{$\underline{\text { The Botanic Garden, fashion and garden styles }}$}

The plantings in the Botanic Garden reflect taste and fashion in gardening from different periods in its 134-year history. Gardening books and catalogues were popular all over the world in the nineteenth century and spread new ideas about plants and designs. In the nineteenth and early twentieth century, 'exoticism and a love of geometric form were characteristics expressed in the Botanic Garden Wellington'. Many native plants were prized for their colours and strongly defined forms. New Zealand native plants were also subtropical, fitting British desires for the exotic. Cabbage trees were first planted in Hector's Teaching Garden and became a prominent feature of the Botanic Garden for the next forty years. It was not only native plants which fulfilled this idea of the tropical. Under MacKenzie Abyssinian bananas were planted on the Main Drive. ${ }^{101}$

Most of the plantings in the Main Garden date from the 1920s to 1980s and so do not represent the nostalgia of the early settlers, Board or City Corporation. The rest of the Garden reflects ideas about science. The native trees were not removed and replaced with Old World trees. Instead the native plants were admired for their uniqueness and their place in New Zealand's ecosystem. Many plants and trees were planted for plant trials and also represent science and a desire to improve the economic success of the Colony. Cook describes the Botanic Garden as a 'huge cabinet of historical curiosities', with the exotic cork oaks from Spain, the Himalayan pines and New Zealand cabbage trees existing in the same space. The Botanic Garden was 'international, eclectic and exotic'. 102

In comparison to the formal Italian nature of the Lady Norwood Rose Garden, Romanticism has influenced much of the rest of the Botanic Garden. Romanticism treasured the wildness of nature and natural features. Rustic features became common in the Botanic Garden. The Mess Room and Stables, and Summerhouse are

\footnotetext{
99 Wellington City Council, p. 13.

100 Shepherd and Cook, pp. 67, 195-199; J . Nigel Hepper, Royal Botanic Gardens Kew: Gardens for Science and Pleasure (London: Her Majesty's Stationery Office, 1982), pp. 1316 ,

${ }^{101}$ Shepherd and Cook, pp. 312-314.

102 Shepherd and Cook, p. 311.
} 
both part of this tradition, as are the map houses near the entrances of the Botanic Gardens. The Board also installed rustic seats and fences as well as Hector's folly. Garden ornaments such as the urns and little boys holding water ewers also relate to the English Romantic garden. ${ }^{103}$

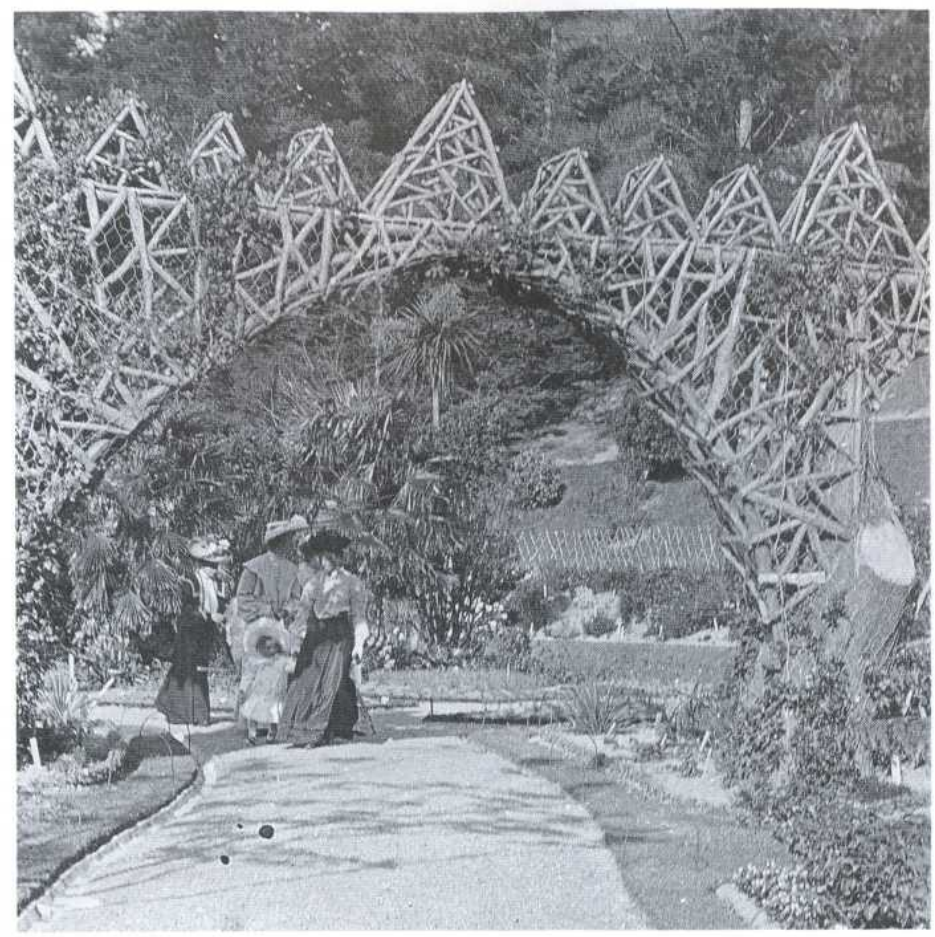

The rustic arch at the Enclosed Garden (formerly Hector's Teaching Garden), c. 1900 [Source: Shepherd and Cook, p. 321].

According to J uliet Ramsey, gardens are the 'matrix which gives form and unity to urban rural landscapes'. She defines botanic gardens as having a focus on botanic collections, plant acclimatisation, floral displays and as places for public events. Many botanic gardens were in the 'paradise' style, with conservatories, tropical houses, stylised features such as curator's cottages and bandstands, elaborate gates, ornaments and memorials. ${ }^{104}$

Ramsey defines the style of a garden as 'the way in which the characteristics of a place are contrived to represent what is considered beautiful, or a particular ideal'. In New Zealand, as in Australia, many gardens were based upon British designs, but had to also contend with different climates and plants. Ramsey outlines many garden styles such as squared gardens, geometric styles, Arcadian gardens, picturesque gardens, the Gardenesque style, and High Victorian gardens. The High Victorian style can be seen in the Lady Norwood Rose Garden, relating to the formal Italianate beds of roses. The Wellington Botanic Garden also demonstrates many elements of the Federation garden. The Federation period is roughly from the 1890s to the 1920s, and includes elements such as gothic

${ }^{103}$ Shepherd and Cook, pp. 318-321.

${ }^{104}$ J uliet Ramsey, Australian heritage Commission Technical Publications, Series Number 2, Parks, Gardens and Special Trees: a Classification and Assessment method for the Register of the National Estate (Canberra: Australian Government Publishing Service, 1991), pp. 1, 6. 
architecture, serpentine paths, mixed plantings and retaining natural contours and features. These elements were seen in the Wellington Botanic Garden of the past, and can still be found there today. Rustic fences and seats, latticework and summerhouses were also features of the Federation garden, and these were also common at the Wellington Botanic Garden. Elements of the Gardenesque style can also be seen, including the emphasis on the scientific, use of native and nontraditional (British) plants and trees, emphasis on the form of plants and shrubs and the ribbon borders and patterned bedding seen under Glen and MacKenzie. ${ }^{105}$

${ }^{105}$ Ramsey, pp. 12-20, 24. 


\section{Notes on the Inventory}

\section{Heritage Inventory}

Each heritage feature, area or building has been given a number which corresponds to its location on the map on the previous page.

The Heritage Inventory is divided into five parts: buildings in the Botanic Garden, features of the Botanic Garden, spaces in the Botanic Gardens, buildings that are closely associated with the Botanic Garden and spaces that are closely associated with the Botanic Garden. That means that the Heritage Inventory also includes areas such as Bolton Street Memorial Park and the Cable Car, which are not officially part of the Botanic Garden but are contiguous and closely associated with the Wellington Botanic Garden.

Under the Historic Places Act 1993, the New Zealand Historic Places Trust/ Pouhere Taonga is required to establish and maintain a register of historic places, historic areas, wahi tapu and wahi tapu areas. The Historic Places Act 1993 section 23, part 1 states that 'the Trust may enter any historic place or historic area in the Register if the place or area possesses aesthetic, archaeological, architectural, cultural, historical, scientific, social, spiritual, technological, or traditional significance or value'. Further guidelines in the second section of the Act states the criteria that historic places and historic areas must meet:

(a) The extent to which the place reflects important or representative aspects of New Zealand history:

(b) The association of the place with events, persons, or ideas of importance in New Zealand history:

(c) The potential of the place to provide knowledge of New Zealand history:

(d) The importance of the place to the tangata whenua:

(e) The community association with, or public esteem for, the place:

(f) The potential of the place for public education:

(g) The technical accomplishment or value, or design of the place:

(h) The symbolic or commemorative value of the place:

(i) The importance of identifying historic places known to date from early periods of New Zealand settlement:

(j) The importance of identifying rare types of historic places:

(k) The extent to which the place forms part of a wider historical and cultural complex or historical and cultural landscape:

(I) Such additional criteria for registration of wahi tapu, wahi tapu areas, historic places, and historic areas of Maori interest as may be prescribed in regulations made under this Act:

(m) Such additional criteria not inconsistent with those in paragraphs (a) to (k) of this subsection for the purpose of assigning Category I or Category II status to any historic place, and for the purpose of registration of any historic area, as may be prescribed in regulations made under this Act. ${ }^{106}$

The Florence Charter was drawn up in December of 1982, and aims to preserve historic gardens around the world. The Florence Charter incorporates both large parks and small gardens. The Charter defines a historic garden as 'an architectural and horticultural composition of interest to the public from the historical or artistic point of view'. The Charter recognises historic gardens as being special because they are a living collection: the 'historic garden is an architectural composition whose constituents are primarily vegetal and therefore living, which means that

\footnotetext{
106 Historic Places Act 1993, s23(2).
} 
they are perishable and renewable. Thus its appearance reflects the perpetual balance between the cycle of the seasons, the growth and decay of nature and the desire of the artist and craftsman to keep it permanently unchanged'. The Florence Charter states that a purely reconstructed garden cannot be considered a historic garden. The Charter suggests that the architectural composition of a historic garden includes the topography and plan, its vegetation, including the species and colour schemes, its structural and decorative features as well as its running and still water. The Charter goes on to say that the historic garden cannot be isolated from its environment, whether urban or rural. That means that the unique place of the Wellington Botanic Garden, just a few minutes from New Zealand's capital city, can be recognised. ${ }^{107}$

The Florence Charter recommends that in order to preserve a historic garden, the identification and listing of the garden is essential. Then various kinds of action, such as maintenance, conservation, restoration or reconstruction can be initiated. The Charter goes on to say that any maintenance, conservation, restoration or reconstruction in a historic garden must be dealt with simultaneously, and any one area of the garden should not be given more attention than others. The Charter takes into the account the need to replant or clear trees as part of a long-term programme for the garden. New plantings must 'be selected with regard for established and recognised practice' in the historic garden. Any architectural, sculptural or decorative features which form an 'integral' art of the garden should only be removed for their restoration or protection, and any restoration or replacement should be recorded as stated by the Venice Charter. Article 15 of the Florence Charter states that "no restoration work and, above all, no reconstruction work on a historic garden shall be undertaken without thorough prior research to ensure that such work is scientifically executed and which will involve everything from excavation to the assembling of records relating to the garden in question and similar gardens'. The Charter also suggests that all restoration work must respect the successive stages of evolution of the garden. ${ }^{108}$

As at the Wellington Botanic Garden, the Florence Charter states that 'active and lively games' should not be undertaken in a historic garden, and instead that a sports ground should be laid out nearby. This occurs at the Wellington Botanic Garden, where Anderson Park is used as a sports ground. The Florence Charter states that 'by reason of its nature and purpose, a historic garden is a peaceful place conducive to human contacts, silence and awareness of nature. Any use of the garden for festivities, such as the Summer City concerts and activities, must be clearly defined so as not to damage the garden. The Charter states that 'all arrangements for visits to historic gardens must be subjected to regulations that ensure the spirit of the place is preserved'. ${ }^{109}$ In article 23 the Florence Charter states that authorities must make appropriate legal and administrative measures to identify, list and protect a historic garden. In the case of the Wellington Botanic Garden, the Wellington City Council has recognised the Garden as a Heritage Place under the District Plan. The Charter also mentions the propagation and care of plants in a historic garden. The Charter continues, recommending that historic gardens must also be involved in sharing knowledge and education, research and publications, and encourage public access and enjoyment of the garden. ${ }^{110}$

\footnotetext{
107 http:/ / www. international. icomos. org/ charters/ gardens_e. htm

108 http:/ / www. international. icomos. org/ charters/ gardens_e. htm

$109 \mathrm{http}$ :/ / www. international. icomos. org/ charters/ gardens e. htm

$110 \mathrm{http}: / /$ www. international. icomos. org/ charters/ gardens_e. htm
} 
As well as the Florence Charter, the ICOMOS New Zealand Charter for the Conservation of Places of Cultural Heritage Value is applicable to the Botanic Garden. The Charter states that 'areas, landscapes and features, buildings, structures and places, archaeological and traditional sites, and sacred places and monuments are treasures of distinctive value'. The ICOMOS New Zealand Charter sets out principles to guide the conservation of places of cultural heritage value in New Zealand. The ICOMOS New Zealand Charter for the Conservation of Places of Cultural Heritage Value defines conservation as 'care for places of cultural heritage value, their structures, materials and cultural meaning'. The places should have 'lasting values and can be appreciated in their own right', they should 'teach us about the past', 'provide the context for community identity', and 'provide visible evidence of the continuity between the past, present and future'. The Charter suggests eight forms of conservation of historic places and areas: non-intervention, maintenance, stabilisation, repair, restoration, reconstruction, adaptation and interpretation. Re-creation and replication (such as the replica Memorial Chapel at the Bolton Street Memorial Park) are beyond the scope of the Charter. ${ }^{111}$

The Wellington Botanic Garden also fits several of Juliet Ramsey's criteria for protecting or registering a garden. These include the long period of enjoyment of the garden by the public; its value as a landmark; its sentimental and recreational value; its importance as a community and education site; its contribution to the wider understanding of human occupation in the city or country; and its association with events which had a significant role in human occupation and evolution of the nation, state, region or community. ${ }^{112}$ The Wellington Botanic Garden is also closely associated with science, organisations such as the New Zealand Institute, the Wellington Philosophical Society and institutions such as the Colonial Museum and Wellington City Council.

111 http:// www. icomos. org/ docs/ nz_92charter. html

112 Ramsey, pp. 45-48. 


\section{Map Key}

1. Overseer's Cottage

2. Lawson Scout Hall

3. Director's Residence

4. Gazebo/summerhouse

5. Mess Room and Stables

6. Ladies Rest Room

7. Norwood Begonia House/ Lily House/ Teahouse

8. Urns

9. Children with water ewers

10. Annie's Seat

11. William Bramley Drive

12. Ludlam Drive

13. Buchanan Way

14. William Wakefield Way

15. Myrtle Way

16. Grass Way

17. Mamuku Way

18. Manuka Way/ Path

19. Camellia Path

20. Kew Way

21. Rocky Way/ Path

22. Junction Path/ Way

23. Glenbervie Entrance and Path

24. East Path

25. West Way

26. Pine Hill Path

27. Serpentine Way

28. Norwood Path

29. Gorse Path

30. Druid Hill

31. J oy Fountain

32. Lady Norwood Rose Garden Fountain

33. Main Entrance Gates

34. Lady Norwood Rose Garden

35. Sound Shell Lawn

36. Magpie Lawn

37. Duck Pond

38. Observatory Precinct

39. Dominion Observatory

40. Thomas King Observatory

41. Carter Observatory

42. Meteorological Office

43. Cable Car Winding House

44. Sexton's Cottage

45. Bolton Street Memorial Park

46. Anderson Park 


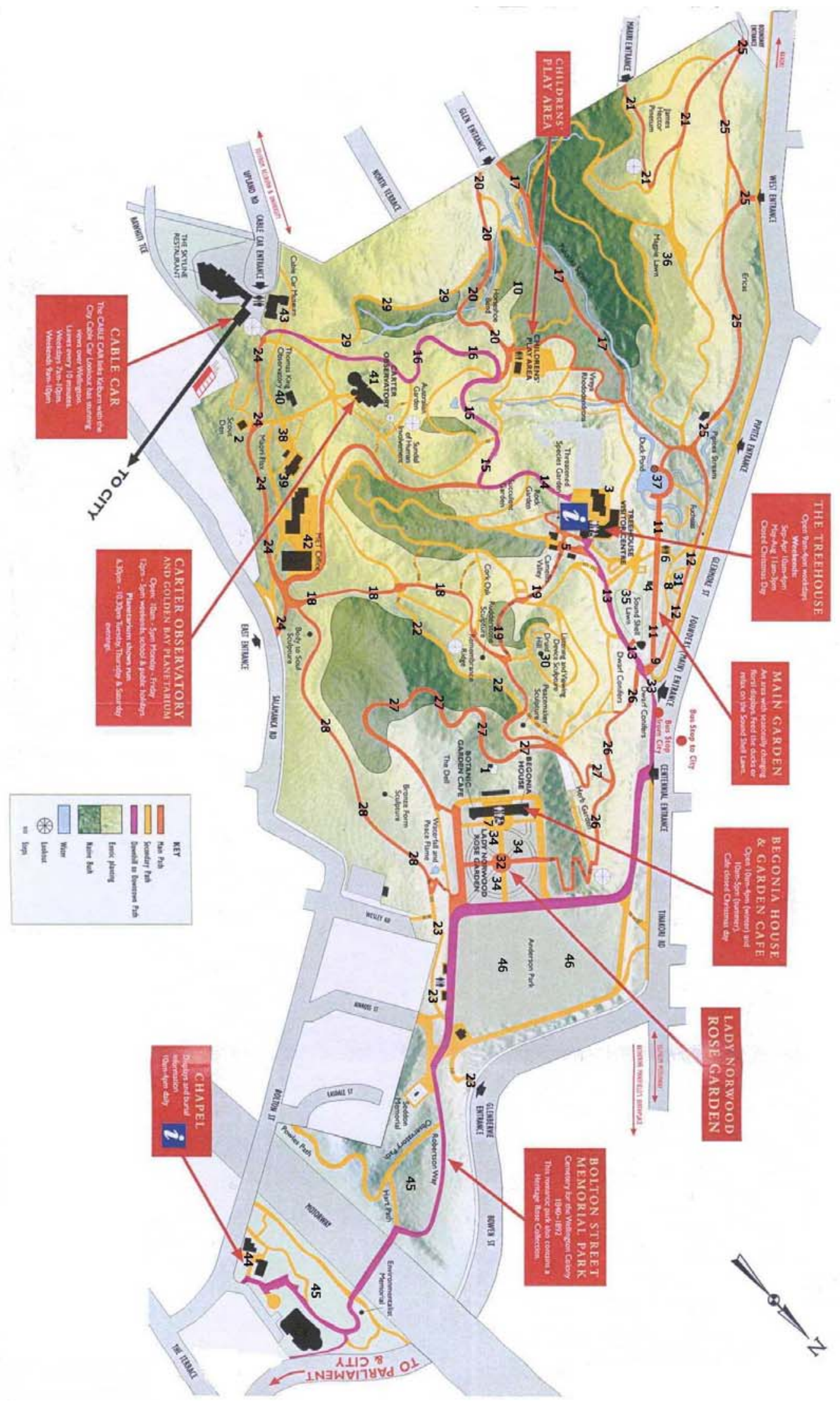

[Source: Wellington City Council]. 


\section{Buildings in the Botanic Garden:}

\section{Overseer's Cottage}

Also known as the Constable's Cottage, the Constabulary and the Ranger's Cottage.

NZHPT Classification II

District Plan: Map 17, Reference 29.

Map reference (1)

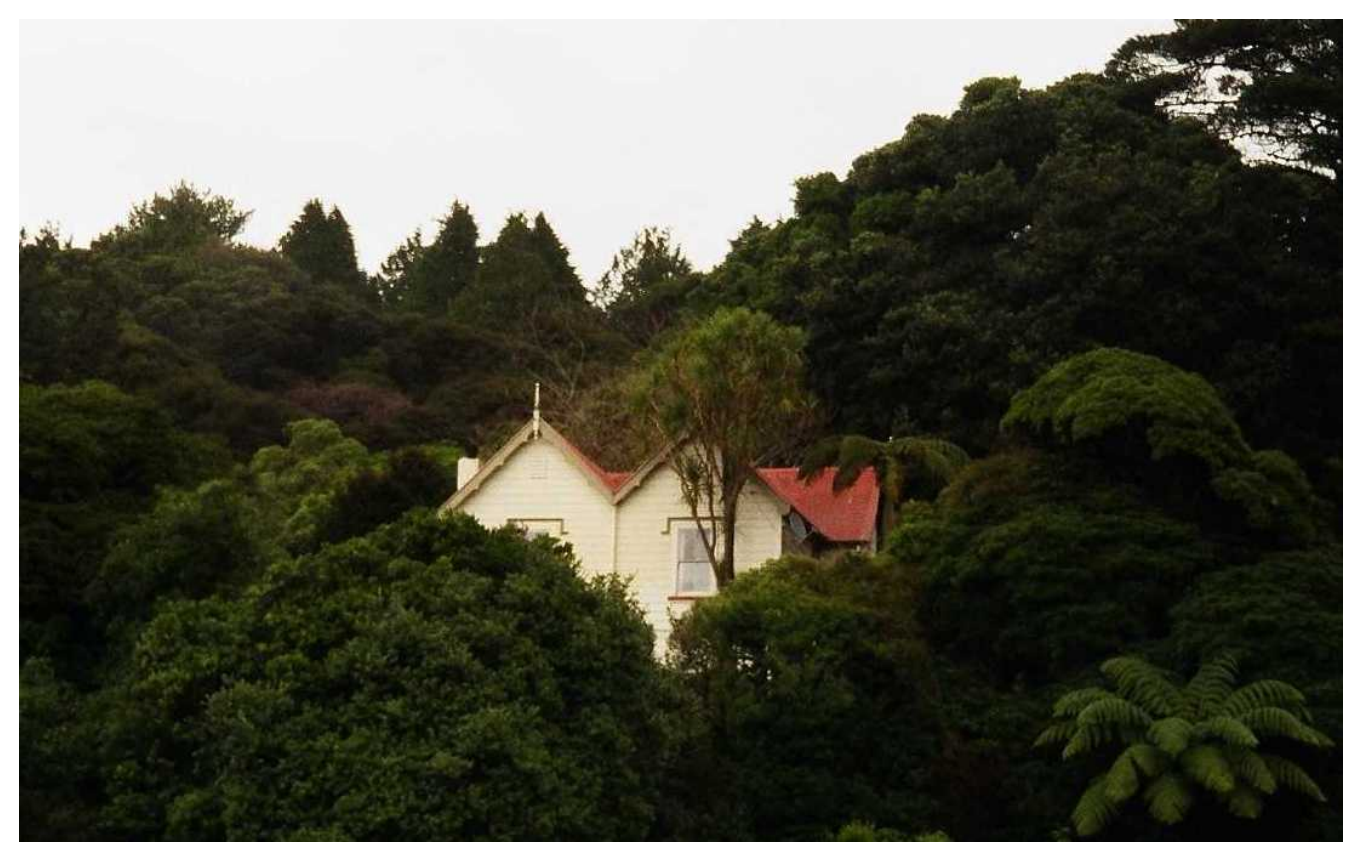

View of Overseer's Cottage

\section{Description:}

The Overseer's Cottage was built in 1876 and designed by Douglas and Heder architects. ${ }^{113}$ Horticultural staff at the Botanic Garden live here, and have a role in security in the Gardens. ${ }^{114}$ The Cottage sits on the Serpentine Path, a bush walk, overlooking the Gardens and especially the Lady Norwood Rose Garden and the Dell.

\section{Architectural Style:}

The Overseer's Cottage is described as Victorian Tudor in the Wellington City Council Heritage Inventory. The cottage is of timber construction, with rusticated weatherboards, timber joinery and detailing (including finials and bargeboards). The roof is of corrugated iron. The building is symmetrical and simple. There are two matching pitched roofs, 'each with simple gable ends terminating in finials'. The windows are double hung with four-light sashes. The label moulds above the

${ }^{113}$ www. wcc. govt. nz/ wellington/ heritage/ inventory/ pg51. html.

114 Wellington City Council, p. 69. 
windows are not only highly decorative: they also divert rainwater running down the wall face away from the wall opening. ${ }^{115}$

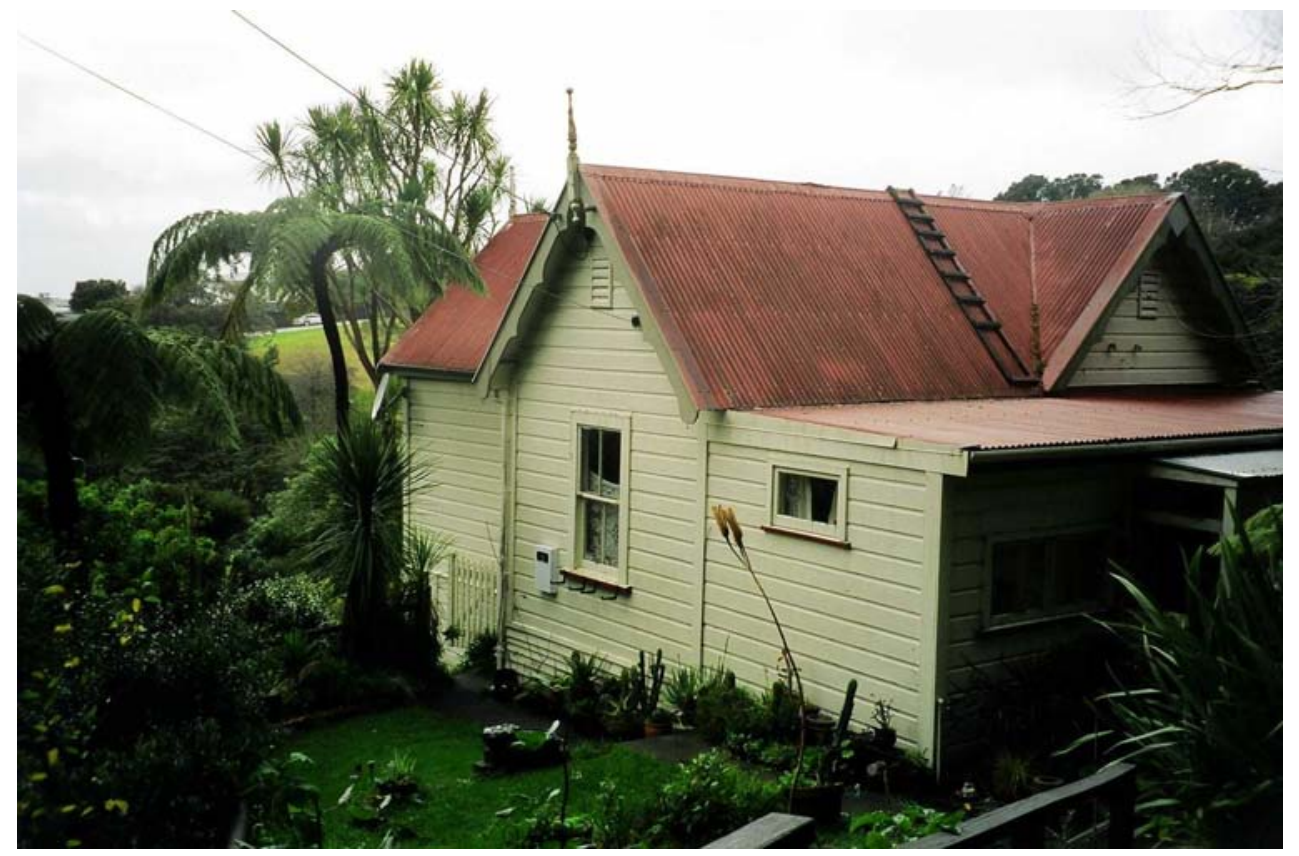

The Overseer's Cottage, rear.

\section{History:}

Because of the scale of the Garden, the responsibility for keeping law and order became too much for the Keeper and head gardener of the time, Mr. William Bramley. A cottage was needed to oversee the Glenbervie section of the Garden. A site with a commanding view over the Botanic Garden was chosen in 1876, and $£ 150$ voted by the Board for the construction of a cottage. A tender of $f 123$ by Douglas and Heder was selected, and 2000 feet of kauri timber was ordered for lining the cottage. ${ }^{116}$ The first constable to occupy the cottage was Constable Campbell, who moved into the cottage in May 1880. However, there were still numerous complaints of vandalism and damage in the Garden and Campbell was replaced by Constable J ames Gleeson in 1882. ${ }^{117}$ Constable Whelan took over in 1890. The Cottage was occupied by constables from 1880-1898, when the Custodian's assistant took over the cottage. Problems with 'loiterers with evil intent' continued, and uniformed and plain clothed policemen continued to patrol the Garden into the 1920s. The Garden staff were also made special constables in 1904. ${ }^{118}$

Since then, horticultural staff and students have lived in the cottage.

\footnotetext{
${ }^{115}$ www. wcc. govt. nz/ wellington/ heritage/ inventory/ pg51. html

${ }^{116}$ Shepherd and Cook, p. 61.

117 Shepherd and Cook, pp. 63-4

${ }^{118}$ Shepherd and Cook, pp. 240, 242.
} 


\section{Modification:}

In 1946, extensive renovations were made to the Overseer's Cottage. These involved the foundations, chimney, floors, spouting, roof, floor joists, hot and cold water supply and treatment for borer. The renovations cost $£ 590 .{ }^{119}$

In August of 1947, the urgent need for a bathroom in the cottage was recognised, and plans were drawn up. The bathroom was added to the scullery in the form of a lean-to. ${ }^{120}$ Previously, the bathroom had been an outhouse supplied by hot water from a copper. ${ }^{121}$

However, according to the Wellington City Council Heritage Inventory, the cottage 'retains functional use values'. ${ }^{122}$

\section{Level of authenticity:}

According to the Wellington City Council's Heritage Inventory, the Overseer's Cottage 'maintains a high level of authenticity in setting and craftsmanship'. ${ }^{123}$

\section{Assessment of significance/heritage values:}

\section{Historical:}

The Overseer's Cottage is the oldest building in the Botanic Garden. It is closely associated with the establishment and development of the Botanic Garden and 'it remains an important element in the garden environment and can be clearly seen amongst the trees and bushes'. ${ }^{124}$

The Overseer's Cottage is related to the history of the Botanic Garden as it provides a link between the current horticultural staff who live in the cottage and the generations of gardeners and Keepers who have also lived there.

The Overseer's Cottage is the only surviving building from the time of the Botanic Garden Board.

\footnotetext{
119 Wellington City Corporation City Engineer's Department, Repairs and Additions to Caretaker's Cottage, Botanical Gardens, 24 October 1946 (located in WCC File 00009: 486: 21/21/ 3 - Residences-Botanical Gardens Director of Parks and Reserves. Custodians).

120 Wellington City Corporation, City Engineer's Dept, Renovations to Caretaker's Cottage, Botanical Gardens, Plan, by K.E. Luke 7 August 1947 (located in WCC File 00009: 486: 21/21/ 3 - Residences-Botanical Gardens Director of Parks and Reserves. Custodians).

121 Memorandum for the Director of Parks and Reserves, from the City Engineer, 23 October 1946 (located in WCC File 00009:486:21/21/ 3 - Residences-Botanical Gardens Director of Parks and Reserves. Custodians).

122 www. wcc. govt. nz/ wellington/ heritage/ inventory/ pg51. html

123 www. wcc. govt. nz/ wellington/ heritage/ inventory/ pg51. html.

${ }^{124}$ www. wcc. govt. nz/ wellington/ heritage/ inventory/ pg51. html
} 


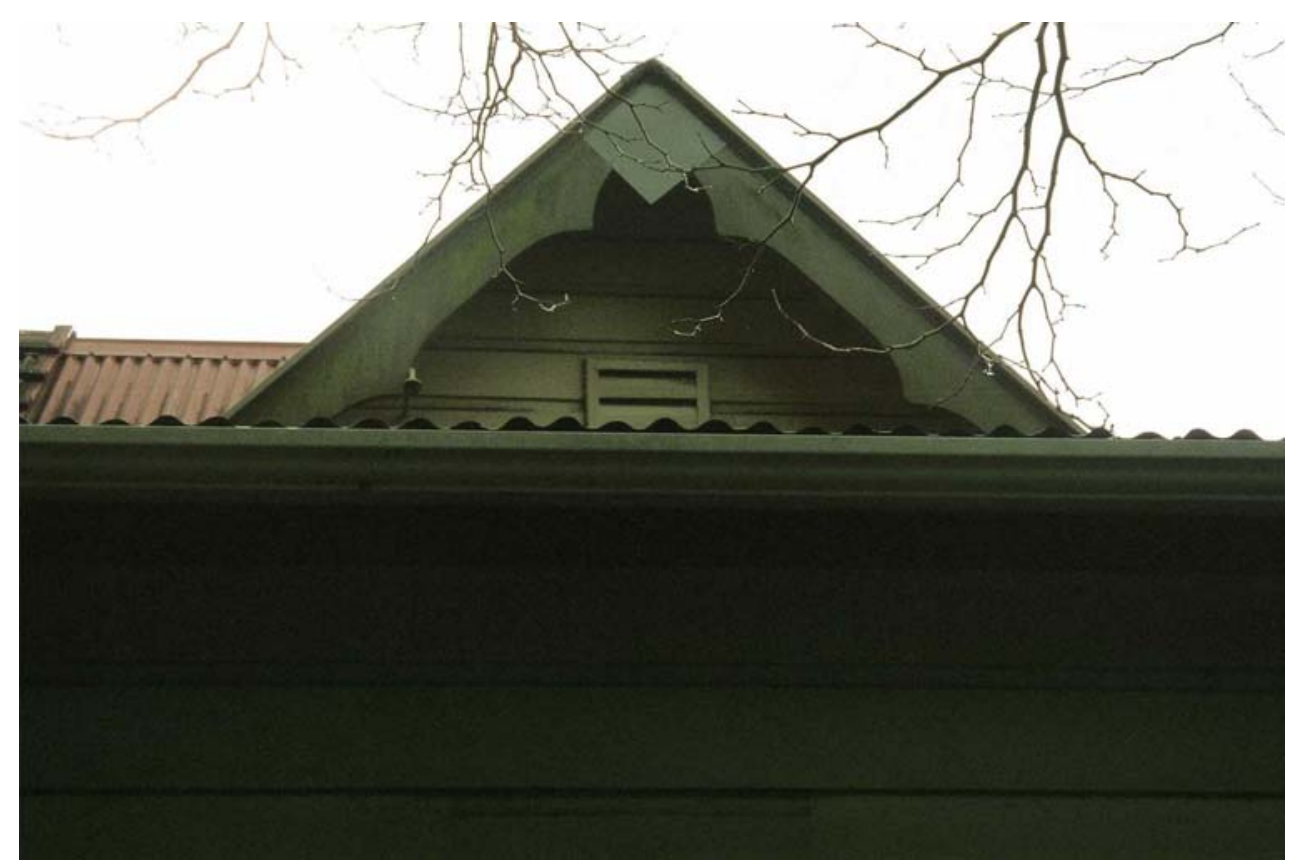

Close up of decorative details.

\section{Architectural}

According to the Wellington City Council's Heritage Inventory, 'the double-roofed cottage type is not a common house form and in its present setting the Overseer's House is a distinctive and pleasant composition'.125 Therefore the cottage is architecturally rare.

The cottage is also representative of its time period, and according to the Wellington City Council Heritage Inventory, the 'cottage is a simple but interesting example of residential architecture, and has elements particular to the period, such as label moulds'. 126

The style of the cottage goes back to the Early English or Victorian Gothic styles. This is a revival of a late medieval style of English cottages which included steeply pitched roofs, mullioned windows and moulding to deflect rain. ${ }^{127}$

\section{Aesthetic}

The Overseer's Cottage has landmark value, as it is snuggled into the hillside near the popular Lady Norwood Rose Garden. It is a popular and familiar feature in the Garden. Walter Cook remarks that it is an important ornamental feature of the Botanic Garden, 'standing white and picturesque among the evergreen native and exotic trees planted around it. This building is another link with the Romantic Garden and the ornamental architecture that went with it'. ${ }^{128}$ The Overseer's Cottage also relates to the aesthetic values of the Federation Garden. ${ }^{129}$

\footnotetext{
125 www. wcc. govt. nz/ wellington/ heritage/ inventory/ pg51. html

${ }^{126}$ www. wcc. govt. nz/ wellington/ heritage/ inventory/ pg51. html

127 Shepherd and Cook, pp. 323-324.

128 Shepherd and Cook, p. 324.

${ }^{129}$ Ramsey, pp. 17-19.
} 


\section{Lawson Scout Hall:}

The Lawson Scout Hall is not recognised by the New Zealand Historic Places Trust or the Wellington City Council District Plan

Pt section 1223, Town of Wellington, Block VI Port Nicholson Survey District

Map reference (2)

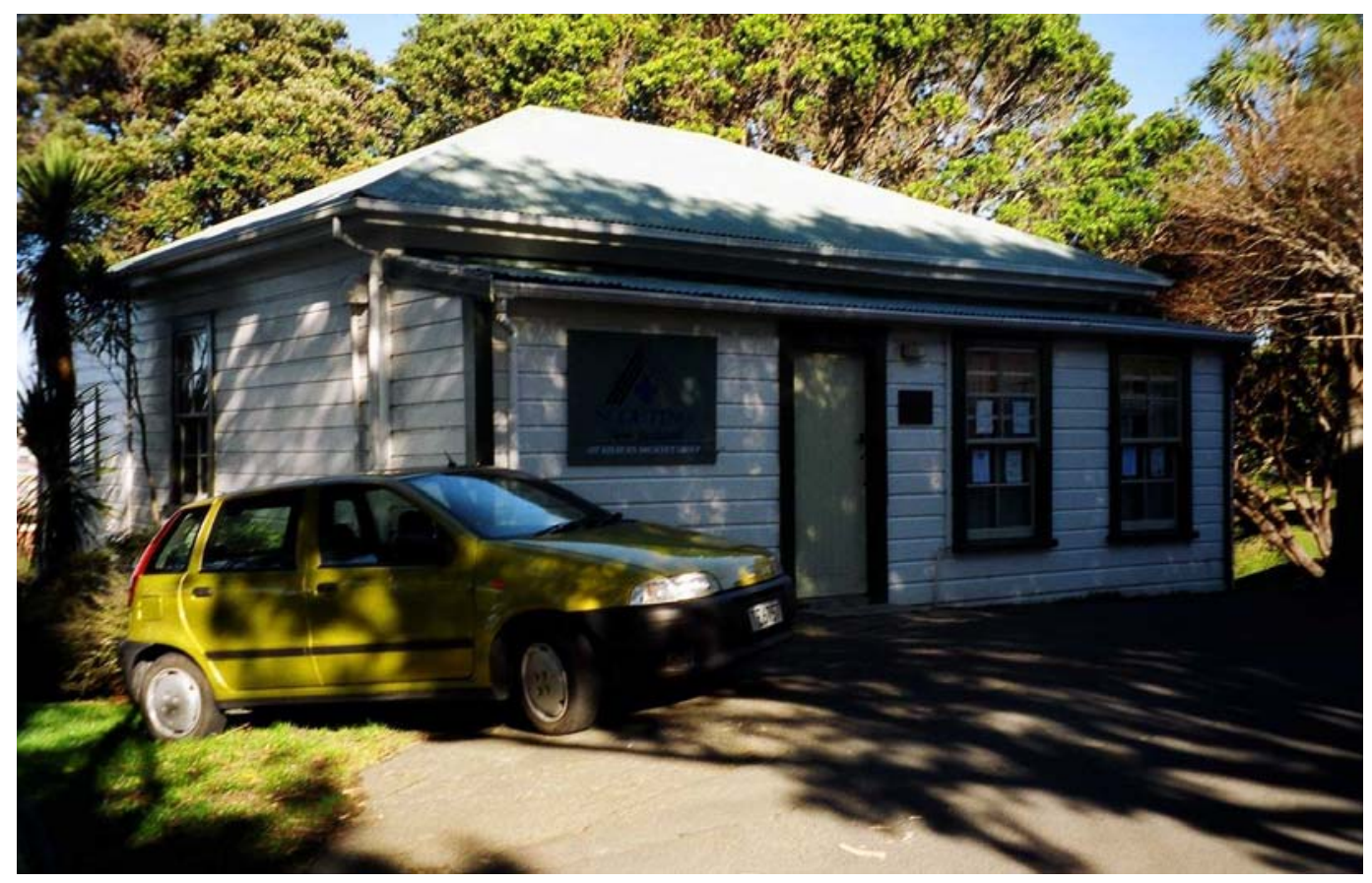

The Lawson Scout Hall, front view.

\section{Description:}

Lawson Scout Hall is a converted dwelling on the East Way of the Botanic Gardens. The hall is owned by the Kelburn Scout Group, and the land is currently leased from the Department of Conservation. The building consists of a single storey, and has an area of $101.7 \mathrm{~m}^{2}$. The building is timber framed, and clad with rusticated weatherboard and has a corrugated iron roof. ${ }^{130}$

\section{Architectural style:}

The building was originally a cottage in the square villa style, but successive additions have changed the character of the building. The building is described as 'utilitarian' in Campbell Pope Architect's report. ${ }^{131}$

130 Campbell Pope Architect, p. 1.

${ }^{131}$ Campbell Pope, p. 8. 


\section{History:}

The villa was built as the resident gunner's house for the Botanic Gardens Battery in about 1896 (see entry for Botanic Gardens Battery). By 1904 the cottage was

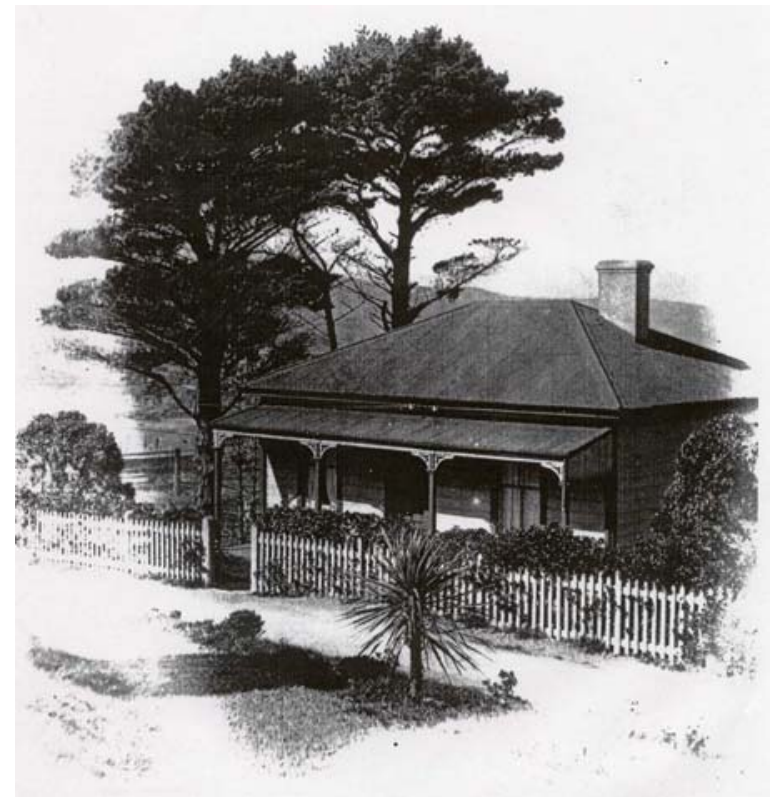

The gunner's cottage which later became the Lawson Scout Hall [Source: Shepherd, unpublished source]. probably used for general army housing, and as late as 1912, it was used as a dwelling for a noncommissioned officer of the Defence Department. ${ }^{132}$ Not long after this, the cottage was used as the Custodian's House for the Cable Car. ${ }^{133}$

The building was given to the Kelburn Scout Group in 1913, and is the oldest scout den in New Zealand. The Kelburn Scout Group is the oldest continuously operating Scout Group in New Zealand. ${ }^{134}$ Scoutmaster Eric Lawson founded the Kelburn Scout troop in 1909. The troop originally met in private homes, but by 1912 had raised funds for a building, and approached the Minister of Internal Affairs to have a site made available. After a meeting with government ministers, permission was given to build or to take over an existing building. The Boy Scout movement of the time was 'quasi-military in intent' and the position of the den on Ministry of Defence land near the Gardens Battery seemed appropriate. In 1911 the Boy Scout Movement was integrated into the 1911 Defence Scheme of New Zealand. The Scouts took over the cottage and removed the internal walls. The den was formally opened on 31 May 1913. During the First World War the Kelburn Scouts acted as Defence Department messengers and during the 1918-19 influenza pandemic, the scouts worked in emergency hospitals. During the Second World War, the Kelburn Scout Group continued their good works, taking over sports coaching and odd jobs as the male population diminished. Many now distinguished New Zealanders were once members of the troop. ${ }^{135}$

Since then, the hall has been in continuous use as a Scout den.

\section{Modification:}

The building has been significantly altered since its construction: the interior walls have been removed; the load bearing walls on the east and west have been removed and replaced with beams; the veranda has been enclosed; the front door and window joinery have been relocated to the new exterior wall. The floor has also been rebuilt after two fires, and a freestanding toilet block was added in

\footnotetext{
132 Campbell Pope, p. 5.

133 Shepherd, unpublished source, p. 89.

134 Campbell Pope, p. 1.

135 Campbell Pope, pp. 6-7.
} 
1990. ${ }^{136}$ In 1959, the building was enlarged by demolishing the west wall, and new exterior wall was built, reusing original weatherboard and joinery. In 1984, the 'scouters room' was replaced with a kitchen and leader's room. There have been three major fires in the den: in 1934, 1969 and 1996. ${ }^{137}$

\section{Assessment of significance/heritage values:}

\section{Historical:}

The Kelburn Scout Hall is the oldest Scout Den in New Zealand, and the Kelburn Scout Group is the oldest continuously operating Scout Group in the country. ${ }^{138}$ The Kelburn Scout Hall is significant because of its 'history, atmosphere and setting' and is important to the Scouting history of New Zealand. ${ }^{139}$

As remains belonging to the time of the 'Russian Scare', the Scout Hall and Botanic Gardens Battery are easily accessible and are the only nineteenth century coastal defence sites where 'timber ancillary buildings remain to give a picture of the relationship between the fortification and the men who served the guns'. ${ }^{140}$ The Scout Hall is also connected to the Cable Car, as it was used as housing for the custodian of the Cable Car.

The building is part of the Observatory Precinct. ${ }^{141}$

\section{Social:}

The Kelburn Scout Hall is very closely associated with the past and present members of the Lawson Scout Group. As the oldest Scout den in the country, and as the home of the oldest continuous Scout Group in the country, the Hall has social significance.

\footnotetext{
${ }^{136}$ Campbell Pope, p. 2

137 Campbell Pope, pp. 7-8.

138 Campbell Pope, p.1.

139 Campbell Pope, p. 9.

${ }^{140}$ Campbell Pope, p. 8.

${ }^{141}$ Campbell Pope, p. 8.
} 


\section{Director's Residence:}

The Director's Residence is not recognised by the New Zealand Historic Places Trust or the Wellington City Council District Plan

Map reference (3)

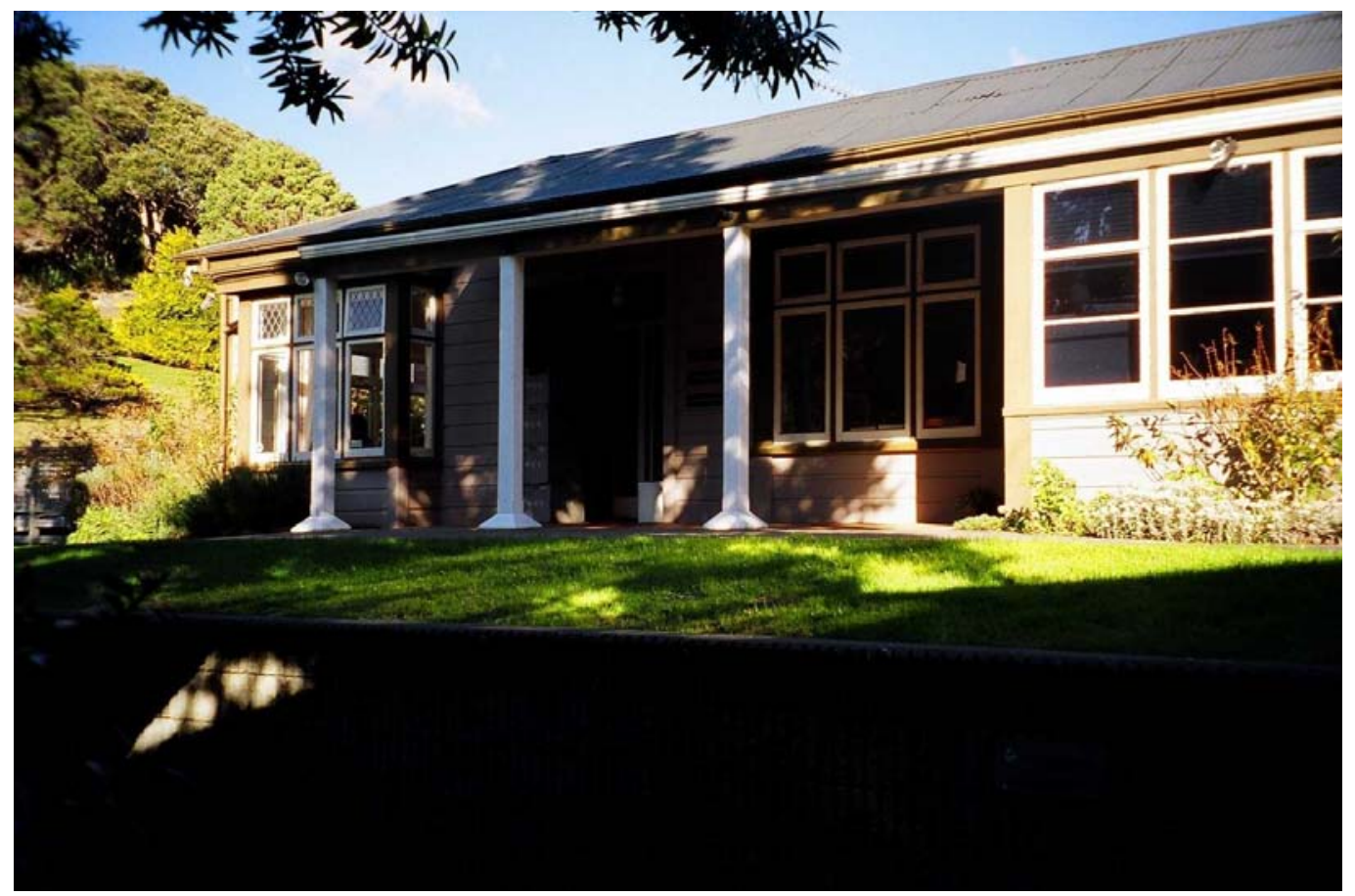

The Director's House.

\section{Description:}

The Director's Residence was built on the site of what must be the first building on what was to become Botanic Gardens land. The original Randall or Keeper's Cottage was demolished about 1892, and the villa that stands today was constructed about 1902. Every Keeper/Curator/Director of the Wellington Botanic Garden from 1904 to 1989 has lived here.

\section{Architectural style:}

The Director's Residence is an Edwardian villa, and was constructed in 1902. The villa elements can be seen in the roof and window style, the wooden construction and the porch.

\section{History:}

The Randall Cottage stood on the site that is now the Director's Residence. The Randall Cottage was built in 1852 by J ohn Dutton on what was then the Wesleyan Reserve. ${ }^{142}$ Dutton was recorded as being resident of the cottage or lean-to in the 1856 electoral roll and 1859 jury list. ${ }^{143}$ The cottage was built of the rimu and

142 Shepherd, unpublished source, p. 75.

${ }^{143}$ Shepherd and Cook, p. 48. 
kahikatea available on the Wesleyan Reserve. In 1860 the cottage was bought by William Randall. The land was bought back by the Crown in 1865, and the cottage was sold to Mr. David Hall for $£ 25$ in 1868. ${ }^{144}$ Hall offered himself as keeper of the Garden, and worked as such until William Bramley was hired. The Board purchased the cottage for $\mathrm{f} 45$ from Hall in 1870 , and Bramley and his family moved in. The cottage became known as the Keeper's Cottage. In 1880, Bramley reported that the roof was leaking badly and that he needed another room to be added because of his growing family. Further repairs were undertaken in 1889, when the new Head Gardener, George Gibb, came to live there. ${ }^{145}$ According to Shepherd and Cook, the cottage was demolished in $1892 .{ }^{146} \mathrm{~A}$ fourroomed bungalow with a veranda was built 1892 to replace the Keeper's Cottage until the Director's Residence was built. ${ }^{147}$

George Gibb lived in the Director's Residence until 1901, when he lost both his legs in an accident, and retired as Keeper.

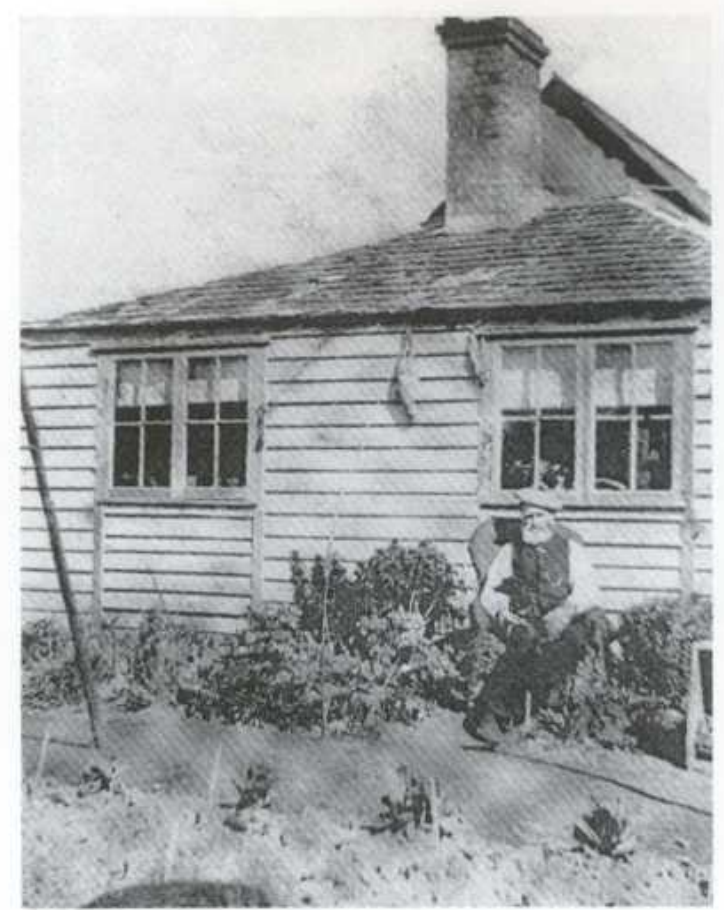

George Gibb sitting outside the Randall Cottage, shortly before its demolition in 1892 [Source: Shepherd, Wellington's Heritage, p. 219].

George Glen took over as Keeper. ${ }^{148}$ In 1902, the new custodian's residence was completed. This building stands today, although it has been extended and modified over time. ${ }^{149}$

\section{Modification:}

The Director's Residence was modified in 1929 when a new chimney was added, the kitchen extended and a bay window added. The new kitchen floor and outside wall were to be of matai, with totara piles, rimu sleepers and rimu picture rails. ${ }^{150}$ The work was done by $\mathrm{H}$. Stanford at a cost of $f 221.6 .8 .{ }^{151}$

\footnotetext{
144 Shepherd, unpublished source, p. 75.

145 Shepherd and Cook, pp. 47-48, 65-66.

146 Shepherd, unpublished source, p. 75.

147 Winsome Shepherd, Wellington's Heritage Plant, Gardens and Landscape (Wellington: Te Papa Press, 2000), p. 219: Shepherd and Cook, p. 234.

148 Shepherd, unpublished source, p. 75.

149 Shepherd, Wellington's Heritage, p. 219.

150 Wellington City Corporation Specifications and General Conditions Contract No. 1397

Contract for Alterations and Additions to Residence; Botanical Gardens: Wellington, 12

August 1929 (located in WCC File 00009: 486:21/21/ 3 - Residences-Botanical Gardens

Director of Parks and Reserves. Custodians).

151 Memo to Town Clerk from City Engineer, 22 August 1929 (located in WCC File

00009: 486: 21/ 21/ 3 - Residences-Botanical Gardens Director of Parks and Reserves.

Custodians).
} 
The bathroom and hall of the Director's Residence was renovated in 1941 at a cost of about $f 112 .{ }^{152}$

When Edward Hutt became Director of the Garden in 1946, more work was done on the Director's Residence. These included both structural and interior renovations such as new linings, wallpaper etc. It was hoped that this would bring the 1902 building 'up to a reasonably modern standard'. ${ }^{153}$

The Residence now serves as the Botanic Gardens Reference Library, and houses offices and a small flat. The last Director of the Botanic Garden lived in the Director's Residence until 1989, and in 1991 the conversion into the flat, office and library was completed. ${ }^{154}$

\section{Assessment of significance/heritage values:}

\section{Historical}

The Director's Residence was built on the site of the first cottage in the Botanic Garden and so links the building to the very early days of the Botanic Garden reserve. The building has been in continuous use since then, and has been home to most of the Directors of the Botanic Garden.

\section{Architectural}

The Director's Residence is in the 'roof over the verandah' villa style. ${ }^{155}$

152 Memorandum from L. A. to City Engineer, 27 J une 1941; Quotation from Winstone Limited, 2 September 1941; Letter from the City Engineer to the Town Clerk, 16 September 1941 (all located in WCC File 00009:486:21/21/ 3 - Residences-Botanical Gardens Director of Parks and Reserves. Custodians).

153 Letter from City Engineer to F. D. Stewart, District Building Controller, 26 March 1946

(located in WCC File 00009:486:21/ 21/ 3 - Residences-Botanical Gardens Director of Parks and Reserves. Custodians).

154 Mike Oates, personal communication, 15 August 2003.

155 J eremy Salmond, Old New Zealand Houses 1800-1940, (Auckland: Reed Methuen

Publishers, 1986), p. 171. 


\section{Gazebo/Summerhouse}

District Plan Reference: Map 11, reference 28.

The Gazebo/summerhouse is not recognised by the New Zealand Historic Places Trust

Map reference (4)

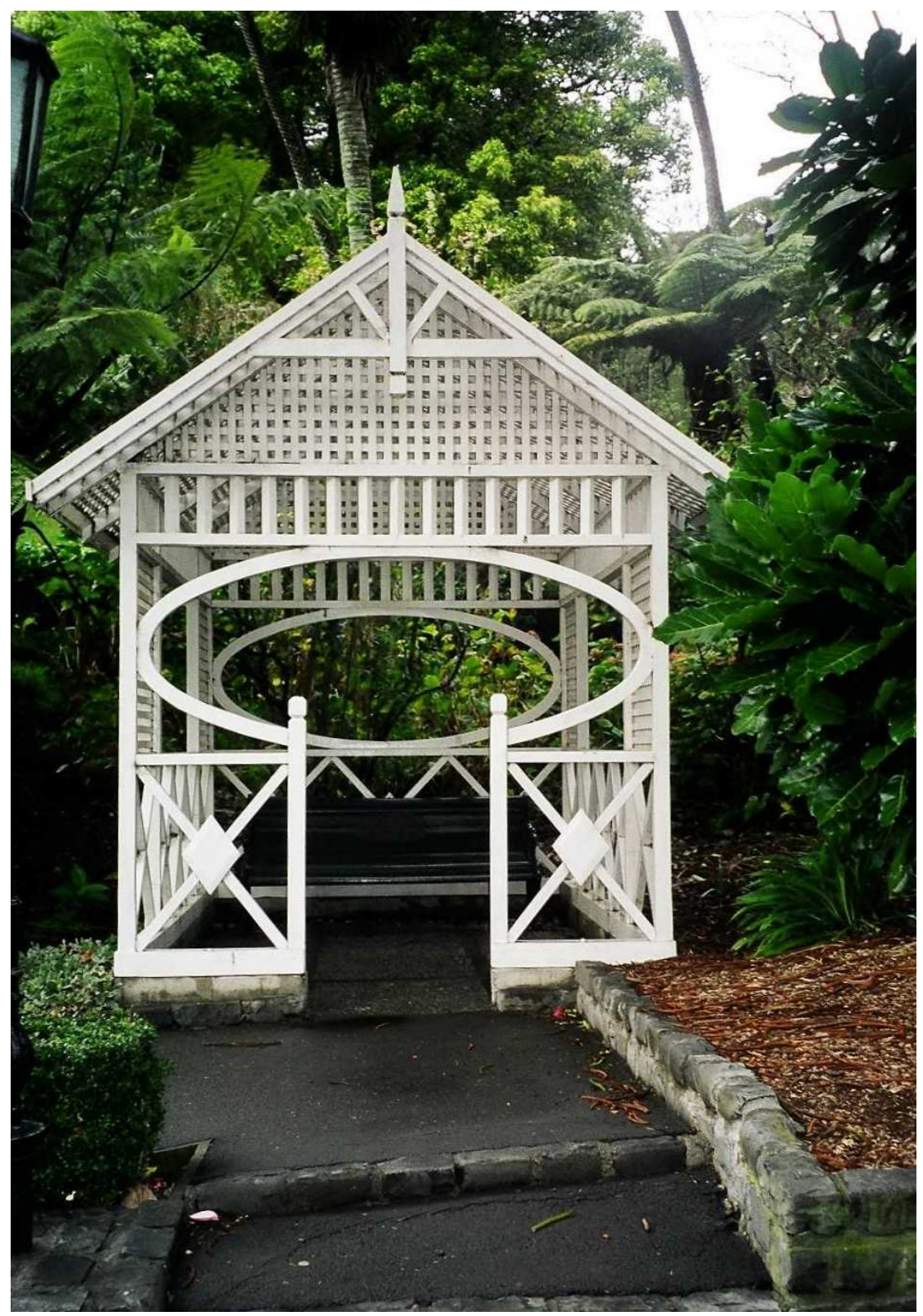

The Gazebo/ Summerhouse.

\section{Description:}

The Gazebo/summerhouse is a white painted latticed redwood timber summerhouse. It is located between Founders Entrance and the Duck Pond. 


\section{Architectural Style:}

The Gazebo/summerhouse is in the Federation or Edwardian Carpenter Gothic style. This style is often used for ecclesiastical buildings, and the decorative and projecting gable which is typical of the style can be seen here. A variation on the Gothic foil motif can also be seen in the Gazebo/summerhouse. The style makes great use of the carpenter's skill and emphasises 'truth to materials'. ${ }^{156}$

\section{History:}

The Gazebo/summerhouse was apparently built for Mr. William Mudge and was part of a float in the Labour Day parade in 1914. The Town Clerk approached the Carpenter's Union on 7 November and offered $f 15$ for the float. The price was settled at f20, and the summerhouse was installed in its present site on 1 December 1914. ${ }^{157}$

The Gazebo/ summerhouse houses a cast iron chair with a plaque which reads:

'In memory of a hero.

William J ohn Morris, aged 10

who was drowned in a gallant attempt to save his younger brother.'

It is dated 30 J uly 1891.158

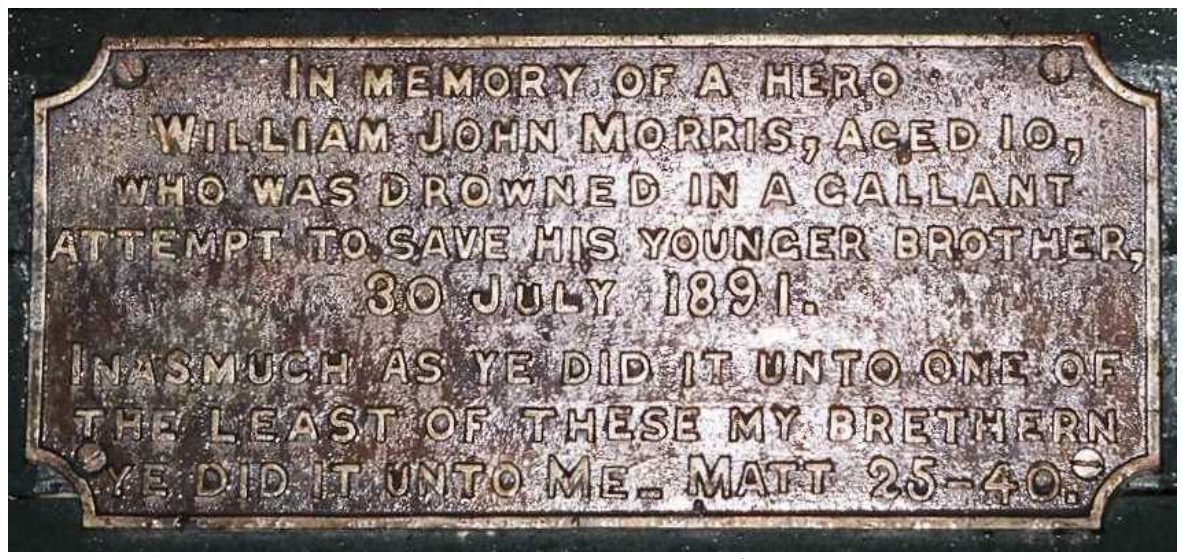

Memorial plaque in the Gazebo/ Summerhouse.

\section{Modification:}

The Gazebo/summerhouse has been overhauled in the last few years, and a great deal of the joinery replaced. The base was adapted and strengthened at some cost. However, the Gazebo/summerhouse maintains the character and design of the original and will now last for many more years to come. ${ }^{159}$

\footnotetext{
${ }^{156}$ www. wcc. govt.nz/ wellington/ heritage/ inventory/ pg50.html; Peter Shaw, New Zealand Architecture: from Polynesian Beginnings to 1990, (Auckland: Hodder and Stoughton, 1991), p. 34.

${ }^{157}$ www. wcc. govt.nz/ wellington/ heritage/ inventory/ pg50. html; David McGill and Grant Tilly, Cityscapes (Wellington: Methuen Publishing New Zealand Ltd, 1977), p. 14.

${ }^{158}$ Shepherd and Cook, p. 322.

159 Mike Oates, personal communication, 12 August 2003.
} 


\section{Level of Authenticity:}

The Gazebo/ summerhouse maintains the character of the original gazebo.

Assessment of significance/heritage values:

Historical:

According to the Wellington City Council Heritage Inventory, the Gazebo/ summerhouse 'is an elegant structure which has long association with the Botanic Garden, and is still well utilised as a shelter and lookout'. ${ }^{160}$

David McGill and Grant Tilly describe the Gazebo/ summerhouse as the 'true heart of the Gardens' ${ }^{161}$

The Gazebo/summerhouse relates to the Victorian heritage of the Main Drive. Summerhouses were a key element of the Federation garden style. ${ }^{162}$

\section{Architectural:}

According to the Wellington City Council Heritage Inventory, the Gazebo/summerhouse is '[a]n interesting record of a turn-of-the-century gazebo/summerhouse, giving an indication of the prominent styles and construction techniques of the period'. ${ }^{163}$

\section{Aesthetic}

The Gazebo/ summerhouse has landmark value because of its long association with the Botanic Garden and especially the Main Garden. It is in keeping with the Victorian character of the Main Garden and relates to the rustic style which was popular throughout the Botanic Garden in the early twentieth century.

\footnotetext{
${ }^{160}$ www. wcc. govt. nz/ wellington/ heritage/ inventory/ pg50. html.

161 McGill and Tilly, p. 14.

162 Ramsey, p. 19.

163 www. wcc. govt. nz/ wellington/ heritage/ inventory/ pg50. html.
} 


\section{Mess Room and Stables}

Also known as the Gardener's Sheds

The Mess Room and Stables are not recognised by the New Zealand Historic Places Trust or Wellington City Council District Plan

Map reference (5)

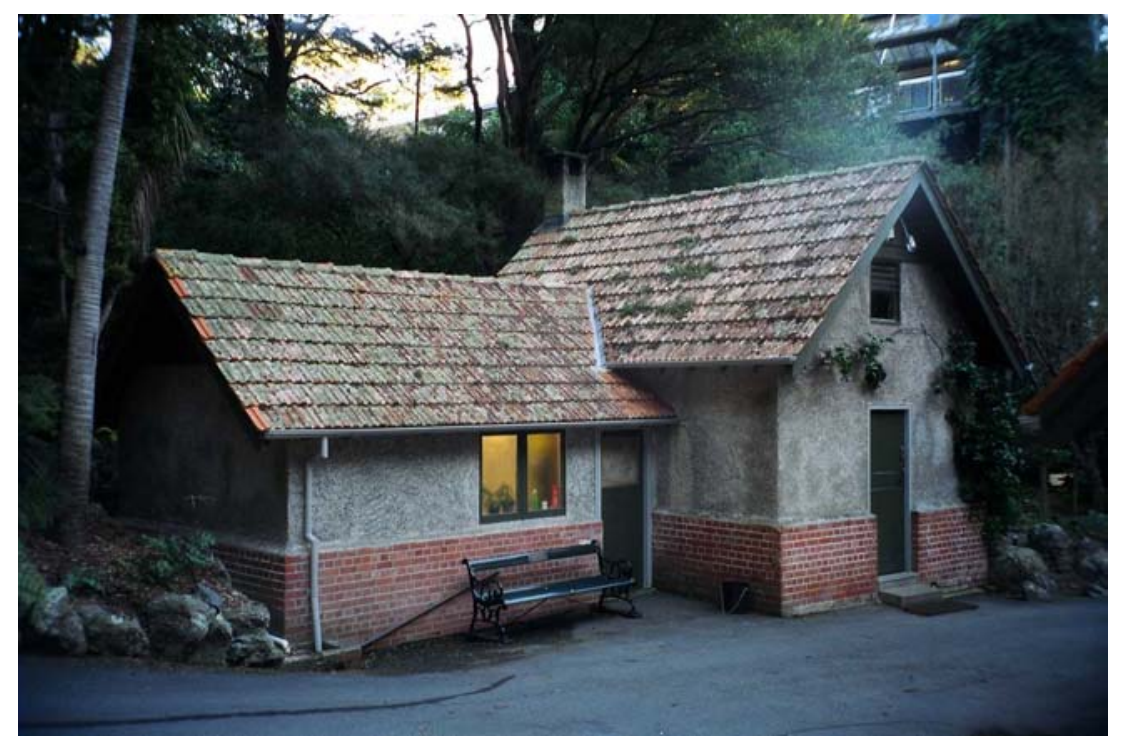

The Mess Room.

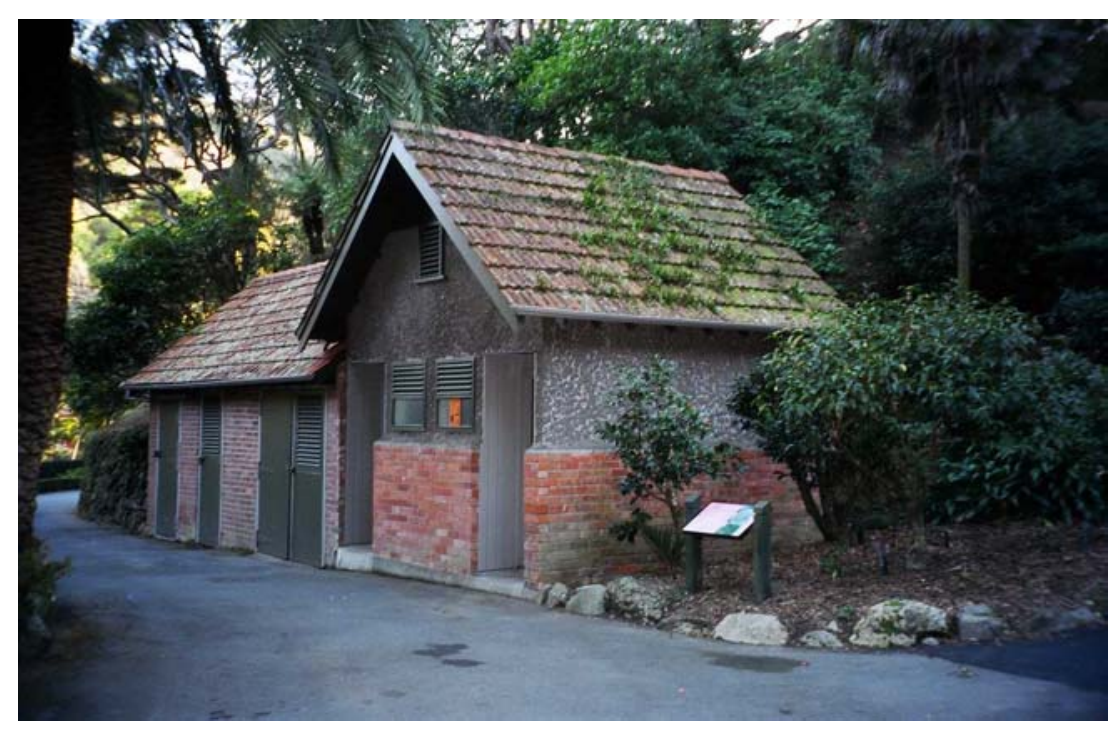

The Stables and Tool Shed. 


\section{Description:}

The Mess Room, Stables and Tool Shed are situated near the Treehouse Interpretive Centre in the sunken garden. They are constructed of red masonry brick in the 'Old English Bond' style with plumb angles and horizontal courses. The heartwood is jarrah and totara, the studs, plates and rafters are Oregon, while all other woodwork is rimu. The gabled roofs are of turtle brand Marseilles tiles which cost f56, with wide matai eaves and rafters. The purloin ends are exposed, and the timber window and door joinery is original. The Mess is L-shaped, with the original chimney and fireplace. One of the Stable stalls has the original clinker brick edgeon-edge flooring. ${ }^{164}$

\section{Architectural Style:}

The architect was the City Engineer, William Morton. Work began on the Mess Room and Stables in early 1915, and they were finished by February or March of that year. ${ }^{165}$ The Mess Hall and Stables are in the Arts and Crafts style. The contractors were Mssrs French and Hampton. ${ }^{166}$

\section{History:}

The first stables in the Botanic Garden were situated one chain north of the site of the current stables, mess hall and tool sheds. ${ }^{167}$ New stables, tool sheds and mess hall were planned in 1911, but were delayed until 1914. ${ }^{168}$

Angus Clyns Sutherland French and William Henry Hampton's tender of $£ 339$ for a Mess, Stables and Bulb Room was accepted, and construction began in early 1915. ${ }^{169}$ Apparently, a potting shed at the Nursery was also built at this time, as it is of similar materials and style. ${ }^{170}$

The Mess Room, Stables and Tool Shed have been in use by Botanic Garden staff ever since. Once horses were no longer used at the Botanic Garden, the Stables became tool sheds. The stable stall that has the original clinker brickwork was used as a movie set a few years ago. ${ }^{171}$ The Mess Hall is still in use by horticultural staff, and the group of quaint buildings is a popular part of the Botanic Garden.

164 Specification for the Erection of Stables, etc, Botanical Gardens, City Engineer, 30 October 1914 (located in WCC File 000205:4:904 - Contract for Construction of Stables and Mess at the Botanical Gardens); Boffa Miskell Ltd with Chris Cochran, Wellington Heritage Building Inventory non-residential buildings 2001 (Wellington: Boffa Miskell, 2001), p. BOTA2.

${ }^{165}$ Boffa Miskell, p. BOTA2; Specification for the Erection of Stables, etc, Botanical

Gardens, City Engineer, 30 October 1914 (located in WCC File 000205:4:904 - Contract for Construction of Stables and Mess at the Botanical Gardens).

${ }^{166}$ Letter from Town Clerk to Mssrs French and Hampton, 30 October 1914; Bond for Performance of Contract, 15 J anuary 1915 (both located in WCC File 000205:4:904 Contract for Construction of Stables and Mess at the Botanical Gardens).

${ }^{167}$ Specification for the Erection of Stables, etc, Botanical Gardens, City Engineer, 30 October 1914 (located in WCC File 000205:4:904 - Contract for Construction of Stables and Mess at the Botanical Gardens).

168 Shepherd and Cook, p. 259.

${ }^{169}$ Specification for the Erection of Stables, etc, Botanical Gardens, City Engineer, 30 October 1914 (located in WCC File 000205:4:904 - Contract for Construction of Stables and Mess at the Botanical Gardens).

170 Shepherd and Cook, p. 259.

${ }^{171}$ Nonda Katsos, personal communication, 30 J une 2003. 


\section{Modification:}

The Mess Hall, Stables and Tool Sheds have been altered internally, but there has been little external modification. ${ }^{172}$

\section{Level of authenticity:}

The Mess Room and Stables demonstrate a high level of authenticity in materials, craftsmanship and design.

\section{Assessment of significance/heritage values:}

\section{Historical}

Despite the prominence of the motorcar by 1915, the Botanic Garden still utilised horses for transport and labour. These stables, which were obviously built to last, demonstrate how important the horse still was in 1915.

The Mess Room and Stables are some of Wellington City Council's longest serving utilities. They have been in constant use since 1915, and are still central to the horticultural management of the Garden today.

The Mess Room, Stables and Tool Shed relate to the Victorian Romantic element that is central to the Botanic Garden. ${ }^{173}$

\section{Architectural}

The Mess Room and Stables have considerable architectural value. They display many elements of Arts and Crafts architecture, and the high quality materials have lasted well and aged admirably. They suit their setting and are popular and very attractive. ${ }^{174}$

The group of buildings sit close to the Treehouse Interpretive Centre, and so are easily accessible to the public.

The theme began by the Mess Room, Stables and Tool Sheds has been continued throughout the Botanic Garden. Red brick is used in the

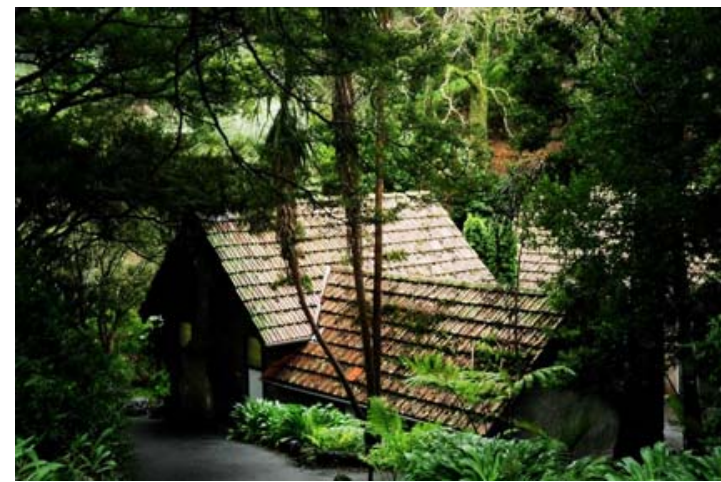

The Mess Room, showing tile roof. public toilets on the Main Drive and the Main Entrance and fences. The rustic look is also suggested by the visitor information stand and map at the Founders Entrance.

\section{Aesthetic}

The Mess Room and Stables have strong public recognition value, and fit beautifully into their setting in the old sunken garden.

\footnotetext{
172 Boffa Miskell, p. BOTA2.

${ }^{173}$ Shepherd and Cook, p. 320

${ }^{174}$ Boffa Miskell, p. BOTA2.
} 


\section{Ladies Rest Room}

The Ladies Rest Room is not recognised by the New Zealand Historic Places Trust or the Wellington City Council District Plan.

Map reference (6)

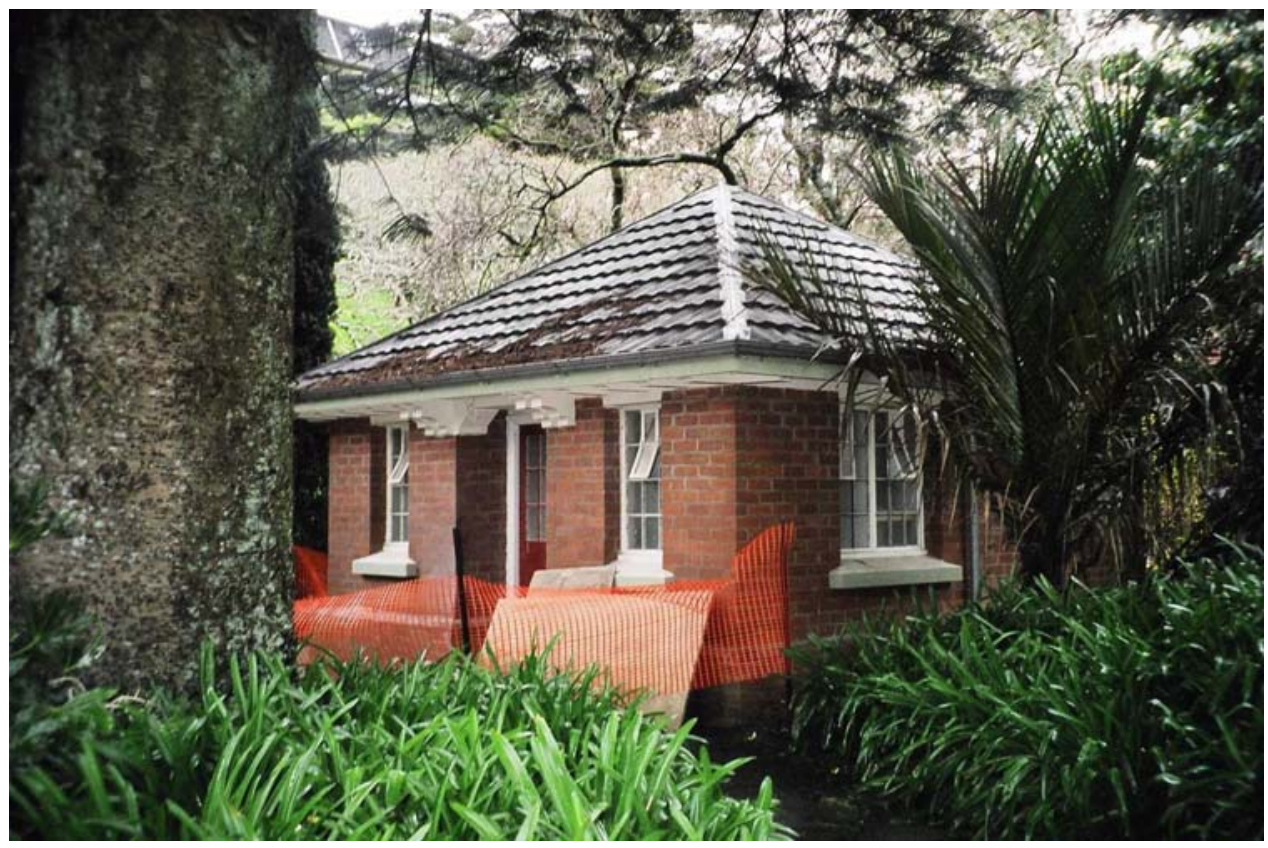

The Ladies Rest Room, Main Garden.

\section{Description:}

The Ladies Rest Room is a red brick toilet block constructed in $1929 / 1930$. It is located on William Bramley Drive.

\section{Architectural Style:}

The Ladies Rest Room is constructed of red masonry brick, with totara timber joinery. ${ }^{175}$ The roof is grey tile. The windows are mullioned.

\section{History:}

Before 1902, public facilities at the Botanic Garden were very basic. Running water was supplied to the Children's Play Area in 1905, as there had previously only been a dirty creek for the children to drink from. ${ }^{176}$

175 Wellington City Corporation, Specification and General Conditions, Contract No 1405:

Contract for Erection of Conveniences for Males, Nairn Street Reserve and Ladies Rest Room Botanical Gardens, Wellington. 8 November 1929, (located in WCC file 00009:341:11/39Contract No 1405 Male Conveniences Nairn St Reserve: Ladies Rest Room: Botanical Gardens, General Files).

${ }^{176}$ Shepherd and Cook, p. 243. 
Earth closets were provided for women visitors to the Garden in 1905, and men's toilets were built by Mssrs McLean and Gray for f144 in 1915. McLean and Gray again constructed a brick Ladies Rest Room in 1929, replacing the wooden structure on the Main Drive. ${ }^{177}$ McLean and Gray also constructed public toilets at Nairn Street at this time, and they tendered the construction of both for f950.1.9. ${ }^{178}$ Chemical toilets were installed in the Ladies Rest Room in 1948. ${ }^{179}$ The Botanic Garden toilet block still stands, and has recently been upgraded.

\section{Modification:}

Chemical toilets were installed in 1948, and the building has just undergone a refit.

\section{Assessment of significance/heritage values:}

\section{Historical}

The ladies restroom has been used for its original purpose since 1929.

\section{Architectural:}

The Ladies Rest Room relates to other features in the Main Garden, for example the Mess Room and Stables and the Main Gates, as it is also constructed of red brick. The small multi-paned windows are also in common with other buildings in the Botanic Garden.

\footnotetext{
177 Shepherd and Cook, p. 245.

178 Wellington City Corporation, Specification and General Conditions, Contract No 1405

179 Shepherd and Cook, p. 243.
} 


\section{The Norwood Begonia House/Lily House/Teahouse}

The Norwood complex is not recognised by the New Zealand Historic Places Trust or the Wellington City Council District Plan

Map reference (7)

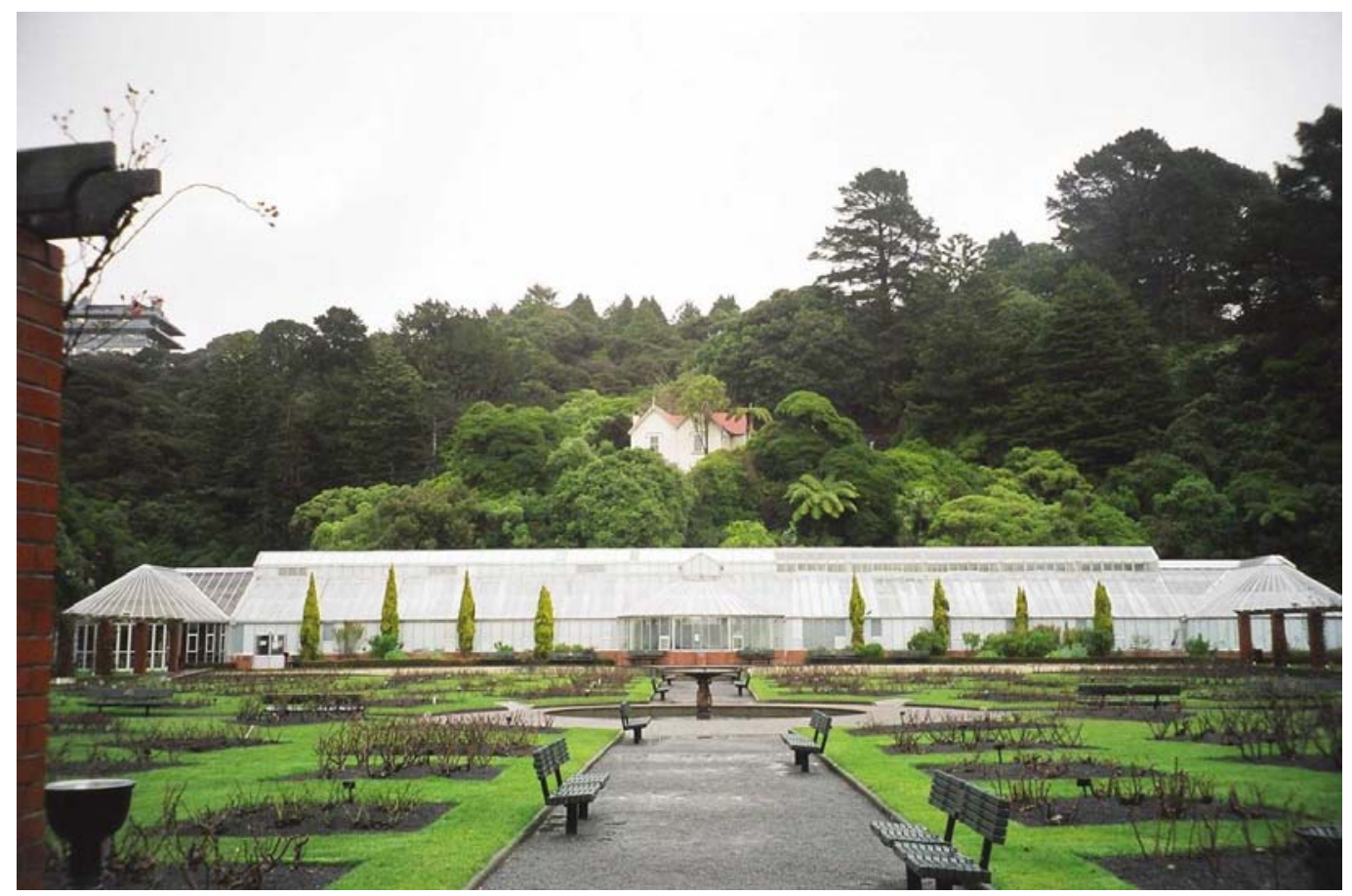

The Lady Norwood Begonia House complex.

\section{Description:}

The Begonia House, Lily House and Teahouse are part of the Lady Norwood Rose Garden complex. The Begonia House provides both a tropical house and greenhouse, with displays of orchids and other tropical plants.

\section{Architectural Style:}

Wellington City Council designed the Begonia House, and it was completed in 1960. The glasshouse is constructed of glass and steel and is of a traditional greenhouse design. ${ }^{180}$

The Teahouse is in the same style as the Begonia House, but is lower and smaller. It is built of glass and aluminium. ${ }^{181}$ The architect was Paul Lenihan of the Wellington City Council. ${ }^{182}$

180 Kernohan, David, Wellington's Old Buildings (Wellington: Victoria University Press, 1994), p. 230.

${ }^{181}$ David Kernohan, Wellington's New Buildings (Wellington: Victoria University Press, 1989), p. 230.

182 Kernohan, Wellington's New Buildings, p. 211. 
The Lily House was added in 1990. It balances the Teahouse and is attached to the further end of Begonia House.

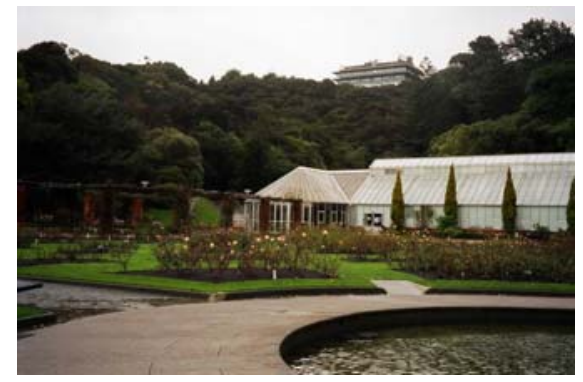

The Lady Norwood Teahouse

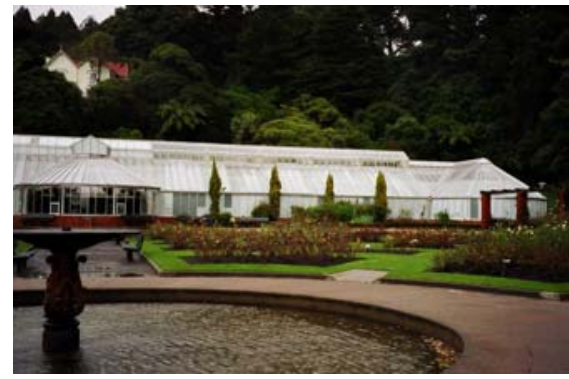

Lady Norwood Lily House.

\section{History:}

Begonias have been a popular feature of the Botanic Garden since about 1913, when they were displayed in the Propagating House. The need for a hothouse for a winter garden was recognised by the 1920s, however funding was a problem. Lady Norwood's donation of $£ 200$ towards extending the Propagating House in 1939 was the first of many donations towards the Lady Norwood Rose Garden area. ${ }^{183}$ The Begonia House was donated to the city by former Mayor Sir Charles Norwood in December of 1960. The Begonia House displays over 300 species of plants under $120 \mathrm{~m}^{2}$ of Belgian glass. ${ }^{184}$

The Norwood family donated what is now the Teahouse to Wellington city in 1981. ${ }^{185}$ The Lily House was added in 1990.

\section{Assessment of significance/heritage values:}

\section{Architectural}

The Begonia House's architecture is based on traditional greenhouse design. The long low glass building is closely related to the greenhouses at the Royal Botanic Garden at Kew. The Temperate House at Kew even has two smaller additions to the ends, roles that the Teahouse and Lily House fulfil in Wellington's Botanic Garden. ${ }^{186}$

The Norwood Begonia House also fulfils a function in relation to the Lady Norwood Rose Garden. The traditional greenhouses complete the formal atmosphere of the Lady Norwood Rose Garden.

\footnotetext{
183 Shepherd and Cook, pp. 285, 287.

${ }^{184}$ Kernohan, Wellington's Old Buildings, p. 230.

185 Shepherd and Cook, p. 251.

${ }^{186}$ Hepper, p. 66.
} 


\section{Features of the Botanic Garden:}

\section{Urns}

The urns are not recognised by the New Zealand Historic Places Trust or the Wellington City Council District Plan

Map reference (8)

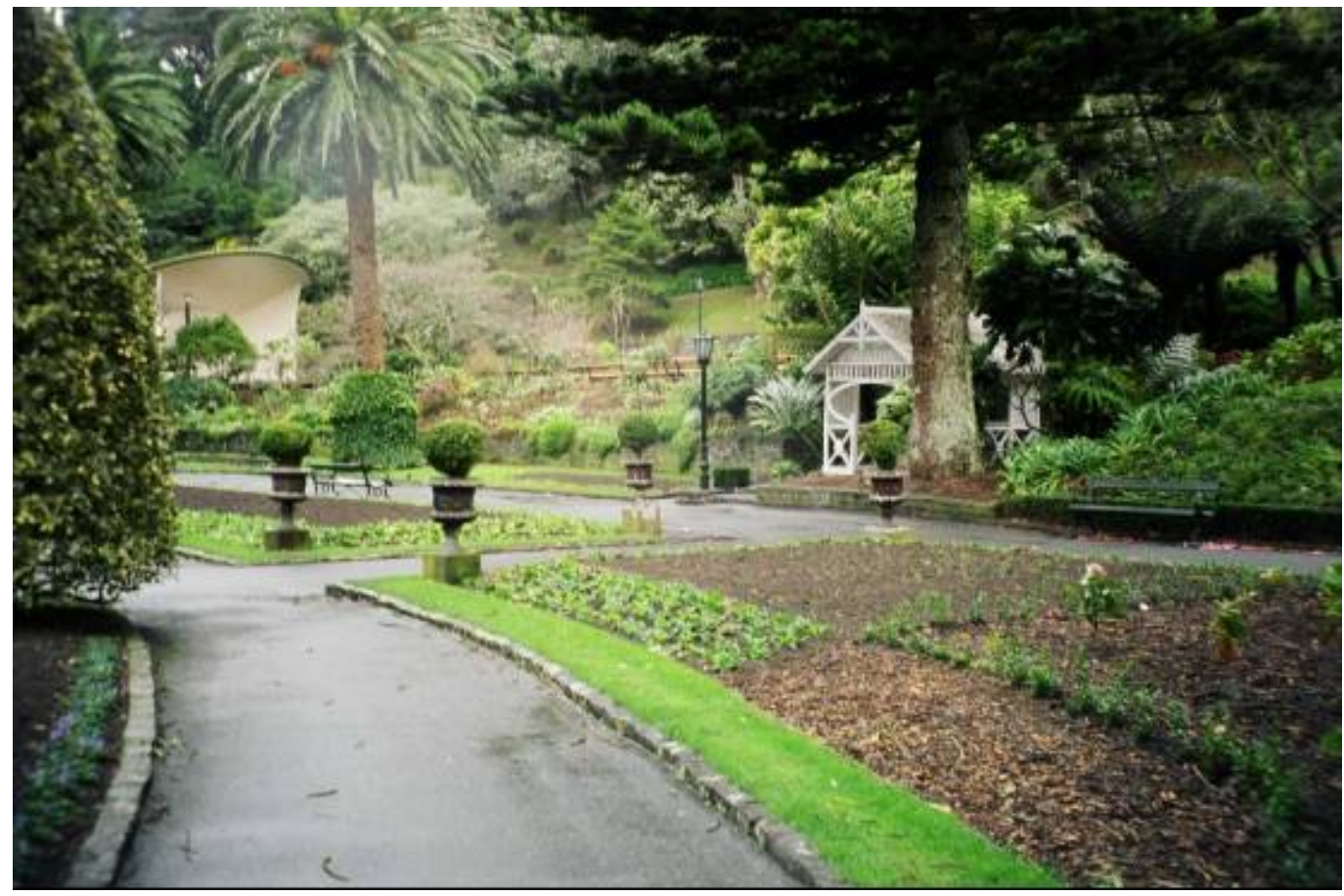

Four ceramic urns.

\section{Description:}

Six ceramic urns in a classical style, decorated with vines and grapes and scallop shapes. The bronzed effect comes from aventurine, which crystallises during firing.

\section{History:}

The three pairs of urns arrived in the Botanic Garden between 1906 and 1910. It is possible that the urns were made locally, possibly at Hutsons in Wallace Street. ${ }^{187}$

\section{Modification:}

A layer of cement has been added to several of the urns to glue them together after the tops have been knocked off their plinths/ bases.

Some of the original urns have been damaged/ destroyed and have been replaced with fibreglass copies. ${ }^{188}$

187 Shepherd and Cook, p. 322.

188 Mike Oates, personal communication, 12 August 2003. 


\section{Assessment of significance/heritage values:}

\section{Historical}

The urns have been a long-standing feature of the Botanic Garden for nearly 100 years, and relate to the Victorian feel of the Main Garden and Founders Entrance area. They were formerly used to hold cabbage trees, historically a key feature of the Botanic Garden's Main Garden.

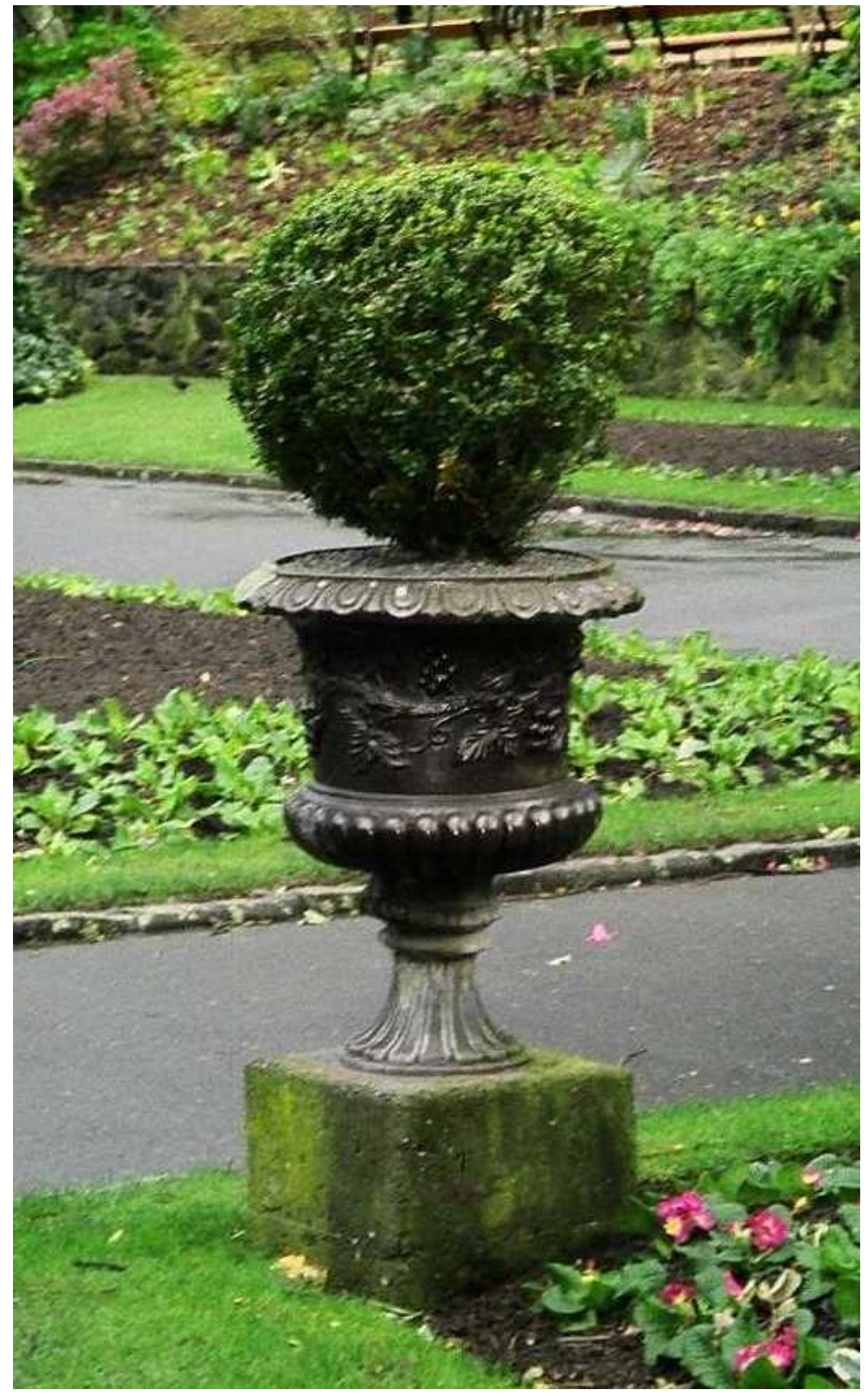

Close up of ceramic urn 


\section{Children with water ewers}

The children with water ewers are not recognised by the New Zealand Historic Places Trust or the Wellington City Council District Plan

Map reference (9)

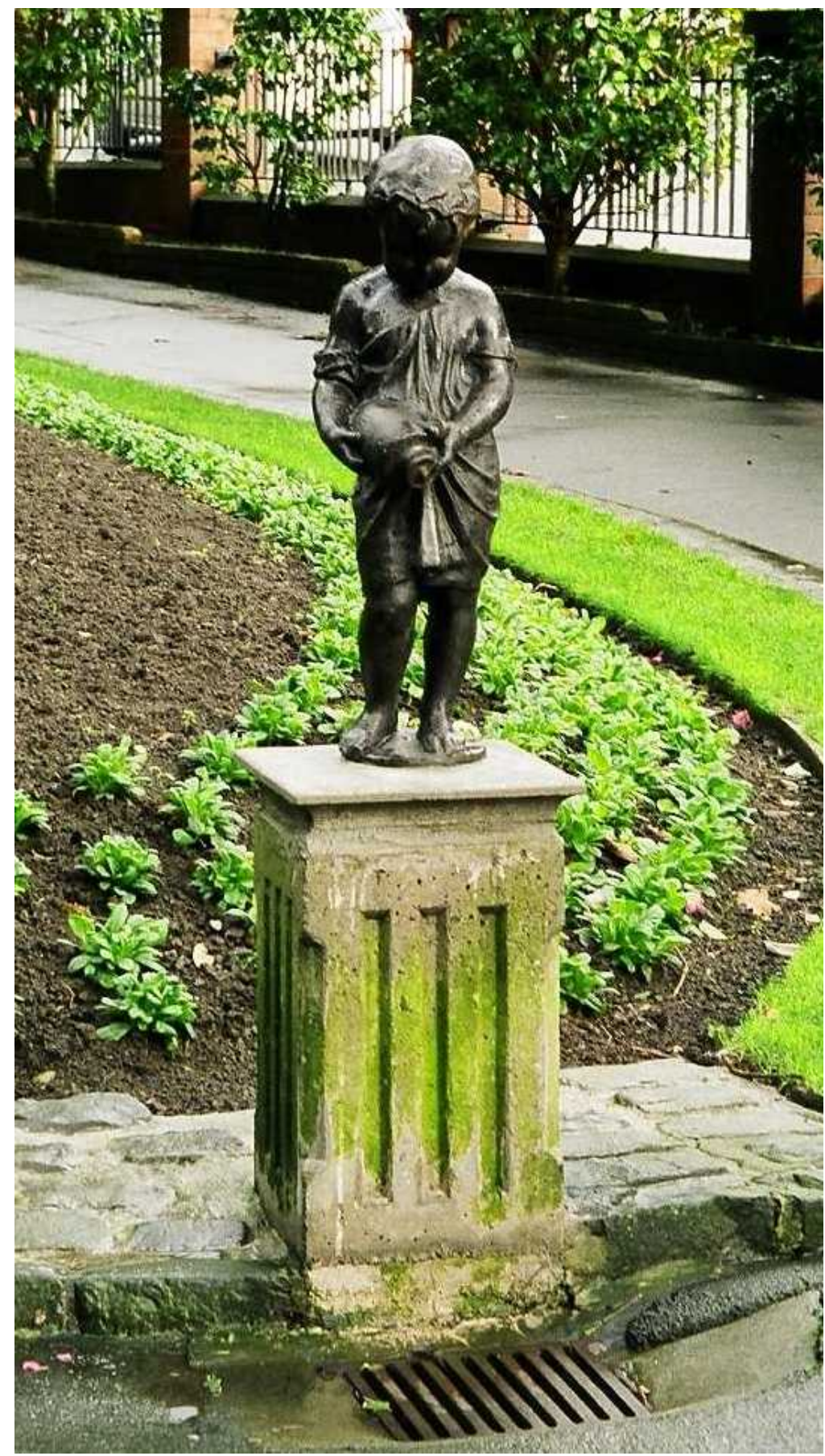

Little boy with water ewer. 


\section{Description:}

The statues are of a child pouring water from an ewer. They are bronze (the originals are cast iron). They can also be used as fountains, but are not regularly used as such.

\section{History:}

The pair of children bearing ewers arrived in the Botanic Garden between 1906 and 1910. ${ }^{189}$

\section{Modification:}

The statues were stolen a few years ago, but were eventually returned after an appeal by the staff at the Botanic Gardens. When the statues were returned, copies were made and cast in bronze. These copies remain in the Botanic Garden, while the original statues are in safekeeping. ${ }^{190}$

\section{Assessment of significance/heritage values:}

\section{Historical}

The statues have been a feature of the Botanic Garden for nearly 100 years, and relate to the Victorian feel of the Main Garden and original 13 acres.

189 Shepherd and Cook, p. 322.

190 Mike Oates, personal communication, 12 August 2003. 


\section{Annie's Seat}

Annie's Seat is not recognised by the New Zealand Historic Places Trust or the Wellington City Council District Plan

Map reference (10)

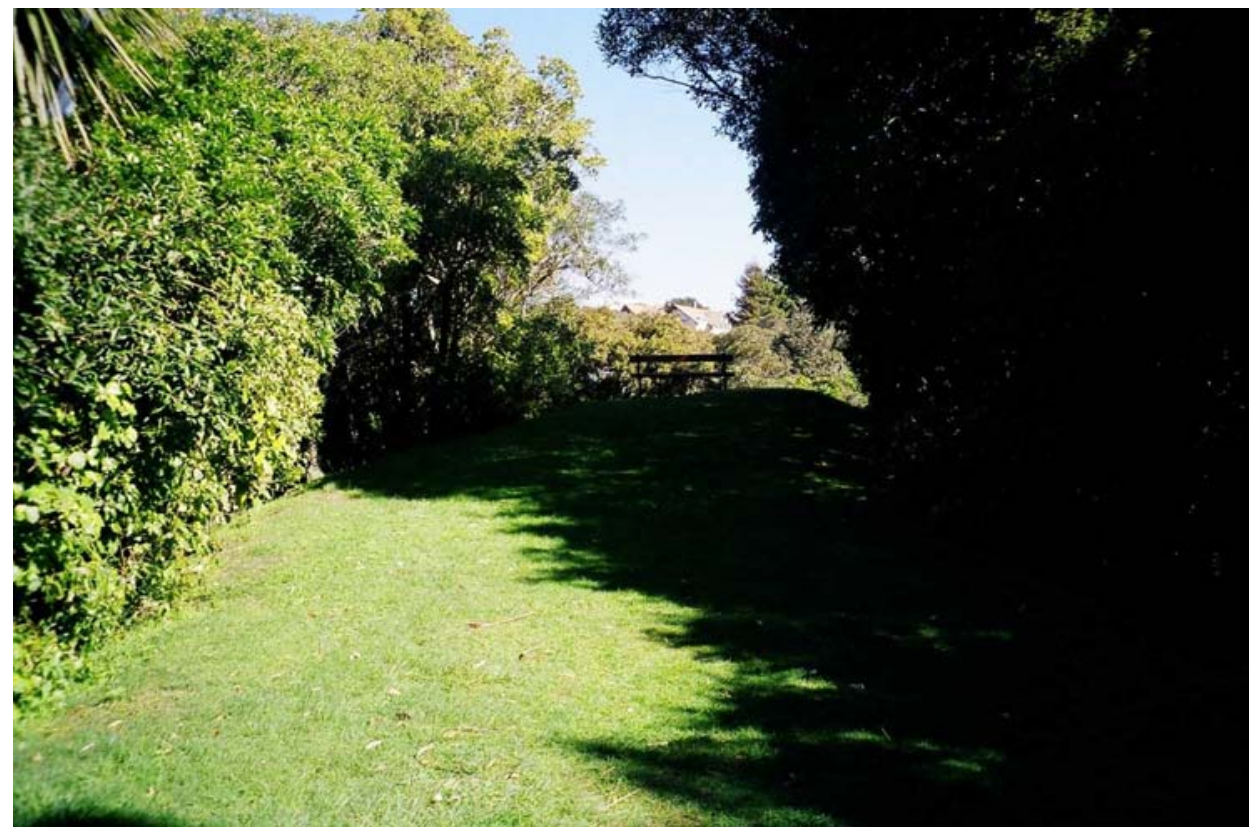

Annie's Seat.

\section{Description:}

Annie's seat is a feature of the Botanic Garden. A garden seat marks the site.

\section{History:}

Annie's Seat marks the spot where Annie Bramley, wife of the first Keeper William Bramley, used to sit and watch her husband work in the nursery. The Bramleys lived at the Garden for over 18 years. The spot has been known as Annie's Seat since about 1875. ${ }^{191}$

The site is currently not marked on the Wellington Botanic Garden, incorporating Bolton Street Memorial Park, pamphlet available to visitors to the Garden. However, a garden bench still marks the site.

\section{Assessment of significance/heritage values}

\section{Historical:}

Annie's Seat is an old feature of the Botanic Gardens, which indicates the lives of the people and families

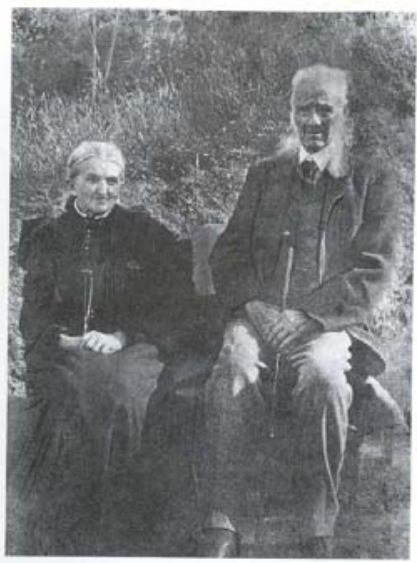

William and Annie Bramley [Source: Shepherd and Cook, p. 49]. who lived and worked in the Gardens.

${ }^{191}$ Shepherd and Cook, pp. 60-61. 


\section{Historic Path Names:}

\section{William Bramley Drive}

Map reference (11)

William Bramley Drive is one of the main paths of the Botanic Gardens and links the Founder's Entrance to the Duck Pond. William Bramley (1819-1908) was Keeper of the Gardens from 1870 to 1889 . He, his wife and his family of seven children lived at the Botanic Garden during this time. Mr Bramley was born in England and immigrated to New Zealand with his wife Annie. ${ }^{192}$

\section{Ludlam Way}

Map reference (12)

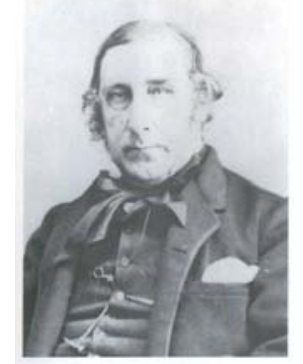

Alfred Ludlam [Source:

Shepherd and

Cook, p. 183].

Ludlam Way is another main path from the Founder's Gates. Alfred Ludlam (1810-1877) was a founder member of the Wellington Horticultural Society and later Governor and Secretary of the New Zealand Institute. Ludlam was a member of the House of Representatives, and was responsible for introducing the Botanic Garden Bill into Parliament. He was appointed the first Treasurer of the Botanic Gardens Board, and worked closely with William Bramley and J ames Hector in laying out the Garden. He contributed many plants to the Botanic Garden from his own garden, and also visited Australia to procure plants. ${ }^{193}$

\section{Buchanan Way}

Map reference

(13)

Buchanan Way now links the Treehouse Interpretive Centre to the Founder's Gates. John Buchanan (1819-1898) was a draughtsman and botanical collector for the Otago Provincial Geological Survey from 1863, and worked with James Hector. When Hector moved to Wellington to join the Colonial Museum and Geological Survey, Buchanan joined him as a draughtsman and botanist. Buchanan produced an inventory of every plant in the Botanic Garden in 1875, which is an invaluable resource as it describes the existing native bush. Buchanan became the botanical advisor and unofficial overseer of work at the Botanic Garden in about 1873. He was also made a Fellow of Linnean Society in recognition of his work with botany in New

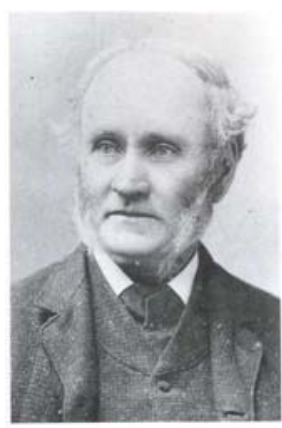

J ohn Buchanan

[Source: Shepherd and Cook, p. 189].

192 Shepherd and Cook, pp. 49, 189-90.

193 Shepherd and Cook, pp. 182-3.

194 Shepherd and Cook, pp. 188-9. 


\section{William Wakefield Way}

Map reference (14)

William Wakefield Way links the West Entrance to the Treehouse Interpretive Centre. Colonel William Wakefield was the Principal Agent for the new colony of New Zealand and followed the directions of the New Zealand Company to ensure that the settlement had a large green belt and space for a botanic garden. Wakefield was also involved in horticulture, and was the first president of the Wellington Horticultural Society. ${ }^{195}$

Myrtle Way (15), Grass Way (16), Mamuku Way (17), Manuka Way/Manuka Path (18), Camellia Path (19) refer to the plants which used to, or still, line the paths.

\section{Kew Way}

Map reference (20)

Kew Way links the Glen Entrance to the children's play area. Kew Way refers to the Royal Botanic Garden at Kew, which was an inspiration to the creators of the Wellington Botanic Gardens. The Royal Botanic Garden at Kew was an authority in establishing colonial botanic gardens, and produced instructions about how to label plants and instructions about exchanging and distributing plants to other botanical gardens. The Royal Botanic Garden at Kew encouraged a uniform approach to colonial botanic gardens. The Wellington Botanic Garden had a strong relationship with Kew, for example Hector and the J.D. Hooker, Director of the Royal Botanic Garden at Kew, corresponded and Hooker sent rhododendrons and conifer seeds for the Botanic Garden. The Wellington Botanic Garden also sent plants and seeds to Kew. ${ }^{196}$

Rocky Way/Rock Path (21) runs through the Hector Pinetum and refers to the terrain.

J unction Path/J unction Way (22), Glenbervie Entrance and Path (23), East Path (24), West Way (25), Pine Hill Path (26) refer to entrance ways and paths in the Garden.

Serpentine Way (27) runs from the Lady Norwood Rose Garden to Pine Hill Path. The Overseer's Cottage is on this path. Presumably it is named so because of the way it twists and turns its way down the slope. This name dates from the 1870s. ${ }^{197}$ There is also a Serpentine Path at the Royal Botanic Garden at Kew. ${ }^{198}$

Norwood Path (28) is named after Sir Walter Norwood and his family who have been generous benefactors to the Botanic Garden. This path links the Lady Norwood Rose Garden to the East Entrance. ${ }^{199}$ (Please see the entry on the Lady Norwood Rose Garden. )

\footnotetext{
195 Shepherd and Cook, pp. 17, 19, 21, 199.

196 Shepherd and Cook, pp. 67, 196.

${ }^{197}$ J udy Siers with Winsome Shepherd, The Botanic Garden: A Celebration of a Garden (Wellington: Culture and Recreation Division, Wellington City Council, 1992), p. 16.

198 Hepper, p. 2.

199 Shepherd and Cook, p. 5.
} 
Gorse Path (29) refers to the many problems with gorse the Botanic Garden has experienced since 1870. The Gorse Path runs from the Cable Car to join Kew Way.

Druid Hill (30) was named by the Botanic Garden Board in 1875. It is named after the tree worshipping priests of the Britain and Gaul and the name seems appropriate as Druid Hill is situated amongst the pines. ${ }^{200}$

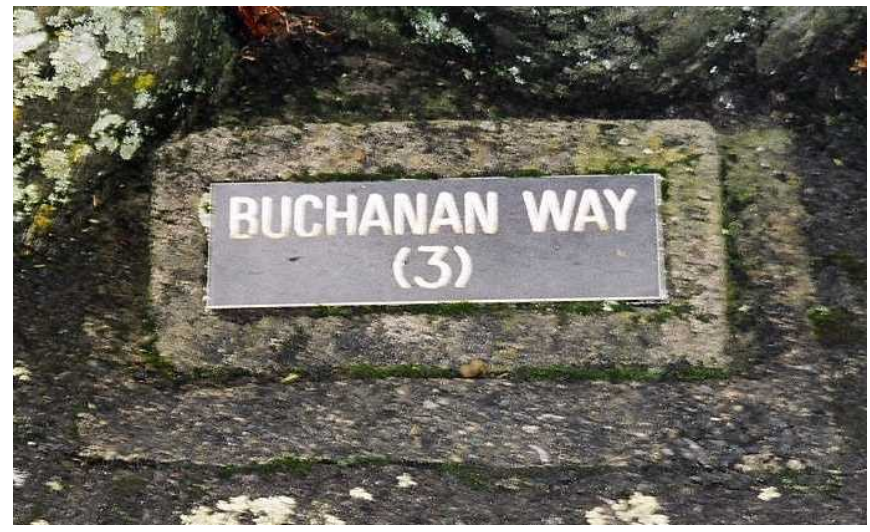

An example of the historic path names.

\section{Assessment of significance/heritage values}

\section{Historical:}

The historic path names are an important element of the Botanic Garden. They recognise the history of the Garden and the people who devoted their time to establishing the Garden as a treasure for Wellington City and New Zealand. The paths named after plants also provide a link to the horticultural past of the Garden, as they describe plants that may no longer survive in the Garden.

${ }^{200}$ Shepherd and Cook, p. 60. 


\section{Joy Fountain}

The J oy Fountain is not recognised by the New Zealand Historic Places Trust or the Wellington City Council District Plan

Map reference (31)

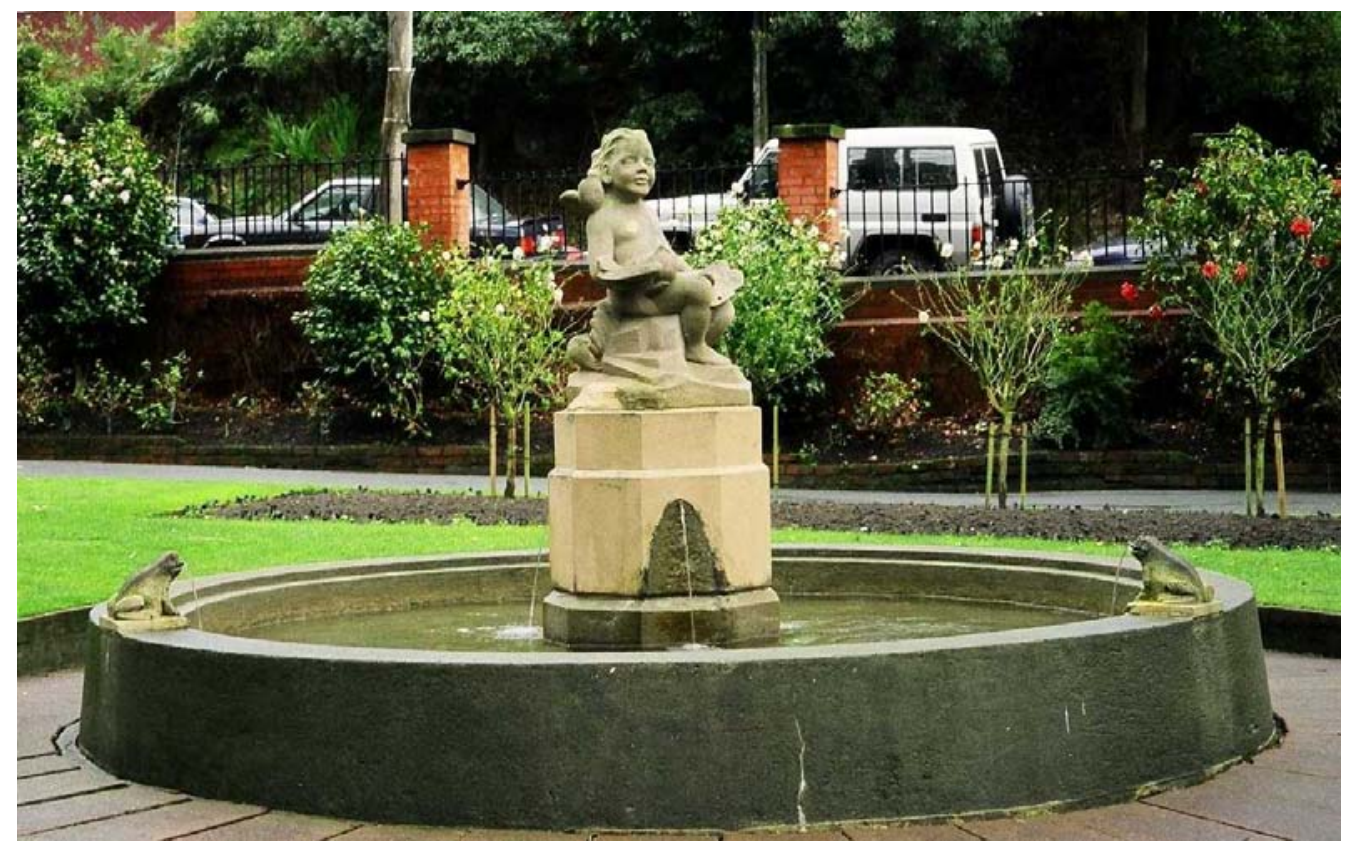

The J oy Fountain.

\section{Description:}

The J oy Fountain is a statue, fountain and circular pool which sits between William Bramley Way and Ludlam Way. The central figure is a boy holding pigeons. Two frogs flank the pool. The statue, 'J oy' is made of Hinuera stone. ${ }^{201}$

\section{Architectural Style:}

Shepherd and Cook describe the statue as European Art Deco with Classical elements. ${ }^{202}$ The artist felt that the circular pool allowed 'greater freedom of rhythm to his conception' than the originally planned octagonal pool. ${ }^{203}$

\section{History:}

The J oy Fountain came about though the Martin J ames Kilgour bequest. Mr Kilgour donated $£ 100$ to the city in 1930 for a piece of statuary for the Botanic Garden. He stated in his will that the statuary 'had to be erected or placed as near as possible to the Main Gates' of the Botanic Garden. ${ }^{204}$ Director of the Garden, J.G. MacKenzie suggested a design for a fountain and basin, which was rejected by the

${ }^{201}$ Shepherd and Cook, p. 328.

202 Shepherd and Cook, p. 328.

203 Memo 31/ 21/ 7 from K. E. Luke, City Engineer, to Town Clerk, 5 November 1945 (located in WCC file 00001:631:20/ 30 - Statue 'J oy' Botanical Gardens).

204 Letter from Assistant District Public Trustee to Town Clerk, 7 May 1930 (located in WCC file 00001:631:20/ 30 - Statue 'J oy' Botanical Gardens). 
City Council solicitor as he believed that it did not meet the terms of the bequest. The design by Mr Ellis, Art Master at the Technical College, was still MacKenzie's selection, and he spent four years trying to find someone to sculpt the design. The Second World War intervened and in 1940-41 a site was selected for the proposed statuary. In 1942, Alex R. Fraser, A.R.D.A. was contracted by the City Engineer to sculpt another work - 'J oy'. Due to increased work demands during the war, Fraser did not complete the sculpture until 1945. The pool was completed by the City Engineer's Department, and the sculpture was finally fixed in place in December 1946. The statue, pool and fountain came to cost five times the amount of the Kilgour bequest. ${ }^{205}$

\section{Level of authenticity:}

There has been little or no modification since 1946, and the statue of 'J oy' is beginning to deteriorate.

\section{Assessment of significance/heritage values:}

\section{Historical}

The 'J oy' fountain pool has been a popular and pleasant spot near the Founders Entrance of the Garden for visitors since 1946.

${ }^{205}$ Shepherd and Cook, pp. 326-8. 


\section{Lady Norwood Rose Garden Fountain}

The Lady Norwood Rose Garden Fountain is not recognised by the New Zealand Historic Places Trust or the Wellington City Council District Plan

Map reference (32)

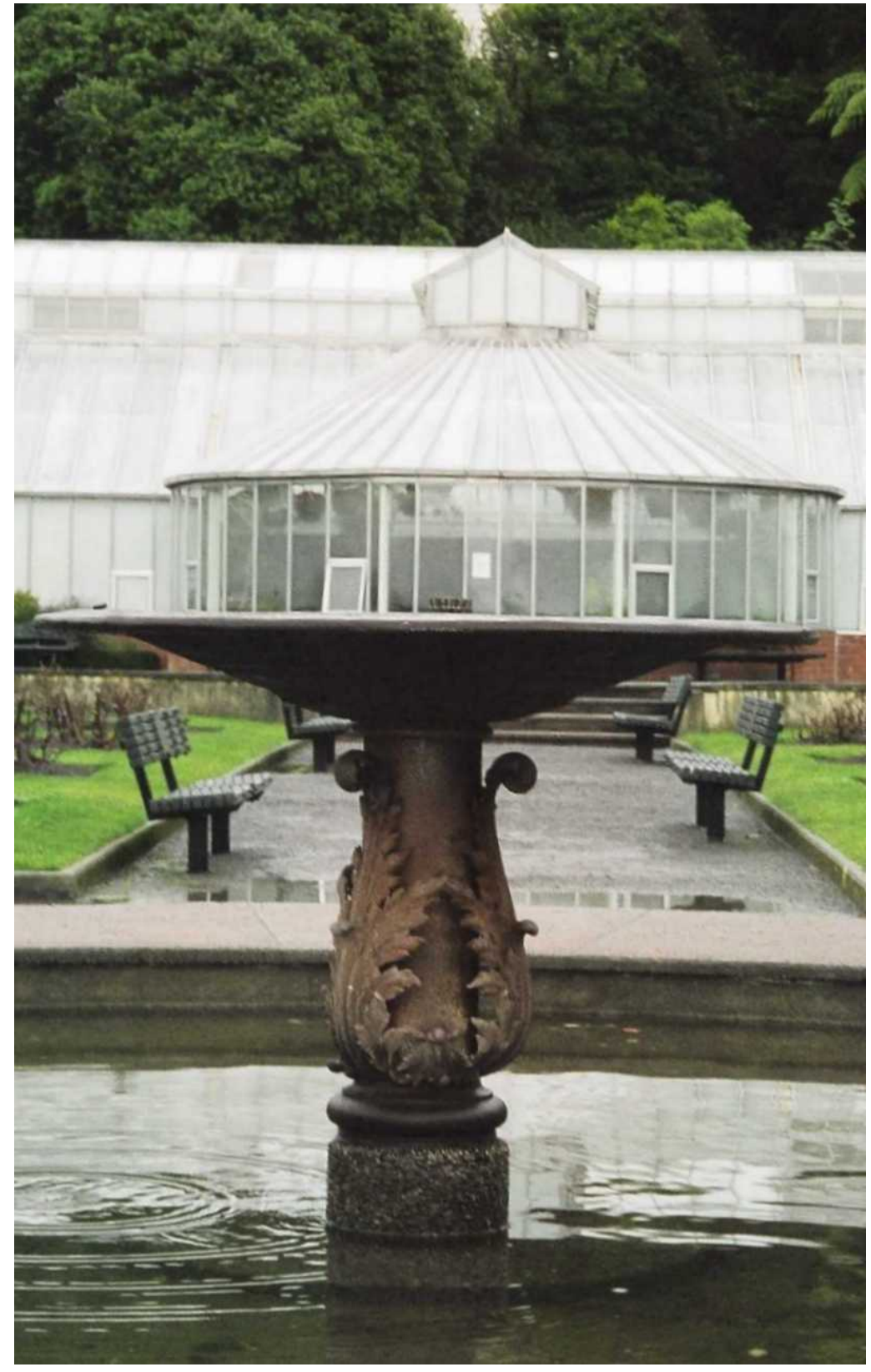

The Lady Norwood Rose Garden Fountain.

\section{Description:}

The Lady Norwood Rose Garden Fountain is an antique bronze fountain donated by the Norwood in 1977 to replace the fountain donated by Lady Norwood in 1956. The fountain sits in a pool in the centre of the Rose Garden. 


\section{Architectural Style:}

The fountain is bronze, and has typical Arts and Crafts motifs such as agapanthus leaves.

\section{History:}

Little is known about the fountain, other than that it originally stood outside a London bank, and found its way to New Zealand via Melbourne. It is estimated to be about 130 years old. 206

\section{Level of authenticity:}

The fountain maintains high design and material authenticity.

\section{Assessment of significance/heritage values:}

\section{Historical:}

The fountain is 130 years old, and has an interesting, if mysterious, history.

\section{Architectural}

Like the Begonia and Lily Houses, the fountain relates to the Victorian design of the areas surrounding the Main Garden. It also connects to the Lady Norwood Rose Garden's formal design.

206 Tritenbach, p. 76; Kernohan, Wellington's Old Buildings, p. 230; Shepherd and Cook, p. 289. 


\section{Main Entrance Gates}

Wellington City Council District Plan

The Main Entrance Gates are not recognised by the New Zealand Historic Places Trust

Map reference (33)

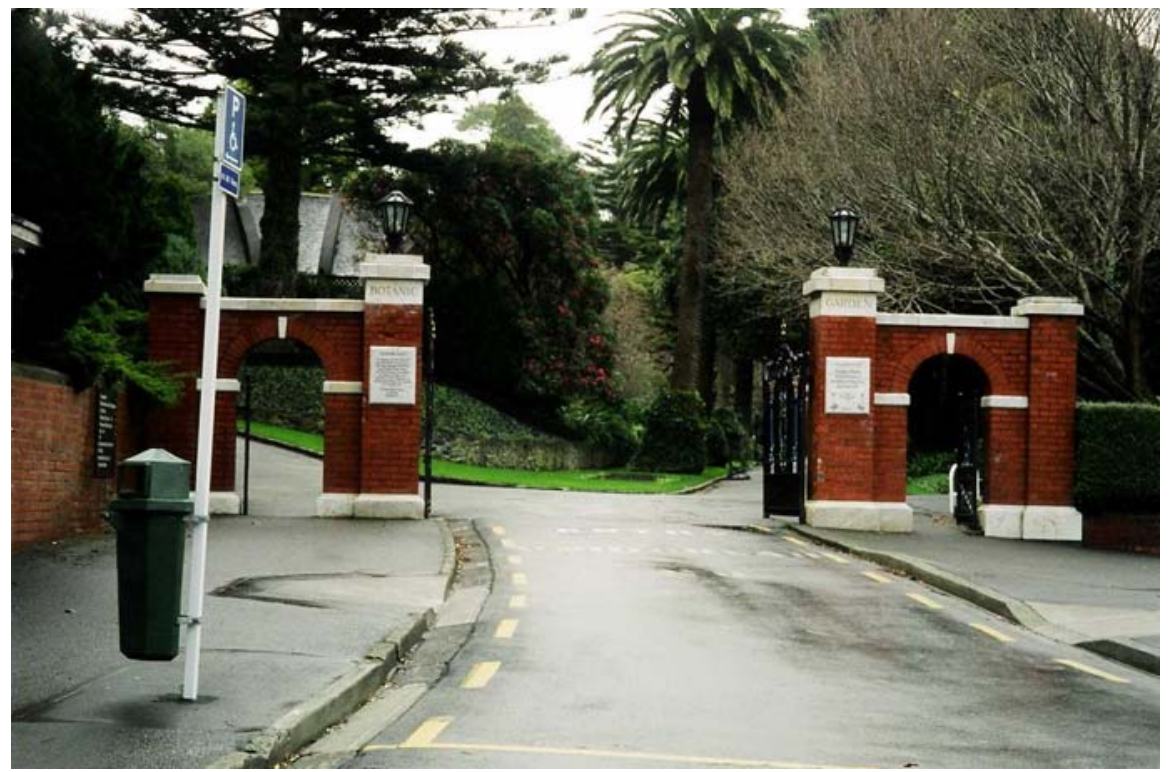

The Founder's Entrance.

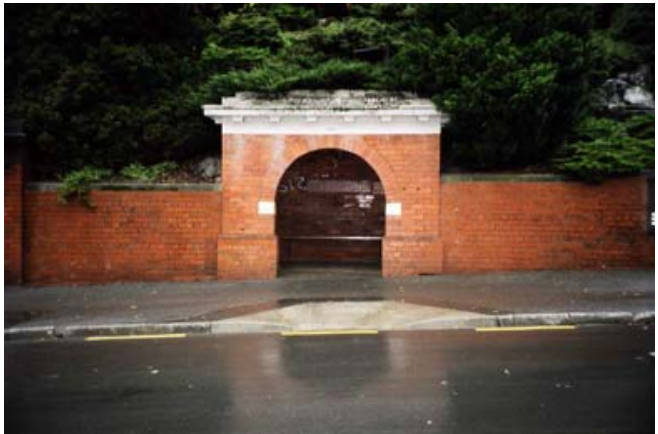

Bus shelter at Founder's Entrance of the Botanic Garden

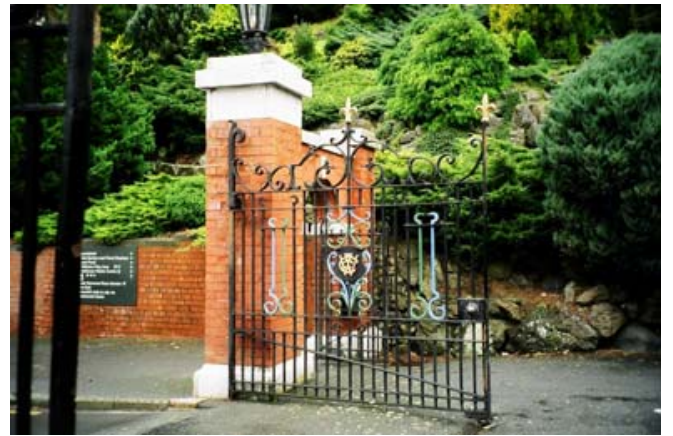

Detail of the Founder's Entrance Gates.

\section{Description:}

The Main Gates of the Botanic Garden are constructed of red brick pillars and wrought iron gates. The gates are decorative and incorporate the WCC of the Wellington City Corporation (now Council). 


\section{History:}

The first Main Gates for the Botanic Garden were wooden and were erected in $1878 .{ }^{207}$ These gates were replaced in 1925, when wrought iron gates were bought from the Wellington Hospital Board. The brick pillars were constructed by Mssrs Hickmott and Sons. ${ }^{208}$ The brick bus/tram shelter was also constructed in 1925 by R.S Anyon. ${ }^{209}$

The Main Entrance was renamed Founders Gate in 1991 as part of the centennial celebrations of the Vesting Act. Plaques were erected recognising the Botanic Garden Board and their role in establishing the Botanic Garden. The plaques were unveiled by descendants of J ames Hector and Thomas Mason. ${ }^{210}$ A further entrance, the Centennial Entrance, was formed in 1990 and leads to Anderson Park and the Lady Norwood Rose Garden.

\section{Level of authenticity:}

High level of authenticity in regard to materials and craftsmanship.

\section{Assessment of significance/heritage values:}

\section{Historical:}

The Main Gates have a long history in Wellington, having originally belonged to the Hospital Board.

The Main Gates are the public face of the Garden and are closely related to the Botanic Garden. They also relate to the Victorian Main Garden.

\footnotetext{
207 Shepherd and Cook, pp. 55, 239.

208 Shepherd and Cook, p. 262.

${ }^{209}$ Shepherd and Cook, p. 245.

${ }^{210}$ Shepherd, Wellington's Heritage, p. 223.
} 


\section{Spaces in the Botanic Garden:}

\section{Lady Norwood Rose Garden}

The Lady Norwood Rose Garden is not recognised by the New Zealand Historic Places Trust or the Wellington City Council District Plan

Map reference (34)

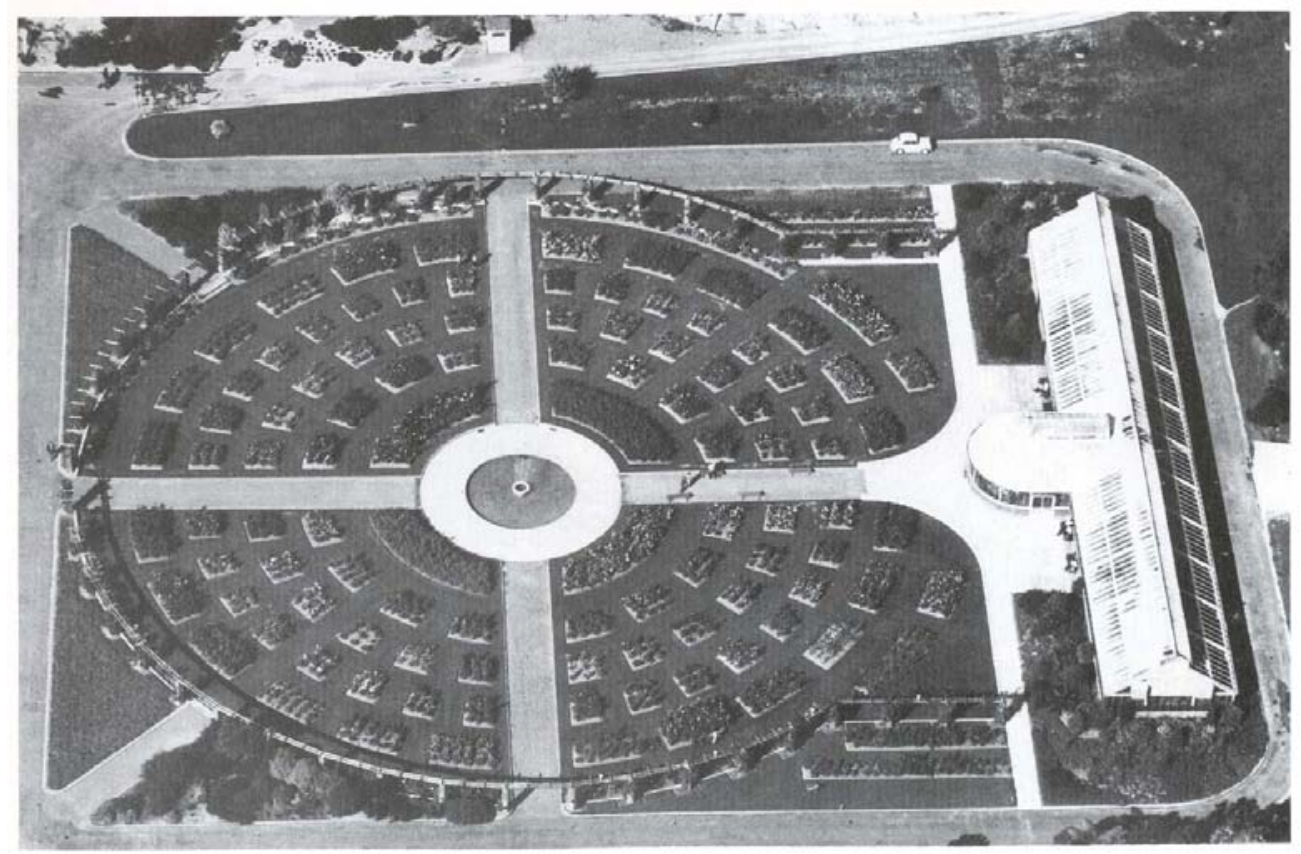

Aerial view of the Lady Norwood Rose Garden, illustrating formal parterre design [Source: Shepherd and Cook, p. 319].

\section{Description:}

The Lady Norwood Rose Garden is a traditional rose garden with over 3000 roses of 300 varieties. It is 1.21 ha of formal bedding and paths. ${ }^{211}$

\section{Architectural Style:}

The Lady Norwood Rose Garden is set out in a formal geometrical style, influenced by nineteenth century parterre.

\section{History:}

The site on which the Lady Norwood Rose Garden is situated is one of the most modified areas in the Garden. The site was originally part of Honeyman's Gully and the Waipiro (Waipirau) stream used to run through this valley. It is also part of the Wesleyan Land bought back in 1865 (please see History). ${ }^{212}$

${ }^{211}$ Wellington City Council, p. 44.

212 Shepherd, unpublished source, p. 27. 
Work on the Lady Norwood Rose Garden was begun in 1950, and by 1953 the garden was designed and planted. The Rose Garden was named after Lady Norwood 'in appreciation of the services rendered to the city by herself and Sir Charles' ${ }^{213}$ The pergola was added in 1961. A statue (please see entry on Lady Norwood Garden Statue) was donated by Lady Norwood in 1956, but was later replaced in 1977 by the Norwood Family. ${ }^{214}$

The Botanic Garden's original rose garden was on the site of what is now the Sound Shell Lawn. The area was known as 'the Rosary' and existed from around 1910 to 1953 when the Sound Shell was erected. ${ }^{215}$

The Rose Garden itself is influenced by nineteenth century garden design. The Rose Garden in geometrical in style, with 'a circular sunk parterre' where the roses are planted. Circular designs for rose gardens were traditional and common in both the United Kingdom and New Zealand. The design is similar to one by James Young in the 1930s. The size and openness of the Lady Norwood Rose Garden is suggestive of nineteenth century parterre. Walter Cook remarks that the Lady Norwood Rose Garden 'achieves the public and extrovert character which expresses the original purpose and function of the classical formal garden'. 216

The Begonia House was opened in 1960, the Tea House in 1982 and the Lily House in 1990 (please see separate entry on these buildings).

The Lady Norwood Rose Garden is one of New

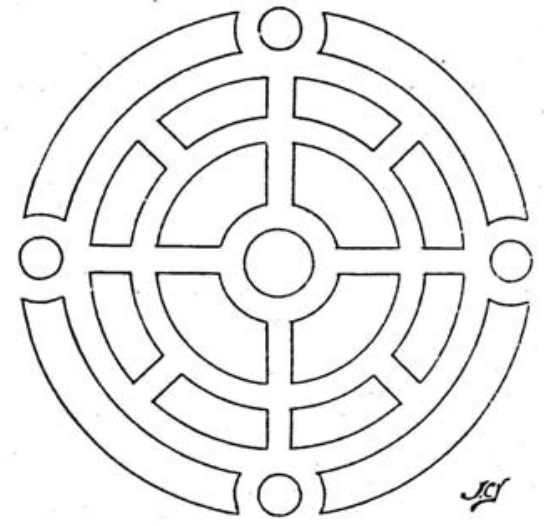

Rose garden design by J ames Young, c. 1930, which influenced the design of the Lady Norwood Rose Garden [Source: Shepherd and Cook, p. 319].

\section{Assessment of significance/heritage values}

\section{Architectural/Design:}

The Lady Norwood Rose Garden is an example of an Italian geometric garden, with a circular geometric design. It is one of New Zealand's finest rose gardens. The Lady Norwood Rose Garden's design relates to formal Victorian planting and so with the Main Garden. The Lady Norwood Rose Garden is in the High Victorian Garden style. ${ }^{217}$

\footnotetext{
213 Shepherd and Cook, p. 289.

214 Shepherd and Cook, p. 289.

215 Shepherd and Cook, p. 289.

216 Shepherd and Cook, p. 318.

217 Ramsey, p. 16.
} 


\section{Sound Shell Lawn}

The Sound Shell is not recognised by the New Zealand Historic Places Trust or the Wellington City Council District Plan

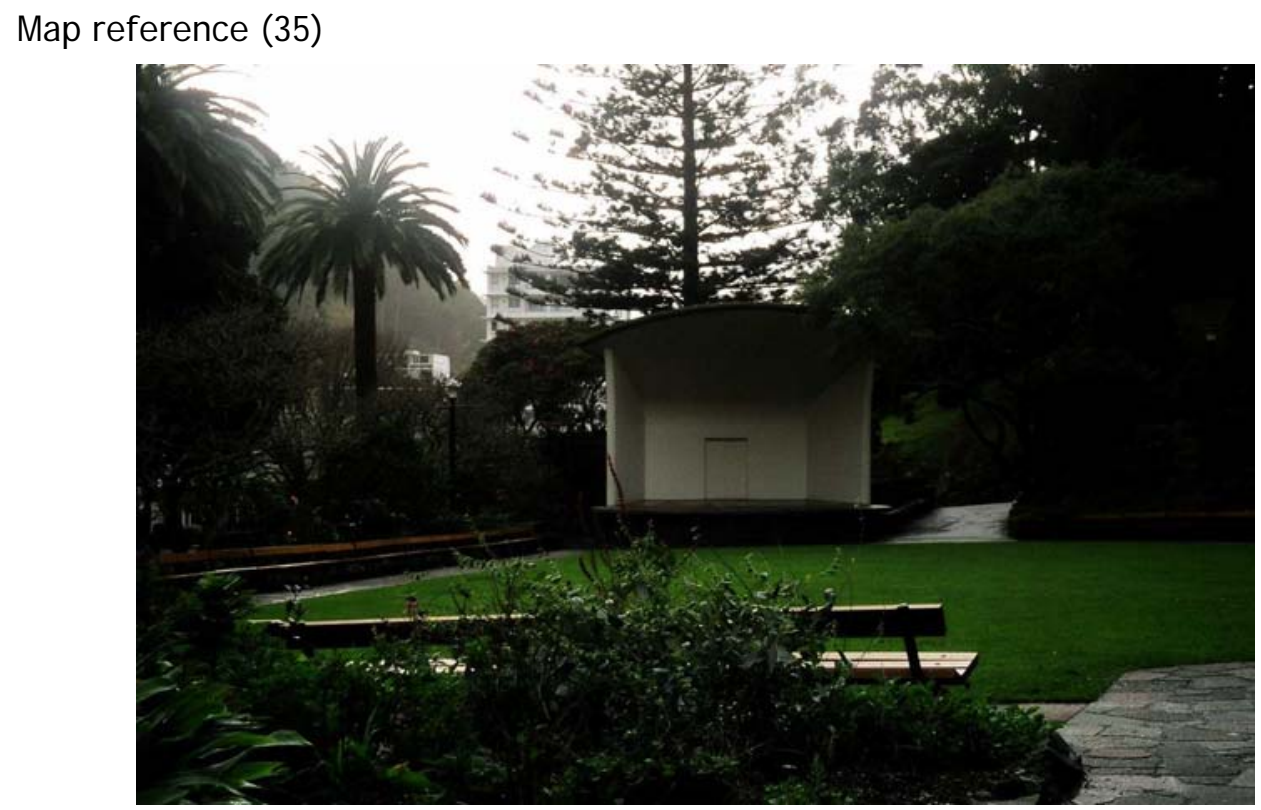

The Sound Shell and Lawn.

\section{Description:}

The Sound Shell is a reinforced concrete bandstand. ${ }^{218}$ The Sound Shell is 31 feet wide, and 19 feet deep. ${ }^{219}$

\section{Architectural Style:}

The Sound Shell was designed by R.A.E. Osten and S.E. Gurney. ${ }^{220}$ The sound shell style for bandstands was popular at this time.

\section{History:}

The area now known as the Sound Shell Lawn was originally James Hector's Teaching Garden. The Teaching Garden was established in 1886 and was a typical scientific garden with examples of each plant in boxed beds. When the City Council took over the Botanic Garden in 1891, the Teaching Garden became the Enclosed Garden. The Enclosed Garden came to feature formal bedding, and incorporated Hector's established cabbage trees and native trees. By about 1910, the Enclosed Garden was planted with roses, and the space became the Rosary. ${ }^{221}$ The roses were cleared to make way for the Sound Shell.

\footnotetext{
${ }^{218}$ Wellington City Corporation Specification and General Conditions Contract for Constructional of Sound Shell Building, Botanical Gardens, Wellington, 19 October 1951 (located in WCC File 00009:486:31/21/ 10 - Botanical Gardens-Erection of Soundshell). 219 'Mayor Opens Sound Shell for Bands in Botanical Gardens in Wellington', Dominion, 7 December 1953, no page.

220 'Sound Shell Opened by Mayor', Evening Post, 7 December 1953, no page.

${ }^{221}$ Shepherd and Cook, p. 289.
} 
Concerts at the Botanic Garden were popular from 1904, which led to the construction of a band rotunda in 1907. The rotunda remained until 1953 when the Sound Shell was erected. The Sound Shell was more versatile than the old Band Rotunda and was used for many events from December to February each year. A band played every Sunday afternoon in the Sound Shell. Popular Christmas and New Year's events were also held at the Sound Shell during the 1950s and 1960s. ${ }^{222}$

The idea of a Sound Shell in the Botanic Garden was suggested by the Wellington Bands Association as a memorial to bandsmen who had died during the Two World Wars. The Bands Association offered to finance the Sound Shell pound for pound with the City Corporation, with the hope that it would be erected in time for the Royal Visit of 1949. They also proposed a design for the building. ${ }^{223}$ The proposal was rejected by the Ministry of Works. ${ }^{224}$ However, the City Corporation was still interested in constructing the Sound Shell, so reworked the design and called for tenders in 1951. However, no tenders were offered, despite three attempts. ${ }^{225}$ Several months later two tenders were received, but were considered too high by the City Engineer, being $f 1659$ in excess of his estimate. ${ }^{226}$ Eventually, the Wellington City Council decided to go ahead with the construction of the Sound Shell by using the labour of carpenters on a cooperative basis. The cost of the Sound Shell was not to exceed $£ 4000$, with the Bands Association contributing f1200 and Council the remainder. ${ }^{227}$ By using cooperative labour, the Sound Shell came to cost $£ 3245 .{ }^{228}$

The Sound Shell was opened on 5 December 1953, with no little controversy. The Wellington Bands Association hoped to participate in the opening of the Sound Shell, and unveil a plaque to 'Wellington bandsmen who lost their lives in both World Wars'. ${ }^{229}$ However, the Council was deemed 'lackadaisical' in inviting band members to the event, and as a consequence many bands were already booked and unable to play at the opening of their Memorial Sound Shell. ${ }^{230}$ The dispute was headline news (I was able to find twelve articles about the opening). However, the opening of the Sound Shell was still attended by a good-sized crowd. ${ }^{231}$ The Sound Shell was used during the Royal Visit of early 1954. Its popularity continued with an open-air dance which attracted 8000 people in J anuary 1954. Musical expert, Lt. Col. F. Vivian Dunn, commented that the Sound Shell 'and natural amphitheatre in front of it are assets with tremendous potentialities' ${ }^{232}$

The Sound Shell is still used for Summer in the City performances.

\footnotetext{
222 Shepherd and Cook, pp. 245, 248-9.

${ }^{223}$ Letter to the District Building Controller from Acting City Engineer, 8 September 1948 (located in WCC File 00009:486:31/21/ 10 - Botanical Gardens-Erection of Soundshell). 224 Letter from S.W.P. J ones, District Building Controller to City Engineer, 29 September 1948 (located in WCC File 00009:486:31/21/ 10 - Botanical Gardens-Erection of Soundshell). 225 Memo for City Engineer from the Town Clerk, 10 December 1951 (located in WCC File 00009:486: 31/ 21/ 10 - Botanical Gardens-Erection of Soundshell).

226 Memo for the Town Clerk from the City Engineer, 17 April 1952(located in WCC File 00009:486: 31/ 21/ 10 - Botanical Gardens-Erection of Soundshell).

227 'Sound Shell to be built in Gardens', Dominion, 12 March 1953, p. 9.

228 'Mayor Opens Sound Shell for Bands in Botanical Gardens in Wellington', Dominion, 7

December 1953, no page.

229 Tritenbach, p. 76.

230 'Soundshell blacklisted?', Evening Post, 4 December 1953, no page.

231 'Sound Shell Opened', Dominion, 7 December 1953, no page.

${ }^{232}$ Concerts, Open-Air Dancing? Gardens Soundshell Should Be Big Asset', Evening Post, 19

J anuary 1954, no page.
} 


\section{Level of authenticity:}

The Sound Shell and the surrounding Lawn appear to be unchanged from the 1950s, except for the addition of the sculpture on the far lawn.

Assessment of significance/heritage values:

Historical:

The Sound Shell is dedicated to the bandsmen who have died in the two World Wars of last century.

The Sound Shell has been used for entertainment in the Botanic Garden since 1954, and is still used for its original purpose.

\section{Architectural:}

The Sound Shell is typical of other shells built at the time (such as the shell on Marine Parade, Napier).

\section{Technological:}

The Sound Shell is a natural amphitheatre and has excellent acoustic properties. 


\section{Magpie Lawn}

The Magpie Lawn is not recognised by the New Zealand Historic Places Trust or the Wellington City Council District Plan

Map reference (36)

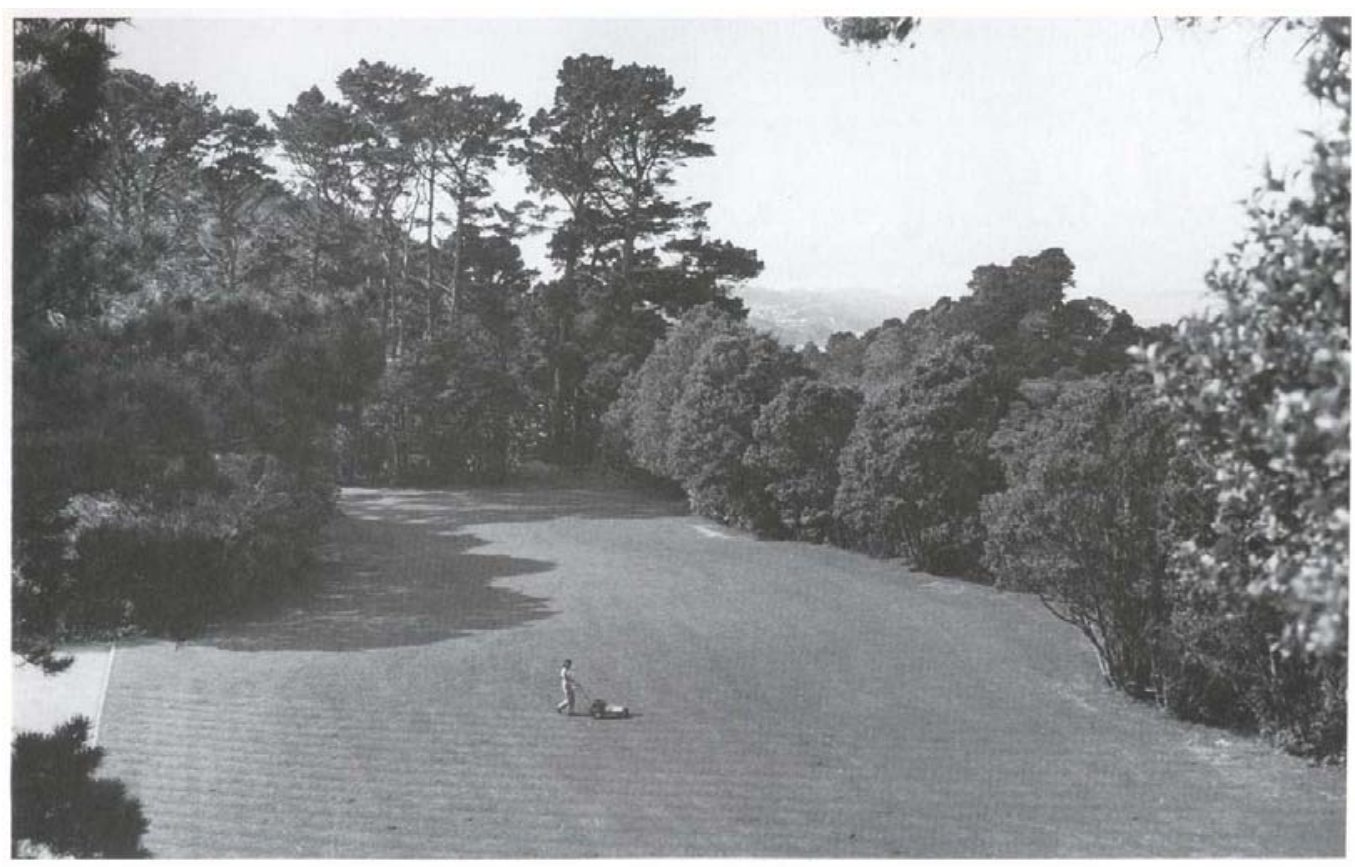

The Magpie Lawn, 1985 [Source: Shepherd and Cook, p. 247].

\section{Description:}

Magpie Lawn is a flat expanse of lawn in the south-west end of the Botanic Garden.

\section{History:}

The Magpie Lawn was the second large-scale earth works in the Botanic Garden, after the formation of Anderson Park (please see entry on Anderson Park). The Magpie Lawn used to be Magpie Hill, where some of the earliest planting in the Garden took place. However, in 1927 the pines were felled and the ridge was cut out. Again relief labour was used. ${ }^{233}$ The spoil was used to fill the Glenmore Gully (which became Glenmore Lawn, another part of the Botanic Garden). The space was flattened out in 1930, but nothing was decided upon for its use. The Magpie Lawn was used as a vegetable garden during the Second World War when the Director of the Botanic Garden, J.G. MacKenzie, gave demonstrations on how to grow vegetables as part of the 'Dig for Victory Campaign'. Today it remains as it did in 1930: an expanse of lawn for public use. ${ }^{234}$ It was popular for picnics, and organised games such as football were frowned upon for fear that it could damage the surrounding shrubbery and gardens. ${ }^{235}$

233 Letter from E. Hutt to Town Clerk, 30 May 1952, Re: Kelburn Normal School PTA, (located in WCC File 00001:1042:31/ 290/ 2 - Reserve: Botanical Gardens Magpie Lawn). ${ }^{234}$ Shepherd and Cook, pp. 154, 246, 309.

235 Letter from E. Hutt to Town Clerk, 30 September 1955, (located in WCC File 00001:1042:31/290/ 2 - Reserve: Botanical Gardens Magpie Lawn). 


\section{Level of authenticity:}

Magpie Lawn appears unchanged, and is still used public space.

Assessment of significance/heritage values:

\section{Historical}

The Magpie Lawn has been a popular picnic and children's play spot since the 1930s. It is connected to the history of the Botanic Garden and the Second World War through its role in the 'Dig for Victory' campaign. 


\section{Duck Pond}

The Duck Pond is not recognised by the New Zealand Historic Places Trust or the Wellington City Council District Plan

Map reference (37)

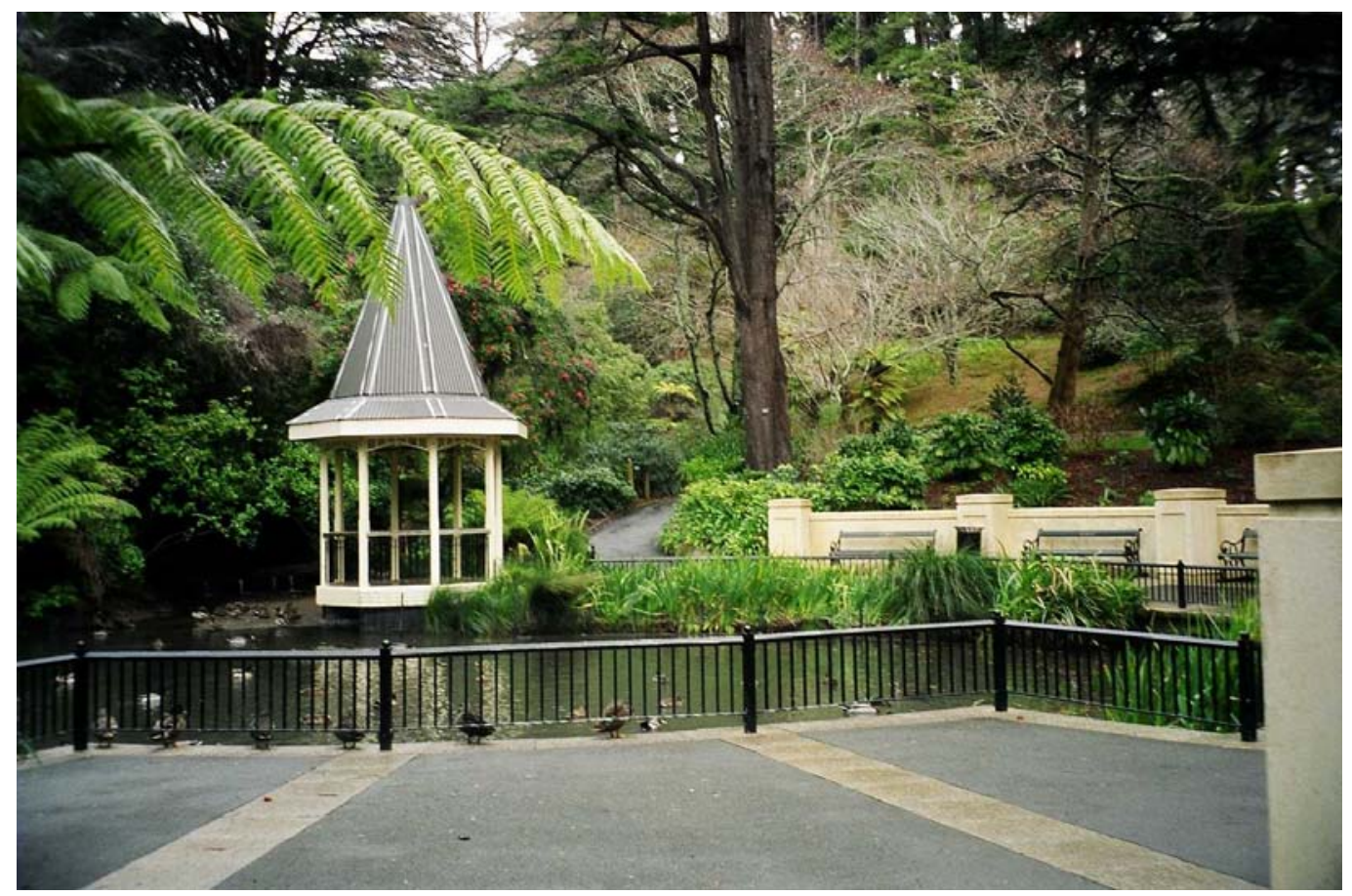

The Duck Pond and Pavilion.

\section{Description:}

The Duck Pond has been a popular spot in the Botanic Garden since 1868. It has recently been redeveloped and a pavilion added.

\section{History:}

The Duck Pond has gone through many name changes over the years. It was originally known as the Frog Pond. Then it became the Lily Pond. By 1928 it was known as the Swan Pond and it is now known as the Duck Pond. ${ }^{236}$

The Pond was already formed when the Main Path of 1874 was completed. Two bridges came off the Main Path and crossed over the Pipitea Stream before coming to the Pond, which was a natural junction of the Pipitea and Pukatea Streams. The Duck Pond is natural, although it has been improved over the years. Many of the trees around the Duck Pond are old, and were planted by William Bramley and Alfred Ludlam (such as the lime trees from 1871). ${ }^{237}$

The Duck Pond was remodelled in 1996 after a public design competition, and a Victorian-style pavilion built. The design for the Duck Pond relates to various features that are part of the Main Garden.

${ }^{236}$ Shepherd, unpublished source, p. 68.

237 Shepherd and Cook, pp. 137, 153, 156. 


\section{Modification:}

The Duck Pond was recently redeveloped, and a Victorian styled pavilion added. The pond itself has been improved in the past.

\section{Assessment of significance/heritage values:}

\section{Historical:}

The Duck Pond has been a popular spot at the Botanic Gardens since 1868, and is frequented by visitors of the Botanic Garden. It is surrounded by historic trees, which date back to the 1870s and William Bramley's time as Keeper.

\section{Architectural:}

The new Duck Pond pavilion relates to the Victorian feel of the Main Garden. The pavilion captures the formality of Victorian garden architecture, while the wrought iron relates to the Edwardian period. The soft sandstone colouring of the ' $J$ oy' $^{\prime}$ Fountain can also be seen in the paths and walkways around the Duck Pond. ${ }^{238}$

${ }^{238}$ Wellington City Council, p. 43. 


\section{Buildings that are closely associated with the Botanic Garden}

\section{Observatory Precinct:}

Sec 1231, Town of Wellington, SO 25200, (0.5936 ha), Local Purpose Reserve (Community and Administrative Buildings), Gazette 1998, page 68

Sec 1223, Town of Wellington, SO 252000 (1.5783 ha), Local Purpose Reserve (Community and Administrative Buildings), Gazette 1998, page 68

Map reference (38)

\section{Wellington's First Observatory:}

The Colonial Observatory was originally in Wellington city but was moved to a hilltop in Botanic Gardens near the Bolton Street Cemetery. The earliest government observatory was for time-keeping, and was on the waterfront near the Customs House. ${ }^{239}$ It was a 'small nondescript building' which housed two clocks and a transit telescope used for time-keeping purposes. The time ball dropped at noon to tell locals the time. Hector was an observer, as was Archdeacon Stock who carried out most of the observations. It was moved in 1906 to make way for Prime Minister Seddon's memorial. ${ }^{240}$

\section{Gardens Battery:}

The Botanic Garden Battery was one of a number constructed around Wellington during the 'Russian Scare' of 1884-6. The batteries were a series of forts erected around Wellington to defend the city from the Russian navy. ${ }^{241}$ The magazine held a seven inch RMC gun. The gun emplacement and powder magazine were constructed in 1894, and the gun secured the same year. However, the gun was never mounted. 242 The Battery consisted of a gun

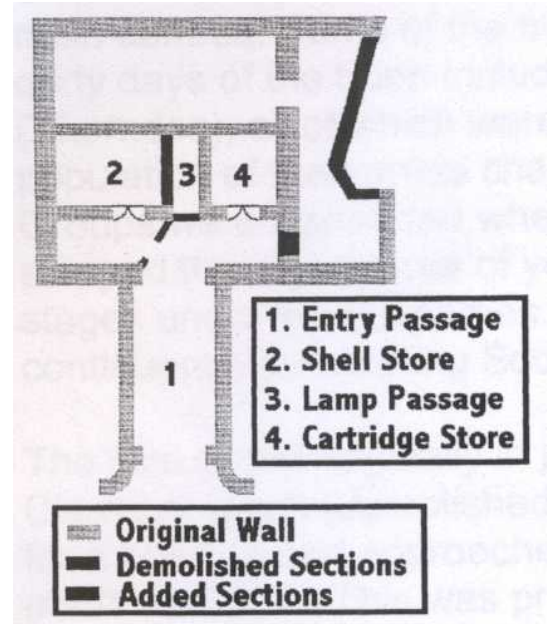

Plan of the Botanic Garden Battery [Source: Campbell Pope Architect, p. 5]. emplacement, barbette pit, observation post, loading gallery and magazine. ${ }^{243}$ By 1904 , the gun was obsolete and the Gardens Battery was demolished, leaving only the old powder magazine. ${ }^{244}$

${ }^{239}$ Dr. Wayne Orchiston, 'The Wellington Botanic Garden and Its Historical Astronomical Observatories' (Wellington: Historic Places Trust?, 1995), pp. 1-2 (located in WCC File 00277: 325: 28/ 6/ 56-Historic Places: Glenmore Street: Botanical Gardens, Gazebo and Environs).

240 Wayne Orchiston, Carter Observatory: The National Observatory of New Zealand, Information Sheet 5 'The Historic Astronomical Observatories in the Wellington Botanic Garden: A Brief Introduction' (Wellington: Carter Observatory, September 1995), pp. 1-2. ${ }^{241} \mathrm{~J}$ ames McKenzie, Dominion Observatory Precinct, Historic Places Trust Report (Wellington: Historic Places Trust, 1995), p. 3 (located in WCC File 00277:325:28/ 6/ 56Historic Places: Glenmore Street: Botanical Gardens, Gazebo and Environs).

242 Richard Nester and Chris Cochran, Dominion Observatory and Gardens Battery Conservation Plan, including a specification for remedial work and regular maintenance (Wellington: Department of Conservation, 2003), p. 9.

243 Nester and Cochran, p. 11. 


\section{Assessment of heritage values/significance:}

The Gardens Battery is a site that 'demonstrates New Zealand's early attempts to counteract threats from foreign shores'. The gun commander's residence (now the Lawson Scout Hall), the observation post and magazines still exist and are easily accessible. ${ }^{245}$

Archaeological Significance:

The site may also have archaeological significance, and Nester and Cochran recommend an archaeological excavation in order to discover the 'nature, extent and technical design of the Botanic Garden Battery' . ${ }^{246}$

\section{Climatological enclosure:}

This site was established on this site in 1928, and continuous records of rainfall, air temperature, wind speed and so on have been kept ever since. ${ }^{247}$

\section{Other features:}

Bunker:

Noted in Nester and Cochran's Dominion Observatory and Gardens Battery Conservation Plan. Described as a concrete bunker with steps leading down to it in front of the Dominion Observatory. Its flat roof is visible from above. ${ }^{248}$

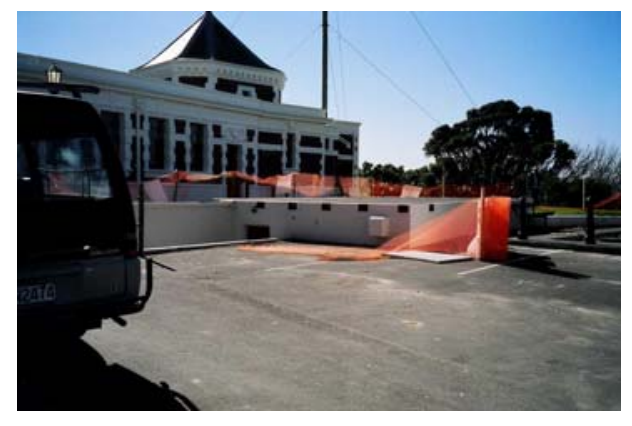

The visible remains of the Botanic Garden Battery.

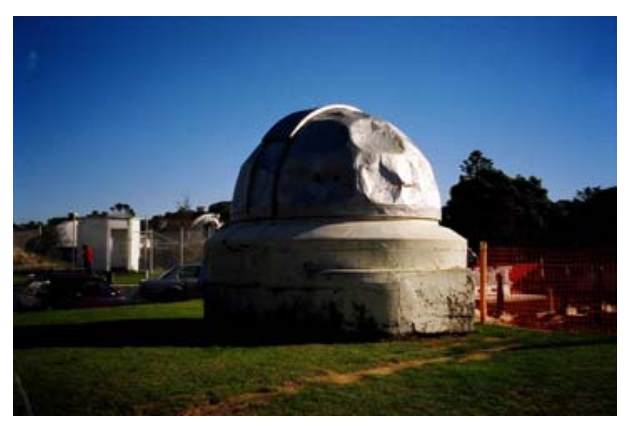

The Astrolabe at Observatory Precinct.

Astrolabe:

In damaged condition. Noted by Nester and Cochran. ${ }^{249}$

Mast:

Also noted by Nester and Cochran. The mast holds a wind speed measuring device. It stands on or near the position of the original mast, which relayed time signals for shipping. ${ }^{250}$

\footnotetext{
244 McKenzie, p. 3.

245 Nester and Cochran, p. 21.

246 Nester and Cochran, p. 22.

247 Nester and Cochran, p. 25.

248 Nester and Cochran, p. 25.

249 Nester and Cochran, p. 25.

250 Nester and Cochran, p. 25.
} 


\section{Dominion Observatory}

Originally called the Hector Observatory.

NZHPT Category I

District Plan Map 17, Reference 269

Map reference (39)

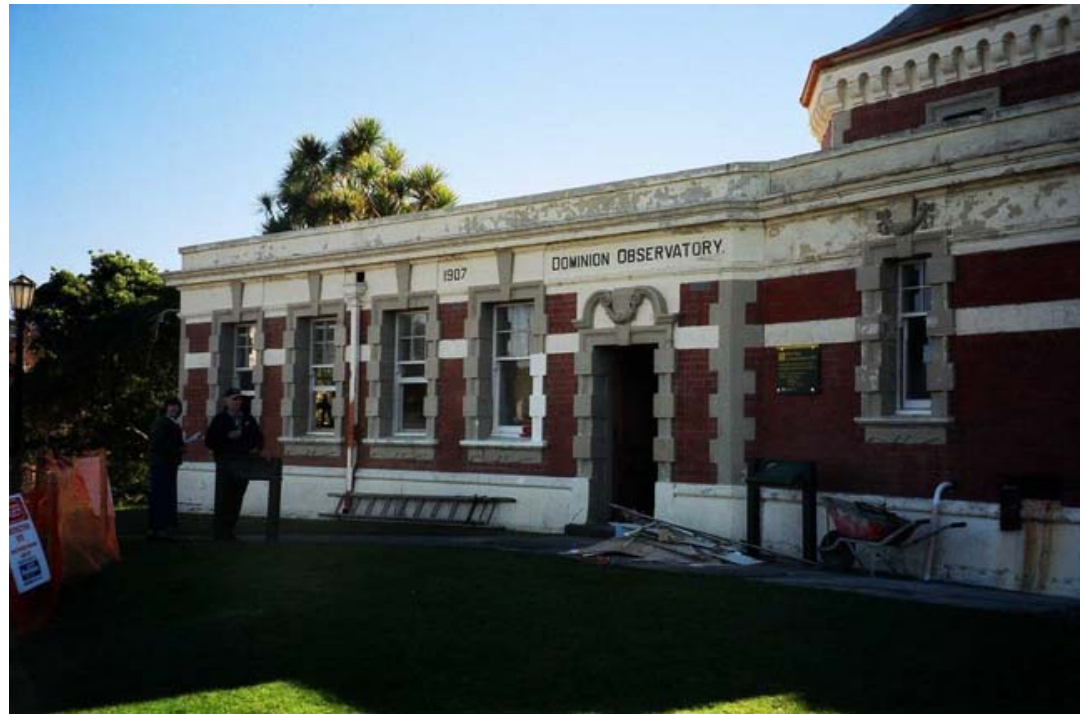

The Dominion Observatory, front.

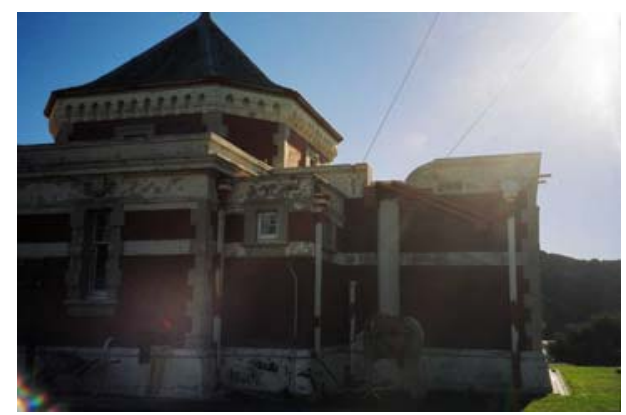

The Dominion Observatory, showing dome.

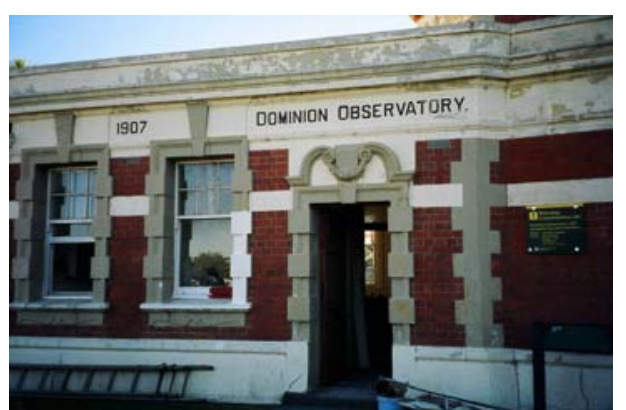

The Dominion Observatory, showing door and windows.

\section{Description:}

The Dominion Observatory consists of a transit room, an octagonal clock room and four offices on the second floor. ${ }^{251}$ There is also a basement, which was built in 1894 as part of the Gardens Battery and magazine. The building is constructed of cavity brick walls with plastered concrete on concrete foundations. The windows are double hung, with Gibb's surround ('alternating square bands with the appearance of intermittent quoins'). The quoins are limestone, possibly Oamaru stone. The parapet is concrete. The façade is red brick and plaster. The roof is slate with lead flashings. There are also Classical motifs, such as wreathes of foliage around the building. ${ }^{252}$

\footnotetext{
251 McKenzie, p. 2.

252 Nester and Cochran, pp. 7, 12, 23.
} 


\section{Architectural Style:}

J ohn Campbell was the architect of the Dominion Observatory. The Observatory is an example of Edwardian Baroque architecture, elements of which can be seen in the brickwork, plastering and quoin windows. ${ }^{253}$

\section{History:}

The Hector Observatory was built for the New Zealand Time Service in 1907, after their previous building had to be vacated to make way for the Seddon memorial. ${ }^{254}$

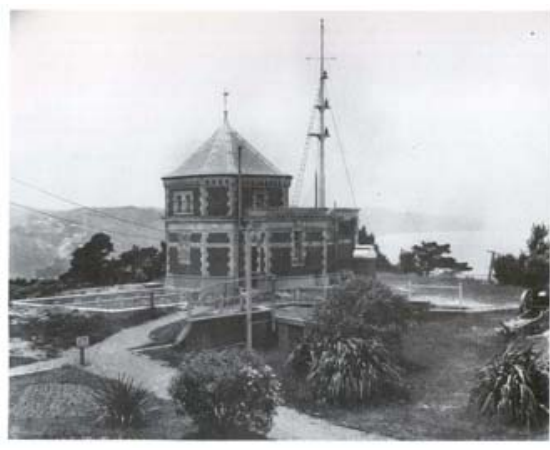

The Dominion Observatory, c. 1926 [Source: Shepherd and Cook, p. 333]. The original building was octagonal, but was later added to in the 1920s and 1930s. The Observatory was known as the Hector Observatory at the time of its construction, but it was renamed the Dominion Observatory in 1925. It was officially known from 1945 to 1995 as the Seismological Observatory. ${ }^{255}$ In 1911, Charles Edwin Adams became first Government Astronomer, and oversaw the Hector Observatory. ${ }^{256} \mathrm{He}$ worked at the Observatory until 1936, developing the science of seismology in New Zealand. Robert Hayes, also to become pre-eminent in the field of seismology, began as a cadet at the Observatory in 1920. Hayes went on to implement the Richter system in New Zealand. ${ }^{257}$ The Dominion Observatory became almost exclusively concerned with seismology after 1940, as the Carter Observatory took over. ${ }^{258}$

The Dominion Observatory has recently had a $\$ 25,000$ refurbishment and will be reopened to the public. ${ }^{259}$

\section{Modification:}

In 1926 an extension of a single storey to west of building provided room for four offices. ${ }^{260}$ Some of the interior walls are original painted brick, while others have been altered. ${ }^{261}$ During 1930s and 1950s, some minor modifications were made, for example, partitioning and subdividing of spaces within the Observatory. ${ }^{262}$

According to WCC Heritage Building Inventory, it is in authentic and relatively unaltered condition. ${ }^{263}$

\footnotetext{
253 Boffa Miskell, p. SALA3.

${ }^{254}$ www. wCc. govt. nz/ wellington/ heritage/ inventory/ pg386. html.

255 Nester and Cochran, p. 9.

256 Orchiston, p. 3.

257 Nester and Cochran, pp. 21, 22.

258 McKenzie, p. 2.

259 'Time Keeper', Cook Strait News, 11 August 2003, p. 4.

260 Nester and Cochran, p. 12.

261 Nester and Cochran, p. 13.

262 Nester and Cochran, pp. 17-18.

263 Boffa Miskell, p. SALA3.
} 


\section{Assessment of significance/heritage values:}

\section{Historical:}

According to the Boffa Miskell Wellington City Council Heritage Building Inventory, the Dominion Observatory is an important building because of its links to the history of science and astronomy in New Zealand. The building is associated with eminent scientists, such as J ames Hector and Ernest Rutherford (whose name cane be found in the visitors book). ${ }^{264}$ Scientists in areas as diverse as astronomy, seismology and physics have been associated with the Dominion Observatory. The Observatory itself was initially named after Dr. J ames Hector, said to be the father of scientific research in New Zealand. 265

The Dominion Observatory was New Zealand's primary site for developing and recording New Zealand Standard Time. According to Nester and Cochran, '[s]uch recording gave rise to New Zealand's own identity in spatial time and place relative to the rest of the world. This helped improve nation-wide surveying and navigation ability'. They go on to say that the 'building was part of a global network of time keeping observatories, therefore giving this building high values in both national and international significance'. The Dominion Observatory was used for seismological research and recording. ${ }^{266}$

\section{Architectural:}

According to the Wellington City Council Heritage Building Inventory 2001, the Observatory has aesthetic value as 'a confined and competent example of Edwardian Baroque architecture by the Government architect of the day' J ohn Campbell. ${ }^{267}$

According to Wellington City Council, the Dominion Observatory is a good example of the 'smaller type of building designed for a specific purpose by the Government Architect'. 268

John Campbell was born in Glasgow, and arrived in New Zealand in 1882 . He worked in Dunedin for the Public Works Department, and moved to Wellington in 1888. He was made Government Architect in 1890, and remained in the office until his retirement in 1920. Some of his early work was in the Queen Anne style (for example the Dunedin Police Station) but by about 1903 he had established Edwardian Baroque as the style for New Zealand public buildings. Campbell's other buildings include the Public Trust Building (1905), and Parliament Buildings (1910). ${ }^{269}$

\section{Technological:}

According to Nester and Cochran's study, there are various areas of technical interest, these being: the mass concrete construction in battery and basement; the

\footnotetext{
264 Boffa Miskell, p. SALA3.

265 Nester and Cochran, p. 21.

${ }^{266}$ Nester and Cochran, p. 21.

${ }^{267}$ Boffa Miskell, p. SALA3.

${ }^{268}$ Tom Niven, Wellington City Council Proposed Changes to the Operative District Plan, 1987 (located in WCC File 00057:5:87/ 11- Reclassification of Dominion Observatory, Salamanca Rd, Kelburn).

${ }^{269}$ Nester and Cochran, p. 23.
} 
cavity brick construction of the Observatory; the limestone quoins; the timber roof framing; the roof slating and lead-work and the turret roof; and the decorative plaster work. Nester and Cochran believe that information about the 'construction and source of materials, their detailing and use, and their degradation over time' would be useful. ${ }^{270}$

There is also technical significance related to the building's use as an observatory, such as the roof opening mechanism and the plinths for mounting instruments. ${ }^{271}$

\section{Aesthetic:}

The Dominion Observatory has landscape significance because of its commanding view of Wellington. The building is also closely associated with the Botanic Gardens, the Dominion Observatory Precinct and the Cable Car. ${ }^{272}$

${ }^{270}$ Nester and Cochran, pp. 23-4.

${ }^{271}$ Nester and Cochran, p. 24.

272 Nester and Cochran, p. 24. 


\section{Thomas King Observatory}

Also known as the King Edward VII Memorial Observatory and Observatory of the Astronomical Section.

The Thomas King Observatory is not recognised by the New Zealand Historic Places Trust or the Wellington City Council District Plan

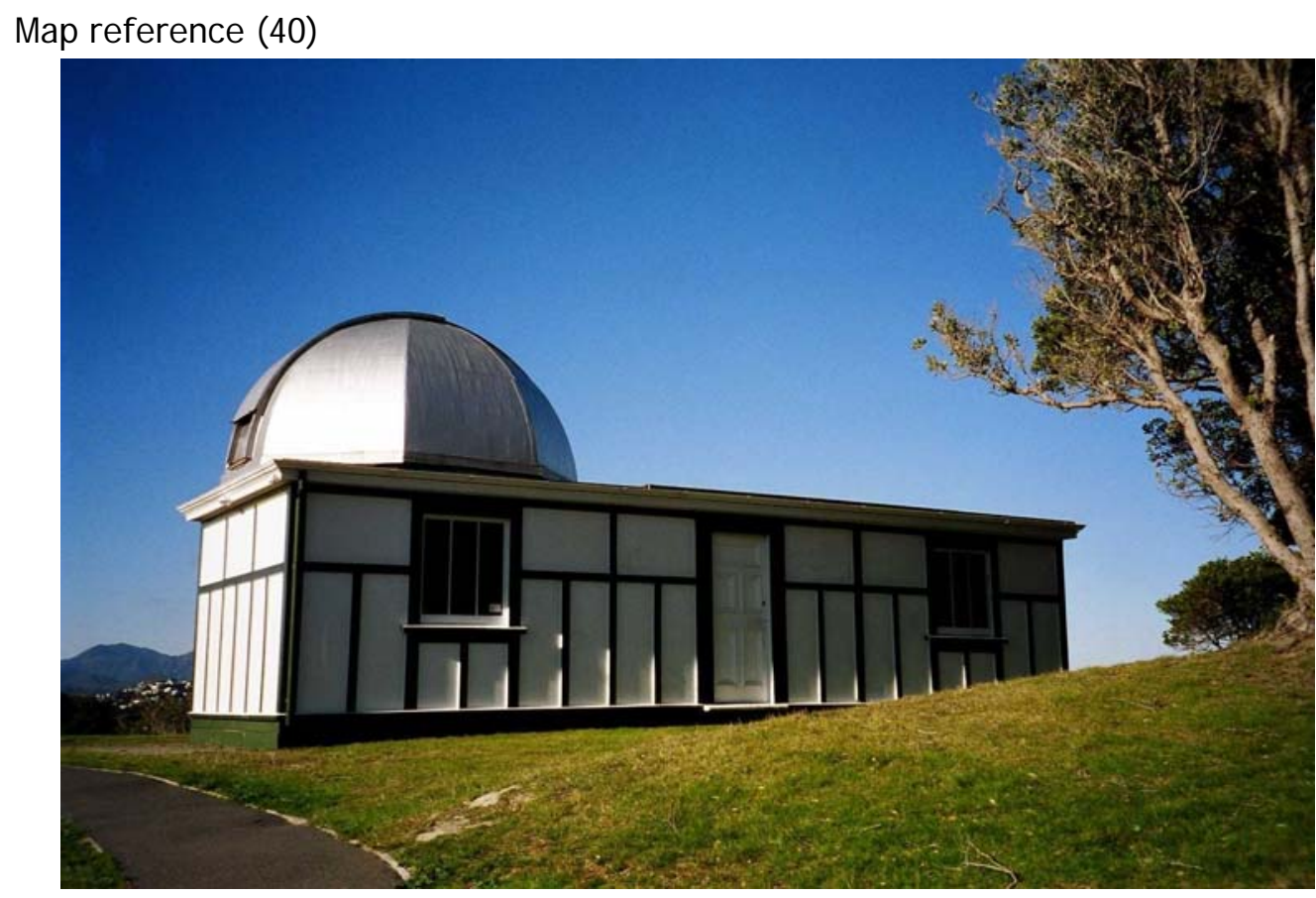

The Thomas King Observatory.

\section{Description:}

The Thomas King Observatory is constructed of timber framing sheathed in asbestos. The dome is timber with ruberoid (butyl rubber with bitumous aluminium) paint for waterproofing. ${ }^{273}$

\section{Architectural Style:}

Built by McLean and Gray builders. The Thomas King Observatory is a simple wooden building constructed for utility.

\section{History:}

The King Edward VII Memorial Observatory was erected in 1912 by the Astronomical Section of the Wellington Philosophical Society. The Society felt that there was a need for a public observatory, as astronomy was a popular pastime during the late $19^{\text {th }}$ and early $20^{\text {th }}$ centuries because of the Transit of Venus in 1874 and 1882 and

${ }^{273} \mathrm{~J}$.B. Seymour, A History of the Thomas King Observatory of Wellington unpublished article?, no date, p. 4; Works Consultancy Services Ltd, Thomas King Observatory, Kelburn, Building Assessment for Wellington City Council, c. 1994-5, p. 3. 
other astronomical occurrences. ${ }^{274}$ The Society hoped to gain funds from the New Zealand Institute but had no luck. They were also unable to gain access to the Carter bequest, so instead turned to private fundraising. ${ }^{275}$ The site chosen, centrally located on a hill overlooking the Hector/ Dominion Observatory, was part of the Garden Battery Reserve, so permission had to be sought from the Ministry of Lands. ${ }^{276}$ The land was reclassified in 1913. ${ }^{277}$

The building was originally called the King Edward VII Memorial Observatory, but the name did not prove popular. It was then known as the Observatory of the Astronomical Section. ${ }^{278}$ However, by the Second World War, it became known as the Thomas King Observatory. ${ }^{279}$ Thomas King was born in Glasgow, but immigrated to New Zealand. In 1887 he took over the full-time position of Transit Observer at the Colonial Observatory. He held this position until 1911, and died in 1916. He was an active member of the Wellington Philosophical Society, and his Grubb telescope was donated to the Society on his death. ${ }^{280}$ The Observatory was used for public evenings during the 1920s. In the 1970s, there was a renewed interest in astronomy, and the Thomas King Observatory was repaired and used by amateur astronomers. ${ }^{281}$ However, by the 1980s, it was again in poor condition and the Observatory has been little used in recent times, having suffered from vandalism. The telescope was removed in 1992 because of vandalism. However, the Observatory is now restored. ${ }^{282}$

\section{Modification:}

The Thomas King Observatory has suffered from years of neglect, and has been rescued and restored a number of times. The latest restoration was in 1996.

\section{Assessment of significance/heritage values:}

\section{Historical:}

The Thomas King Observatory is 'of real interest in the history of New Zealand astronomy' according to J ohn Seymour from the Carter Observatory. The Thomas King Observatory has been used by some of the 'country's most eminent astronomers' for research. ${ }^{283}$

The Thomas King Observatory was formerly New Zealand's leading astronomical research facility. It is closely associated with both professional and amateur astronomers.

\footnotetext{
${ }^{274}$ J.B. Seymour, p. 1.

275 J ohn Seymour, 'Carter Observatory: The National Observatory of New Zealand, Information Sheet 9 'A History of the Thomas King Observatory' 'February 1997), pp. 1-3.

${ }^{276}$ Seymour, 'Carter Observatory: The National Observatory of New Zealand, Information Sheet 9 'A History of the Thomas King Observatory' ' p. 3.

277 Seymour, History of the Thomas King Observatory of Wellington, p. 4.

278 Seymour, 'Carter Observatory: The National Observatory of New Zealand, Information Sheet 9 'A History of the Thomas King Observatory', p. 3.

279 Orchiston, p. 4.

${ }^{280}$ Seymour, 'Carter Observatory: The National Observatory of New Zealand, Information Sheet 9 'A History of the Thomas King Observatory', p. 4.

${ }^{281}$ Seymour, 'Carter Observatory: The National Observatory of New Zealand, Information Sheet 9 'A History of the Thomas King Observatory', p. 5.

282 Seymour, 'Carter Observatory: The National Observatory of New Zealand, Information Sheet 9 'A History of the Thomas King Observatory', p. 6.

${ }^{283} \mathrm{~J}$. B. Seymour, History of the Thomas King Observatory of Wellington, p. 5.
} 
The Thomas King Observatory is part of the Observatory Precinct, which charts the history of New Zealand astronomy, time-keeping and seismology through the buildings which are preserved there.

\section{Social}

The Thomas King Observatory is closely linked to the Wellington Philosophical Society, and the many professional and amateur astronomers who have used the facility. 


\section{Carter Observatory}

NZHPT Classification C

District Plan: Map 17, Reference 268.

Lot 1 DP 74620 (0.2023 ha)

Map reference (41)

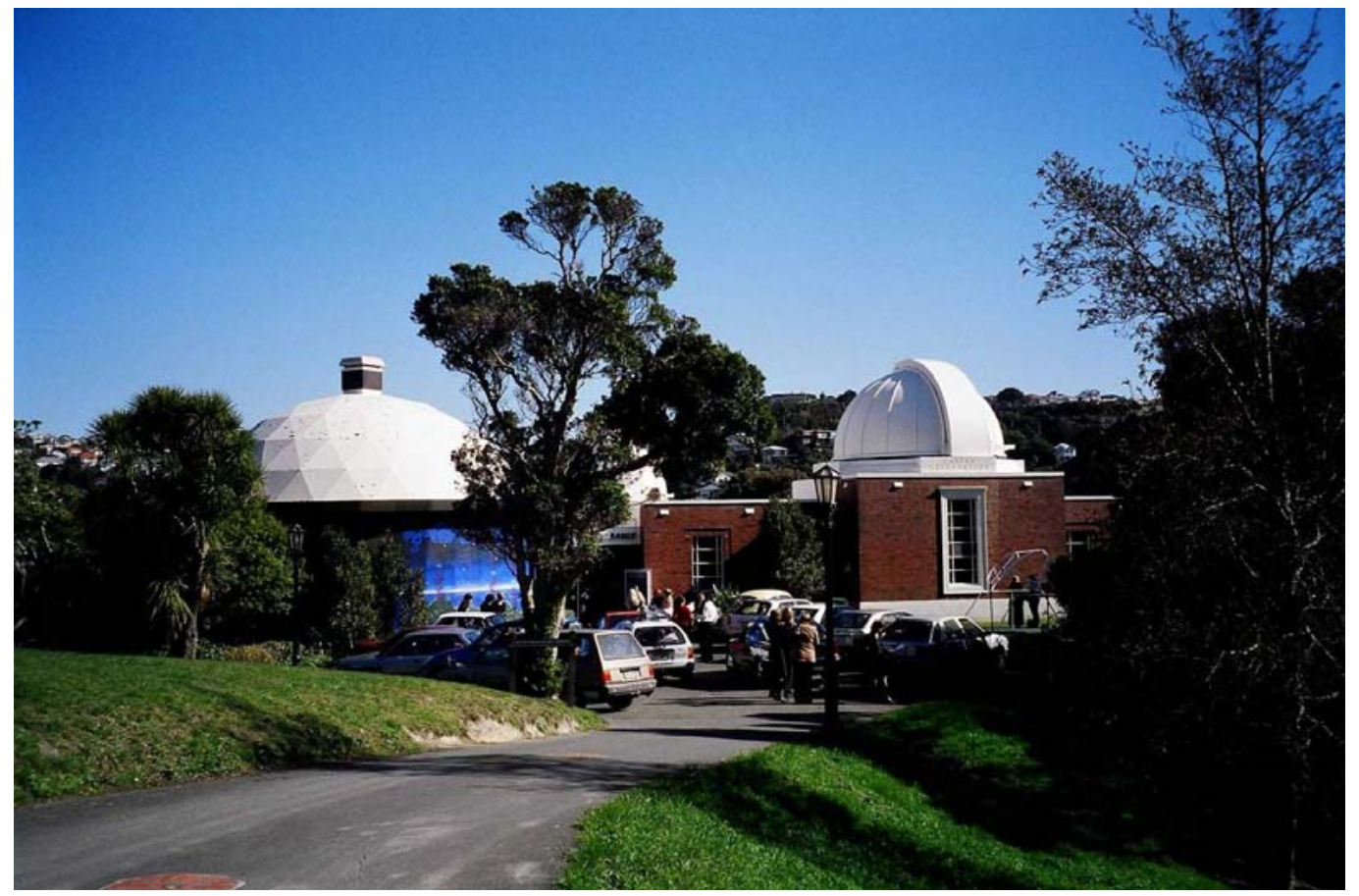

The Carter Observatory and Golden Bay Planetarium.

\section{Description:}

The Carter Observatory is the National Observatory of New Zealand. The Carter Observatory is joined by the Golden Bay Planetarium, which was formerly sited in the Civic Square in Wellington City. ${ }^{284}$ The Observatory is constructed of masonry brick on a concrete base, with reinforced steel strengthening. The joinery is wood and the observatory dome has a brick podium. ${ }^{285}$

\section{Architectural Style:}

The Carter Observatory is in the Georgian Revival style. The Carter Observatory was designed by William Gray Young, and constructed in 1940-1941. Elements of the Georgian Revival style can be seen in the 'elegant and simple brick podium, with its projecting and receding bays, [which] contrast[s] effectively with the dominant spheres of the observatory chambers. Each of these bays carries a central window, which emphasises the internal focus of the building' . ${ }^{286}$

\footnotetext{
${ }^{284}$ Kernohan, Wellington's Old Buildings, p. 228.

${ }^{285}$ Kernohan, Wellington's Old Buildings, p. 228.

${ }^{286}$ www. wcc. govt. nz/ wellington/ heritage/ inventory/ pg385. html.
} 


\section{History:}

The 'Tin Shed' was the forerunner to the Carter Observatory and was opened in 1924 by the Wellington City Corporation. It was officially known as the Wellington City Observatory, and was a 'rustic' $5.5 \mathrm{~m} \times 11 \mathrm{~m}$ building. It was made of galvanised iron, and had a flat run-off roof. It contained a $23 \mathrm{~cm}$ refracting telescope worth $f 2000$ bought in 1923 from the Marist Seminary near Napier. The 'Tin Shed' attracted many amateurs during the 1920s and 1930s. ${ }^{287}$ It occupied what is now the Carter Observatory car park, and was demolished to make way for the new observatory. ${ }^{288}$

The origins of the Carter Observatory lie with the Charles Rooking Carter bequest of 1896. In the 1930s, the New Zealand Institute, the Wellington City Council and the Royal Astronomical Society appealed to the government for an astronomical research facility, and the Carter Observatory Act was passed in 1938. The Carter Observatory was an official 'centennial' project, but the Second World War intervened and the Observatory was officially opened on 20 December 1941, with a nine-inch refractor telescope. A two-storey library was added in 1967, due to the Ruth Crisp bequest. The Crisp bequest also allowed the installation of a 16 inch Boller and Chiven refracting telescope in the Carter Observatory's second dome. In 1977, the Carter Observatory was recognised as the National Observatory of New Zealand. The Boller and Chiven telescope was replaced in 1982 by another bequeathed instrument. ${ }^{289}$

The Carter Observatory has a strong educational focus, and runs many public viewing evenings and education programmes.

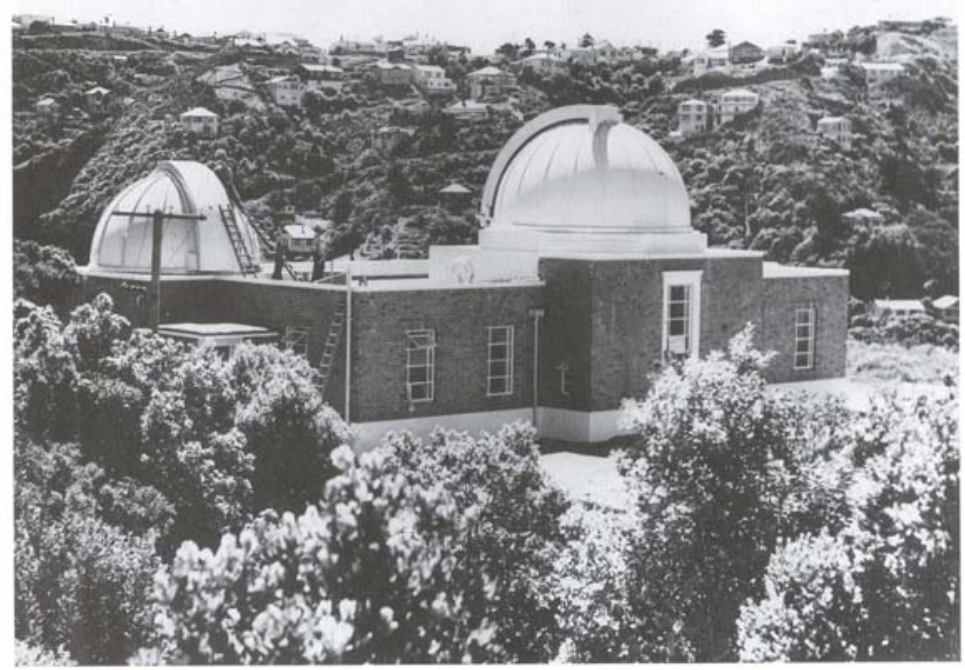

The Carter Observatory c. 1955 [Source: Shepherd and Cook, p. 342].

\footnotetext{
287 Orchiston, p. 5.

${ }^{288}$ Wayne Orchiston and Richard Dodd, 'Carter Observatory: The National Observatory of New Zealand, Information Sheet 1 'A Brief History of the Carter Observatory' (Wellington: Carter Observatory, September 1995), p. 1.

${ }^{289}$ www. wcc. govt. nz/ wellington/ heritage/ inventory/ pg385. html; Orchiston and Dodd, p. 1.
} 


\section{Level of authenticity:}

According to the Wellington City Council Heritage Inventory online, the building has a high level of authenticity in materials, setting, design and workmanship. The building retains its original use values. ${ }^{290}$

\section{Assessment of significance/heritage values:}

\section{Historical}

According to the Wellington City Council Heritage Inventory, the Carter Observatory is 'a unique and interesting building in Wellington, which has aided in educating and entertaining the public for a number of years. It has a prominent shape which has been a highly visual element in the Botanical (sic) Garden'. ${ }^{291}$

The Carter Observatory is closely related to the history of astronomy in New Zealand, and is the National Observatory. It is also closely linked to the other buildings in the Observatory Precinct.

The National Archives and National Museum do not collect astronomical information, so the Carter Observatory acts as an archive of scientific instruments, archives, memorabilia and ephemera. ${ }^{292}$

\section{Architectural}

The architect was William Gray Young, a prominent New Zealand architect who designed over 500 buildings in his long career. ${ }^{293}$ Gray Young is responsible for many buildings in Wellington, including the Railway Station, Elliot House, The Wellesley Club and the Stout, Kirk and Easterfield buildings at Victoria University of Wellington. ${ }^{294}$ Gray Young favoured the clean profiles of the Georgian Revival and disliked the Victorian gothic style of architecture. ${ }^{295}$

\footnotetext{
${ }^{290}$ www. wcc. govt. nz/ wellington/ heritage/ inventory/ pg385. html.

${ }^{291}$ www. wcc. govt. nz/ wellington/ heritage/ inventory/ pg385. html.

292 Orchiston and Dodd, pp. 7-8.

${ }^{293}$ www. wcc. govt. nz/ wellington/ heritage/ inventory/ pg385. html.

${ }^{294}$ Kernohan, Wellington's Old Buildings, p. 26.

${ }^{295}$ www. wCc. govt. nz/ wellington/ heritage/ inventory/ pg385. html.
} 


\section{Meteorological Office}

The Meteorological Office is not recognised by the New Zealand Historic Places Trust or the Wellington City Council District Plan

Section 1231 and 1223 of Town of Wellington

Map reference (42)

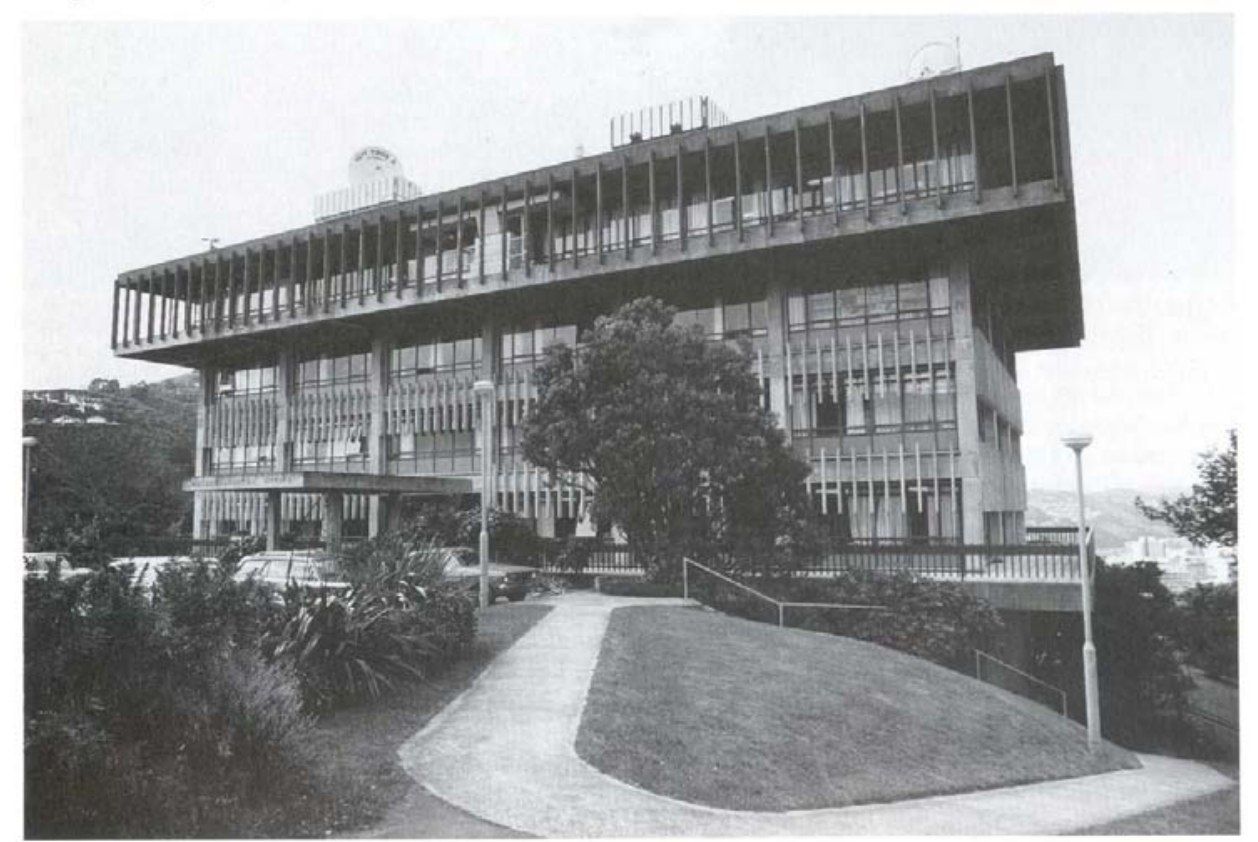

The Meteorological Office before removal of decorative fins, 1985

[Source: Shepherd and Cook, p. 346].

\section{Description:}

The Meteorological Office is a four storey, free-standing reinforced concrete structure. It was completed in 1968. ${ }^{296}$

\section{Architectural Style:}

The Meteorological Office is in the Modern style. It was designed in 1962 by the Government Architect (Ministry of Works), Fergus Sheppard and design architect Bill Alington. The contractors were Upton and Shearer Construction Limited. ${ }^{297}$

\section{Modification:}

The removal of sculptural fins has altered the character of the building.

\section{Level of authenticity:}

The Meteorological Office retains high levels of authenticity in design, craftsmanship and materials.

${ }^{296}$ Boffa Miskell, p. SALA1.

${ }^{297}$ Boffa Miskell, p. SALA1; Kernohan, Wellington's New Buildings, p. 207. 


\section{Assessment of significance/heritage values:}

\section{Historical:}

This building has been used by the New Zealand Meteorological Service since 1968, and is the national headquarters.

\section{Architectural}

The building is architecturally significant because of its innovative design and distinctive form. Careful attention to detail is apparent, and the concrete has a textured finish. The fourth floor and roof have sculptural qualities. The fourth floor is cantilevered out beyond the lower floors. Columns, beams and floor slab edges are visible. ${ }^{298}$ The concrete work is of a quality rarely seen in Wellington. ${ }^{299}$

\section{Aesthetic}

The Meteorological Office has landmark value because of position overlooking Wellington, and is described in Boffa Miskell's report as one of the 'iconic structures of the capital city'. 300

${ }^{298}$ Boffa Miskell, p. SALA1.

${ }^{299}$ Shepherd and Cook, p. 346.

${ }^{300}$ Boffa Miskell, p. SALA1. 


\section{Cable Car Winding House:}

District Plan Map 17, Reference 30.

The Cable Car Winding House is not recognised by the New Zealand Historic Places Trust

Pt Wesleyan College Reserve, Town of Wellington, SO 10408 (0.884 ha), Kelburn and Karori Tramway, Gazette 1899, page 2316

Map reference (43)

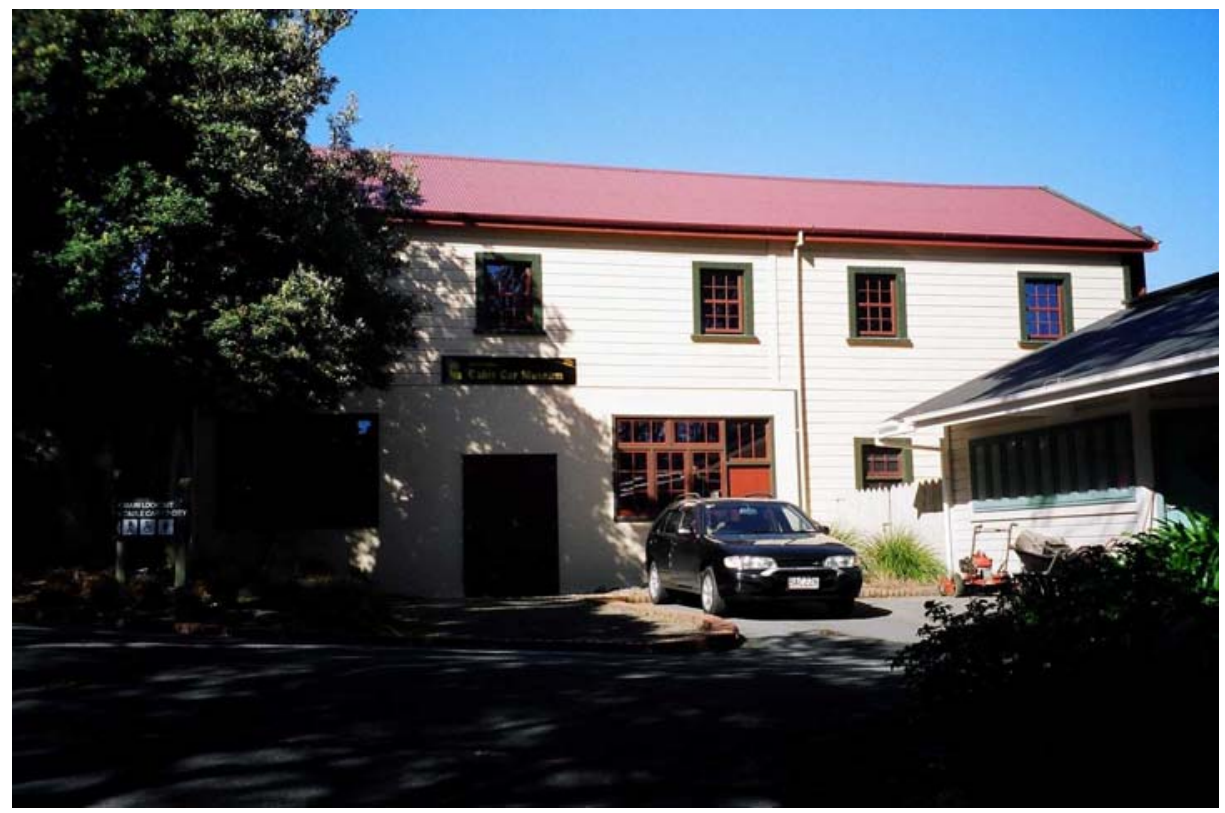

The Cable Car Winding House, rear.

\section{Description:}

The Cable Car Winding House was used as an engineering shed to house the steam engine which used to power the Kelburn-Karori tramway. The Cable Car Winding House is timber framed with weatherboard, on a concrete basement. The roof is corrugated iron. The windows are multi-paned sash windows, which add a little refinery to the utilitarian building. The interior rafters are exposed. ${ }^{301}$

\section{Architectural Style:}

The Cable Car Winding House is in the Edwardian Georgian style. The architect was J ames E. Fulton (engineer). The building was constructed 1900-1901. ${ }^{302}$

\section{History:}

The Cable Car was built by a private company, the Kelburn and Karori Tramway Company. Construction of the Cable Car began in 1899, and by 1902 the Cable Car was running. The Cable Car was immediately popular: within the first year 425,000 people rode the Cable Car. The Cable Car brought the Botanic Garden into easy

\footnotetext{
301 www. wcc.govt. nz/ wellington/ heritage/ inventory/ pg52.html.

302 www. wcc.govt.nz/ wellington/ heritage/ inventory/ pg52.html.
} 
reach of the city, and the establishment of a tea kiosk in 1904 meant that refreshments were available during visits to the Botanic Garden. The popularity of the Cable Car meant that new routes through the Botanic Garden were used by visitors, and the staff responded by opening up areas such as the Nursery for public interest. The Cable Car is the most common way of accessing the Botanic Garden, and many paths and gardens have been established over the years to welcome visitors to the Garden. ${ }^{303}$

The Cable Car Winding House was built in 1900-1901 to house the steam engine which powered the Kelburn-Karori

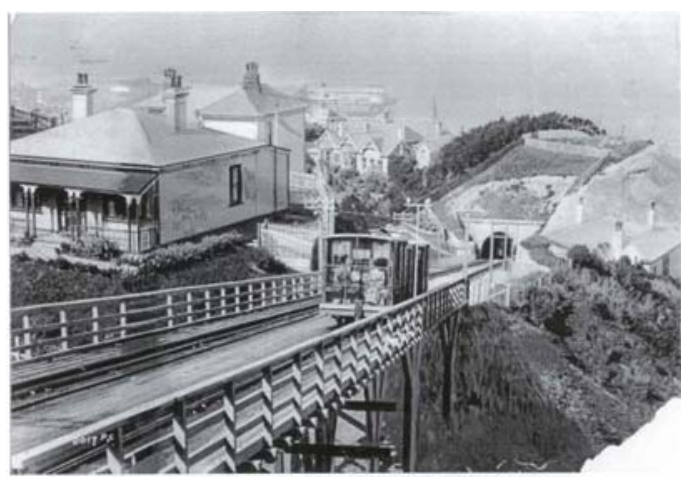

The Cable Car in c. 1902 [Source: Alexander Turnbull Library, 1/2008120]. cable car. An engineer controlled the cable car from the winding shed. The steam engine was replaced by two 120-horse power electric engines in 1933. 304

Today the Cable Car Winding House is used as a museum, and still houses some of the original winding gear.

The Cable Car Winding House has links to the Lawson Scout Hall, as the Hall was used as a residence for the custodian of the Cable Car in about 1912 (please see entry on Lawson Scout Hall).

\section{Modification:}

Presumably some modification has occurred over the years, firstly when the engines were changed from steam powered to electric. The creation of a museum has also altered the internal structure of the building. However, the exterior has retained its original character. It also retains its original functional use values.

\section{Assessment of significance/heritage values:}

\section{Historical:}

The Cable Car Winding House is an important part of the Cable Car's history, and is used to demonstrate the history of the Cable Car in Wellington.

\section{Architectural:}

The Cable Car Winding House is a good example of utilitarian architecture, in this instance an engineering shed. A few touches such as the windows add character to the building.

\section{Aesthetic}

The Cable Car Winding House has landmark value as part of one of Wellington's key tourist attractions, the Cable Car.

\footnotetext{
${ }^{303}$ Shepherd and Cook, pp. 237, 284.

${ }^{304}$ www. wcc. govt. nz/ wellington/ heritage/ inventory/ pg52. html.
} 


\section{Sexton's Cottage}

\section{Bolton St}

NZHPT Classification II (C)

District Plan Map 17, reference 375

Map reference (44)

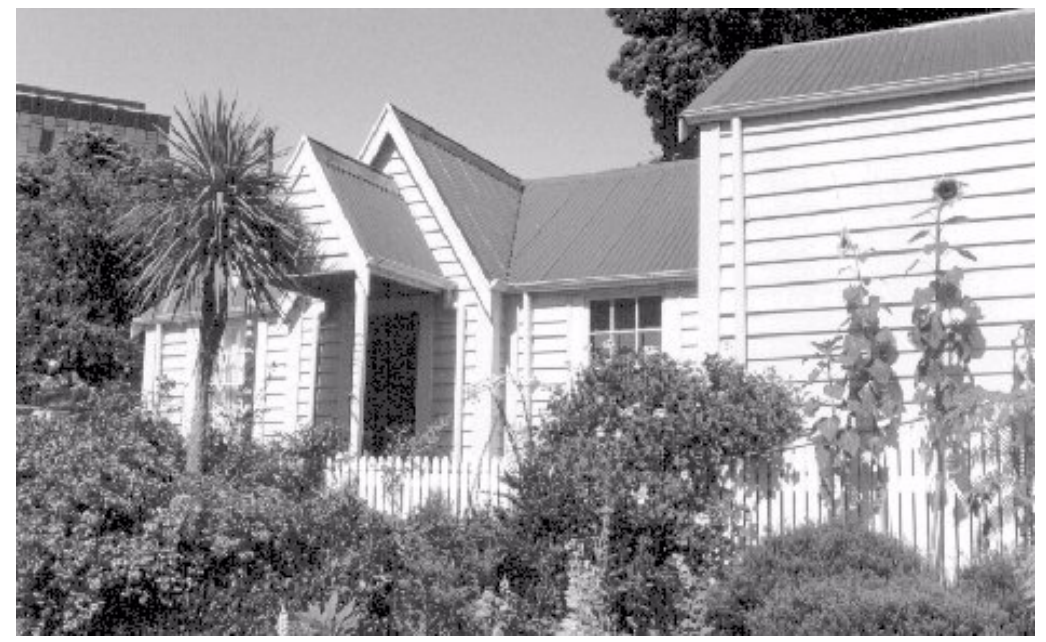

The Sexton's Cottage [Source:

http:/ / www. wcc.govt.nz/ wellington/ heritage/ inventory/ pg48. html]

\section{Description:}

The Sexton's Cottage was a residential dwelling which has now been restored and is a popular aspect of the Bolton Street Memorial Park. The cottage consists of four rooms. The cottage was built directly onto the ground without foundations. The roof was originally shingle, but it is now corrugated iron. The building is timber clad, with timber joinery. The roof is steeply pitched, and this is mirrored in the porch gable. ${ }^{305}$

\section{Architectural Style:}

The Sexton's Cottage was built in 1857 in the Victorian Georgian style. ${ }^{306}$ The architect is unknown.

\section{History:}

The Sexton's Cottage was built in 1857 for the sexton of the Church of England cemetery (please see entry on Bolton Street Memorial Park). The cottage was built by Charles Mills and the men of the $65^{\text {th }}$ Regiment. Additions were made to the cottage in 1885. Tenants occupied the cottage until 1865, when the sexton moved in. 307

\footnotetext{
305 http:/ / www. wcc. govt. nz/ wellington/ heritage/ inventory/ pg48. html 306 http:/ / www. wcc. govt. nz/ wellington/ heritage/ inventory/ pg48. html ${ }^{307}$ http:// www. wcc. govt. nz/ wellington/ heritage/ inventory/ pg48. html
} 
The cottage was sold by the Church of England in 1920, and was later bought by the Ministry of Works in 1965. The Ministry of Works restored the building, which had been condemned after the Second World War. ${ }^{308}$

\section{Modification:}

An 'unsympathetic' addition was added to the building in 1885 . However the addition has a 'rough charm in its very prosaic design'. 309 The Cottage was renovated in 1956 and 1976. The front porch was altered by the Ministry of Works in their 1976 renovations. ${ }^{310}$

\section{Level of authenticity:}

There is a high level of authenticity in design, materials and craftsmanship.

\section{Assessment of significance/heritage values:}

\section{Historical}

According to the Wellington City Council Online Heritage Inventory, the Sexton's Cottage 'is a significant and unique building type associated with the traditional customs of the Church of England'. ${ }^{311}$

\section{Architectural}

The Inventory goes on to say that the cottage is a 'significant and rare building type in Wellington, which is an important architectural and historical fixture adjoining the Bolton Street Cemetery'. ${ }^{312}$

The building is typical of early colonial structures, as it shows that working buildings were often added to.

\section{Spiritual}

The Sexton's Cottage has a strong relationship to the Church of England in Wellington, and also with the Bolton Street Cemetery where 8,000 of Wellington's early residents were buried.

NB: The Memorial Chapel at the Bolton Street Memorial Park is a replica of the original mortuary chapel that was built in 1866. The original was dismantled to make way for the new motorway but was could not be reconstructed as it was too dilapidated. ${ }^{313}$

\footnotetext{
308 http:/ / www. wcc. govt. nz/ wellington/ heritage/ inventory/ pg48. html

309 http:/ / www. wcc. govt. nz/ wellington/ heritage/ inventory/ pg48. html

310 Margaret Alington, 'Life After Death: An Old Cemetery Becomes a Memorial Park' in David Hamer and Roberta Nicholls The Making of Wellington 1800-1914 (Wellington: Victoria University Press, 1990), p. 135.

311 http:/ / www. wcc. govt. nz/ wellington/ heritage/ inventory/ pg48. html

312 http:// www. wcc. govt. nz/ wellington/ heritage/ inventory/ pg48. html

${ }^{313}$ Wellington City Council, Combined Management Plan, p. 34.
} 


\section{Spaces that are closely associated with the Botanic Garden:}

\section{Bolton Street Memorial Park}

Pt Cemetery Reserve, Town of Wellington, (0.0303 ha), Gazetted as 'Private Burial Ground of the Right Honourable Richard John Seddon and his wife and Descendants', Gazette 1923, page 2752

Lot 2 DP 50793 (1.3580 ha), Historic Purpose Reserve, Gazette 1980, page 3765

Pt Lot 1 "A", DP 8370, SO 32705 (0.3104 ha), Historic Purposes Reserve, Gazette 1989, page 3413

Pt Lot 1 "B", DP 8370, SO 32705, (0.4815 ha), Historic Purposes Reserve, Gazette 1989, page 6283

Pt Sec 473, Town of Wellington, SO 10408 A 1203, (0.0139 ha), Historic Purposes Reserve, Gazette 1989, page 3413

Sec 1, SO 36610 (0.2062 ha), Historic Purposes Reserve, Gazette 1991, page 3593

Map reference (45)

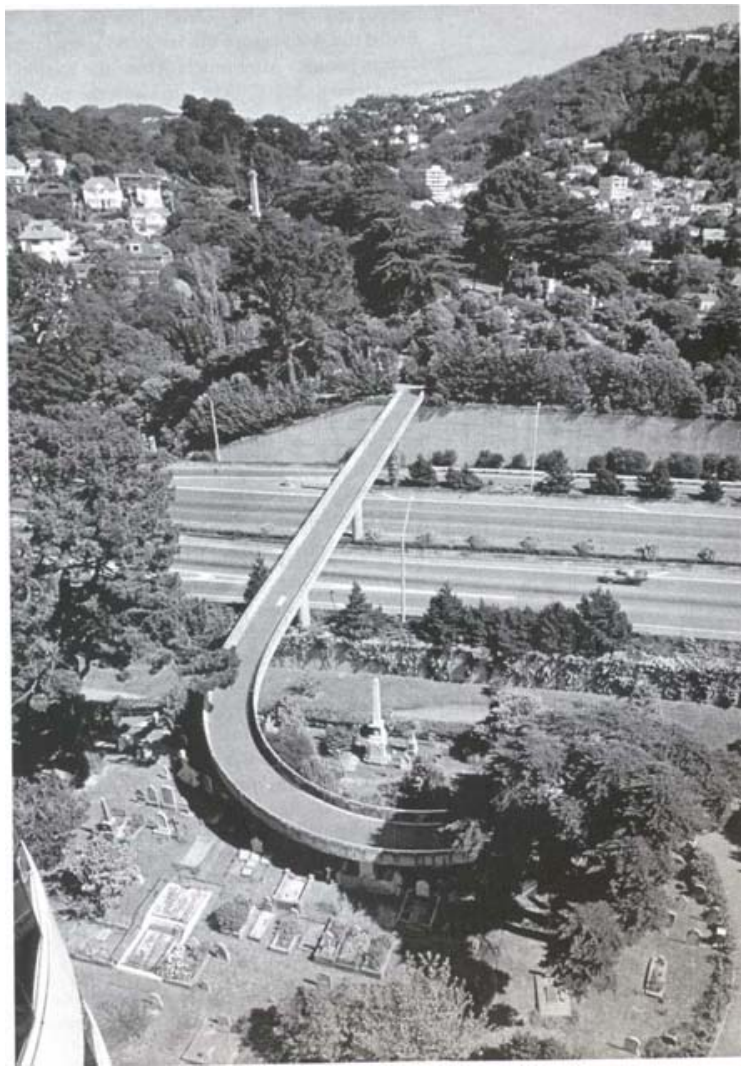

Bolton Street Memorial Park and footbridge [Wellington City Council, p.

22]. 


\section{Description:}

Bolton Street Memorial Park is a designated Historic Reserve under the Wellington City District Plan. It is also a Historic Place under the New Zealand Historic Places Act 1993. Bolton Street Memorial Park is the site of the Bolton Street Cemetery which was dissected by the Wellington urban motorway. Part of the cemetery was in the path of the motorway, while the majority remains.

\section{History:}

The Bolton Street Cemetery was 18 acres of common burial ground established in 1841 under the direction of the New Zealand Company. Space for Jewish (1852) and Church of England (1851) burials was later separated out from the common burial ground, and Roman Catholics had another area for their dead. ${ }^{314}$

In 1857, cottages were built for the sextons of both the public and Church of England cemeteries. The Church of England sexton's cottage still stands (please see entry for Sexton's Cottage), while the public cemetery's sexton's cottage was demolished in $1908 .^{315}$

The Bolton Street Memorial Park is the resting place of more than 8,000 of Wellington's earliest residents. The cemetery was closed in 1892 to all but burials in existing plots. It was closed entirely in 1967. The cemetery consisted of mostly British and European stock, although there were about 80 Maori graves. The Karori cemetery opened in 1891 after concerns were raised about having a cemetery in what was now a densely occupied area. ${ }^{316}$

In the 1960s the site was chosen as the path of the new Wellington Urban Motorway. There was a public outcry about the destruction of the cemetery, and a Bolton Street Cemetery Preservation Society was established. However, the Act allowing the motorway was passed in 1967, and work began in 1968. ${ }^{317}$ The cemetery was to lose 3.7 acres from its centre, where some of the oldest graves were (some 3,700 graves were shifted). ${ }^{318}$ The Preservation Society insisted that the area be given high design priority, and that the remains be carefully disinterred, and historic gravestones be photographed and kept for reestablishment when the motorway was complete. The cemetery section of the motorway was opened in 1978, and the headstones 'scrupulously' replaced by March 1979. ${ }^{319}$

The Memorial Park has many existing mature trees and ornamental plantings dating back to the early days of the cemetery. ${ }^{320} \mathrm{~A}$ footbridge connects the two parts of the cemetery, and an extension which included the reconstructed mortuary chapel and the sexton's cottage were added in 1990. The spot was planted with heritage roses and has become popular as a 'romantic' park. Paths through the Park were

\footnotetext{
${ }^{314}$ Alington, pp. 131-133.

315 Alington, pp. 134-135.

${ }^{316}$ Alington, pp. 130-131, 141-142.

317 Alington, pp. 144-146, 148.

318 Tritenbach, p. 76.

${ }^{319}$ Alington, pp. 144-146, 148.

320 Wellington City Council, p. 35.
} 
named to commemorate people such as the sextons who administered the cemeteries. $^{321}$

\section{Modification:}

The Wellington Urban Motorway bisected the Bolton Street Cemetery, and greatly altered it.

\section{Level of authenticity:}

However, many of the headstones have been returned to their original resting places, or near to them. Much of the original wrought iron has also been replaced.

\section{Assessment of significance/heritage values:}

\section{Historical}

The Bolton Street Memorial Park is the burial ground of 8,000 of Wellington's earliest residents such as Edward Gibbon Wakefield and John Plimmer. Prime Minister Richard Seddon is also buried there. The gravestones tell the stories of Wellington settlers and the hardships of living in a new colony. The Memorial Park is a special part of Wellington's history.

The cemetery is a good example of a nineteenth century burial ground, with stone, iron and wooden memorials, statuaries and crosses. The number and variety of fenced graves is rare in New Zealand and are both attractive and historically important. 322

The Bolton Street Memorial Park is rich in historic artefacts and plants, and is considered to have wild, 'old world' qualities. ${ }^{323}$

\section{Spiritual}

As the Bolton Street Memorial Park is also a cemetery, it is a spiritual place, with special meaning to the descendants of those who are buried there.

\footnotetext{
321 Wellington City Council, 'Wellington Botanic Garden incorporating Bolton Street Memorial Park' brochure, no date. 322 Wellington City Council, Combined Management Plan, p. 22.

${ }^{323}$ Wellington City Council, pp. 31-32.
} 


\section{Anderson Park}

Anderson Park is not recognised by the New Zealand Historic Places Trust or the Wellington City Council District Plan

Lot 1 DP 50793 (2.8202 ha), Recreation Reserve, Gazette 1980, page 4060

Map reference (46)

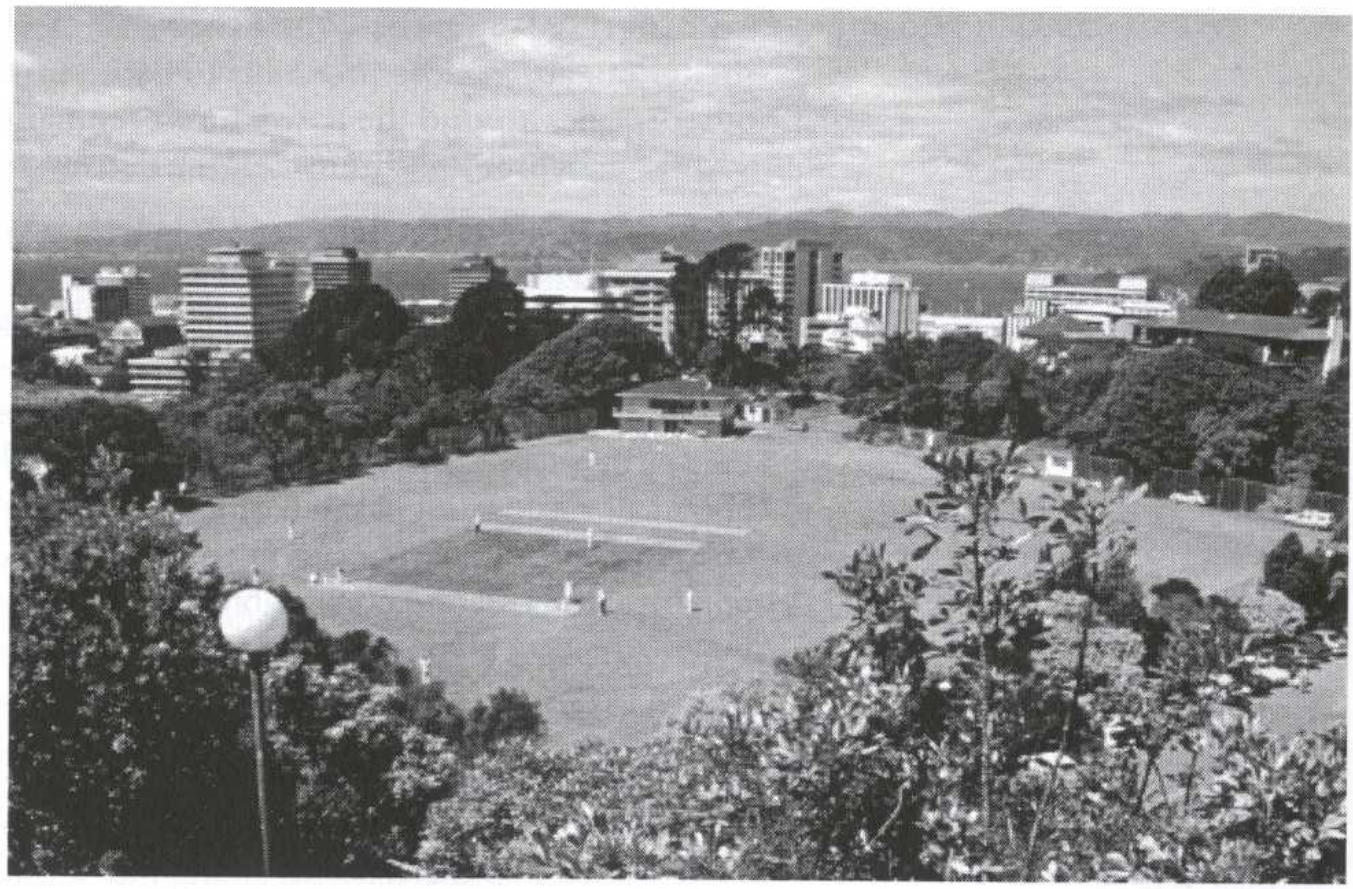

Anderson Park [Shepherd, Wellington's Heritage, p. 220].

\section{Description:}

Anderson Park is a sports field adjoining the Botanic Garden. Anderson Park is named after Councillor George Anderson, who championed the creation of the park. ${ }^{324}$

\section{History:}

The need for a recreation ground in Thorndon was an issue from at least the $1880 \mathrm{~s}$ when Councillors George Anderson and Dr. A.K. Newman estimated that it would cost about $£ 4500$ to develop a park at Sydney Street. However, money was a problem, and it was not until 1906 that a loan was raised to construct the park. ${ }^{325}$ Mssrs Hulme, Henry and Mathews were contracted to remove trees and clear the valley in preparation for the earthworks. ${ }^{326}$ Anderson Park was once Glenbervie Hill, which was levelled by hoppers, trucks, a tramway and a steam digger. Unemployed men provided the labour. It was not until late 1910 that the park was

\footnotetext{
${ }^{324}$ Alington, p. 142.

325 Alington, pp. 142-143.

326 Shepherd, p. 238.
} 
ready for organised games. ${ }^{327}$ The park also had a children's playground, which was dismantled in 1934 and shifted to the Botanic Garden. ${ }^{328}$

Anderson Park was extended during 1931-1934. The gully, which had formed when Glenbervie Hill had been levelled, had to be filled. Extensive storm water drains were also laid. Again, unemployed labour was used to produce the extension. This time it was a Depression work relief scheme. The new land was used as sports fields until the Second World War when all of Anderson Park was used as an American Marine Camp. After the Second World War the land was used again as a sports ground, until part of the site was used for the Lady Norwood Rose Garden. ${ }^{329}$

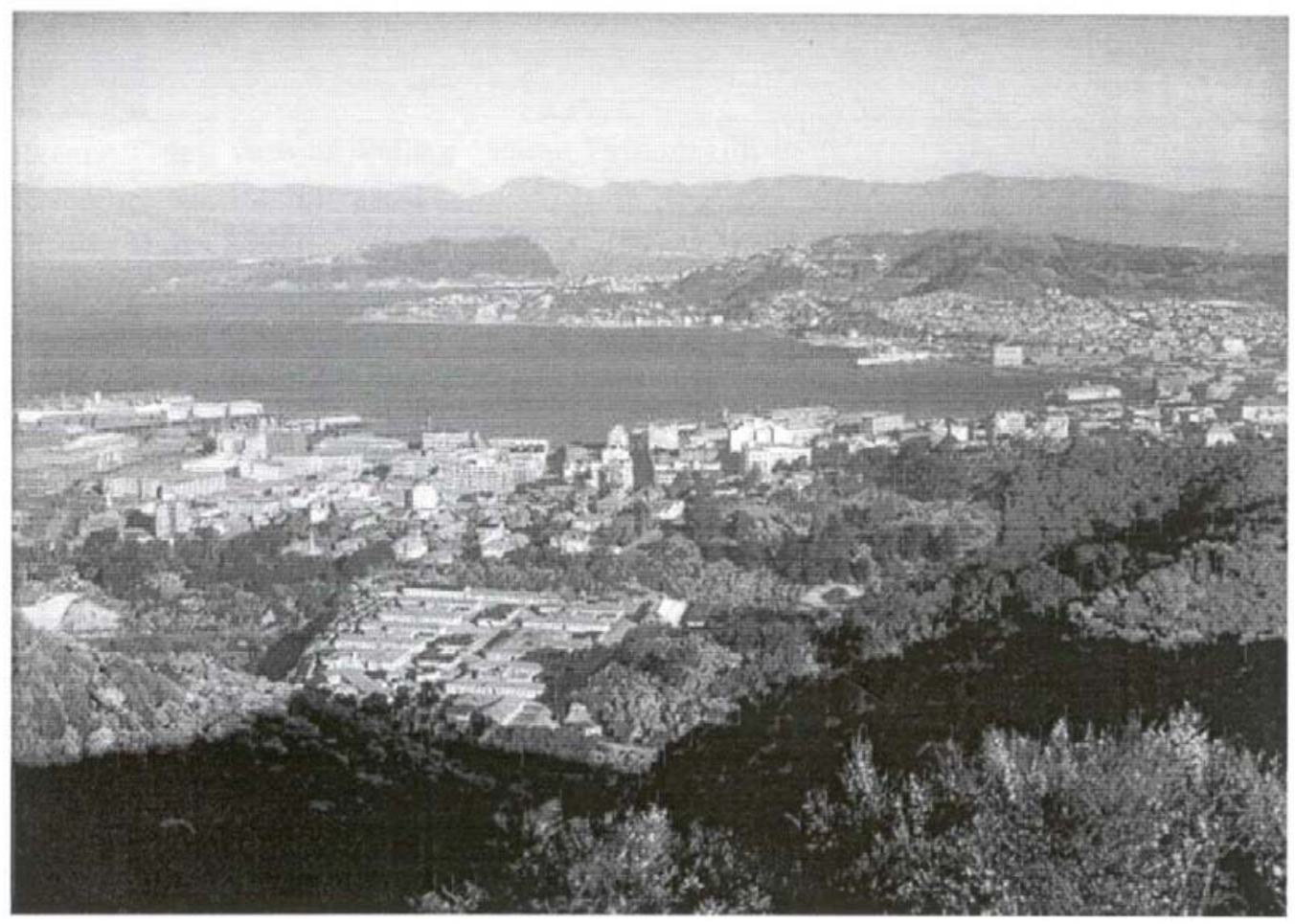

View of Anderson Park showing WWII camp [Source: Alexander Turnbull Library,

\section{Level of authenticity:}

1/2-100724; G. ]

Still used for its original purpose, although some of the land was taken for the Lady Norwood Rose Garden.

\section{Assessment of significance/heritage values:}

\section{Historical:}

Anderson Park has been used as a sports ground for 93 years.

The ground was also used as a camp for American soldiers during the Second World War.

\footnotetext{
${ }^{327}$ Alington, p. 143.

328 Shepherd, p. 250.

${ }^{329}$ Shepherd, p. 248.
} 


\section{Recommendations:}

The Wellington Botanic Garden and the areas contiguous to the Garden have many sites of important historic, cultural and heritage value. This Heritage Inventory has aimed to identify, research and assess the various sites. From the research undertaken it is clear that the Botanic Garden as a whole, as well as many of the buildings, features and spaces within it, have a strong connection to the history of New Zealand, Wellington City and Wellington City Council. There are also strong ties to science, horticulture and astronomy, the Scouting movement and the public.

There are over 200 records relating to the Botanic Garden held at the Wellington City Council Archive. No doubt more could be discovered about the Botanic Garden and the buildings, features and spaces within it if further research was undertaken. Oral histories from gardeners and staff who used to work at the Botanic Garden would also yield many interesting social history elements.

In particular, further research into the role of the Botanic Garden pines and New Zealand forestry would be worthwhile. Also, the Maori cultivation areas near Upland Road should be further investigated, and possibly interpreted for Garden visitors. Perhaps a Maori heritage walk could be established at the Garden, highlighting native trees and plants and the Maori history of the area.

Care should be taken during excavation work or development of any of the sites listed in the Heritage Inventory. Professional historians or archaeologists should be present to oversee any work done on historical sites, buildings, features or spaces. Any work carried out should be sensitive to the nature of the buildings, features or spaces within the Garden, as well as to the nature of the Garden overall. The nature and atmosphere of the Botanic Garden, such as the Victorian Main Garden, native remnants and later plantings, should be maintained.

While there is currently a plaque on the side of the Lawson Scout Hall, I believe more information should be available about the Scout Hall and the history of the Scout troop. Linking the Scout Hall to its history as part of the Botanic Gardens Battery would also be appropriate. The Wellington City Council and the Scouting Movement should work together to produce an appropriate interpretive panel, incorporating the history of the Scout Hall as part of the Botanic Garden Battery, Cable Car and Scouting Movement. The Scout Hall could also possibly be registered, as it fulfils criteria in respect to its association with the Scouting Movement and the Botanic Garden Battery. It is one of few remaining ancillary buildings relating to coastal defence; it is the oldest Scout Hall in the New Zealand and it is part of the historic Observatory Precinct.

Currently a garden seat marks the location of Annie's Seat near the Children's Playground. It seems that between the writing of Shepherd and Cook's The Botanic Garden Wellington, A New Zealand History 1840-1987 and today, the name Annie's Seat has disappeared from maps of the Botanic Garden. A plaque acknowledging the historical name of Annie's Seat and the work of the early keepers should be attached to the garden seat which already marks the site. The site has been known as Annie's Seat since 1875, and reveals the social history of the Botanic Garden and the Keepers/Curators/ Directors and their families who have lived at the Botanic Garden - this story should not be lost. 
Currently, as seen by the boundary map of the Botanic Garden, Anderson Park and Bolton Street Memorial Park (p. 5), the boundary between Anderson Park and the Garden is very untidy and confusing, with the boundary of Anderson Park currently crossing through part of the Lady Norwood Rose Garden. A rationalisation of these boundaries is necessary. Anderson Park could be absorbed as part of the Botanic Garden, or the current boundaries could be changed for clarity.

Nester and Cochran suggest excavation to determine the extent of the Botanic Garden Battery in the Observatory Precinct.

The Main Gates at the Founders Entrance of the Garden are beginning to rust through the paint: preservation or conservation work should be undertaken to return the gates to a good condition.

The Mess Room and Stables now appear in the Wellington City Council's Heritage Inventory. Perhaps they should also be recognised in the District Plan or by the Historic Places Trust. The Mess Room and Stables are a beautiful example of Arts and Crafts architecture, they are a long-serving Wellington City utility and relate to the rustic and Romantic elements of the Botanic Garden. The Carter Observatory has done well in saving the Thomas King Observatory from disrepair and disintegration. The Thomas King Observatory was once the country's leading astronomical research facility, and was used by both amateur and well-known scientists. It is closely related to the Wellington Philosophical Society and is part of the Observatory Precinct. The Thomas King Observatory should be acknowledged in the District Plan, Council Heritage Inventory or by the Historic Places Trust.

The Bolton Street Memorial Park and Observatory Precinct are already recognised for their unique elements. As well as individual features such as the Overseer's Cottage and the Mess Room and Stables which meet the registration criteria as Historic Places, the Wellington Botanic Garden also meets the criteria for being registered as a Historic Area. ${ }^{330}$

The Wellington Botanic Garden is associated with events, persons or ideas of importance in New Zealand history. These people include Sir James Hector, who was responsible for most aspects of science in New Zealand during the 1870s and 1880s; and the many premiers, colonial secretaries and colonial agents who sat on the Botanic Garden Board. The Garden is associated with colonial agencies such as the Colonial Museum, the Colonial Observatory and the New Zealand Institute. The Wellington Botanic Garden played an essential role in New Zealand's settlement through the acclimatisation of plants. The Wellington Botanic Garden is also associated with New Zealand forestry though trials and distribution of conifer seeds.

There is a high level of public esteem for the Wellington Botanic Garden. There have been a number of books written about the Botanic Garden, it is central to many of Wellington City's festivals and various organisations such as the Wellington Herb Society are active at the Botanic Garden. There is also the Friends of the Wellington Botanic Garden, and the Botanic Garden is a key tourist attraction to Wellington City as well as a treasure for the Wellington public.

The Wellington Botanic Garden is closely involved with public education programmes. These include initiatives with the World Wide Fund for Nature, who

\footnotetext{
330 Historic Places Act 1993, s23(2).
} 
has an office at the Treehouse Interpretive Centre. The Education Officer works with groups from primary school age to tertiary level, including outreach into schools and the community as well as education programmes run at the Garden. The Botanic Garden's education programmes emphasis learning about New Zealand's flora and fauna and conservation. The Botanic Garden staff also run horticultural demonstrations and lectures for the wider public.

The Wellington Botanic Garden retains elements of design features from many different periods of its 134-year history. The Main Garden has a Victorian feel, with exotic trees such as palms combined with formal bedding. The Lady Norwood Rose Garden is also based on High Victoria formal gardens, while other parts of the Garden, such as the pines, Druid Hill and the native bush remnant reflect the Romantic Movement. Various features and buildings also tie into the rustic atmosphere of the Garden.

The Wellington Botanic Garden also meets symbolic and commemorative criteria, as there are many commemorative plaques and gardens within the Botanic Garden. These include the Peace Garden, with the Hiroshima flame, the commemorative plaque to Wellington Bandsmen who died during the First and Second World Wars, as well as the many commemorative plaques to friends of the Garden on garden seats. The Botanic Garden is also symbolic as a place of beauty in the middle of the nation's capital city and as an example of the beliefs and values of the Romantic Movement.

The Wellington Botanic Garden is a historic landscape. It has been in existence since 1869 as a botanic garden with ties to colonial government and Wellington City. The 25 hectares includes several buildings of historical and architectural value, as well as features such as the Main Gates and the Gazebo/summerhouse. The Botanic Garden incorporates vastly different environments, from pinetums to High Victorian rose gardens. The Botanic Garden provides distinct habitats for native birds and reptiles. The Botanic Garden is part of the greater landscape of the Town Belt, and also includes the unique environment of the pre-European settlement native bush remnant. The Wellington Botanic Garden is closely associated with other historic landscapes and areas such as the Bolton Street Memorial Park and the Observatory Precinct.

The Wellington Botanic Garden also meets the criteria of the Florence Charter for historic gardens. ${ }^{331}$ The Charter recognises unique place of the Wellington Botanic Garden in the middle of Wellington City; the Charter recognises the atmosphere and ambiance of the Wellington Botanic Garden, as well as the various stages of its development and use over time. The Florence Charter also stresses the importance of the educative role of the botanic garden, which is reflected in the strong educative focus of the Wellington Botanic Garden. The Charter emphasises the need to identify, list and protect historic gardens. The Botanic Garden also fits many of the criteria of places of cultural heritage value as defined by ICOMOS. These include the Wellington Botanic Garden's lasting values and long period of use; the Garden's ability to teach us about the past through interpretive material and objects such as trees, plants, buildings and spaces; and the Garden's role in providing context for community identity. The ICOMOS Charter also defines a place of cultural heritage value as a place which demonstrates continuity with the past, present and future. ${ }^{332}$ This can be seen at the Botanic Garden through the old

\footnotetext{
331 http:// www. international. icomos. org/ charters/ gardens_e. htm

332 http:// www.icomos.org/docs/nz_92charter.html
} 
trees, traditional bedding displays, interpretive material and education programmes the Botanic Garden runs in conjunction with the World Wide Fund for Nature.

As the Botanic Garden meets so many of the criteria of the New Zealand Places Trust, the Florence Charter and the ICOMOS Charter, I recommend that the Wellington Botanic Garden be recognised as a historic area by the New Zealand Historic Places Trust. 


\section{Appendix}

The following lists holdings of archival material used in this Heritage Inventory (and may be useful for further research):

Wellington City Council Archives

\section{[A22] 00001:631:20/30 Statue 'J oy' Botanical Gardens}

Letter from Assistant District Public Trustee to Town Clerk, 7 May 1930 - advises that a bequest has been made by Martin James Kilgour for the sum of $f 100$ for a 'piece of statuary for the Botanical Gardens, Wellington'

Letter from Assistant District Public Trustee to Town Clerk, 23 J une 1930 - advises payment of $75 \%$ of Kilgour Bequest

Memorandum from J.G. MacKenzie, Director of Parks and Reserves, to Town Clerk, 21 J uly 1930 - states that site is available for Kilgour Statuary

Memorandum from J ohn O'Shea, City Solicitor, to Town Clerk, 4 August 1930 believes that the current design is not appropriate

Opinion from John O'Shea, City Solicitor, to Town Clerk, 24 September 1932 believes that the current design 'is not within the bounds of the testators wishes'

Letter from Burton Holt (Chelsea) Ltd Landscape and Floral Artists to J.G. MacKenzie, 12 May 1938 - tenders quote for constructing given design at $£ 72.10 .0$

Memorandum from J.G. MacKenzie, Director of Parks and Reserves, to Town Clerk, 1 J uly 1938 - attaches catalogue of garden statuary

Memo from K.E. Luke, City Engineer, to Town Clerk, 25 August 1941 - description of pool, and balance of Kilgour Bequest now at $f 104$. Says that they are 'honour bound to proceed with the major work as soon as possible' because the bequest was made in 1930.

Memorandum from J.G. MacKenzie, Director of Parks and Reserves, to Town Clerk, 29 August 1941 - worries about appropriateness of current design, and shortage of funds because of war

Memorandum from Town Clerk to Councillors MacAlister and Duncan, 3 September 1941 - suggests that a competition be held to find designs for the Kilgour Statuary

Memo for Town Clerk, 31 March 1942 - notes that the Kilgour Bequest will be raised at next Reserves Meeting

Letter from A.R. Fraser ARCA to Mr. Atkinson, Engineer City Council, 25 J une 1942 wishes to clarify contract details

Memorandum from J ohn O'Shea, City Solicitor, to Town Clerk, 24 J uly 1942 - notes that contract no. 1677 has been forwarded to Town Clerk's office

Memo from K.E. Luke, City Engineer, to Town Clerk, 27 J anuary 1945 - notes that Luke has inspected Fraser's sculpture 
Memo from K.E. Luke, City Engineer, to Town Clerk, 29 J anuary 1945 - discusses Fraser's progress and contract

Memorandum from J.G. MacKenzie, Director of Parks and Reserves, to Town Clerk, 27 J une 1945 - queries when pool etc will be completed

Memo from K.E. Luke, City Engineer, to Town Clerk, 5 November 1945 - sculptor prefers round pool and suggests frogs

Memo from K.E. Luke, City Engineer, to Town Clerk, 9 November 1945 - notes that 'Joy' sculpture has been temporarily placed in foyer of public library pending fixture

Memo from K.E. Luke, City Engineer, to Town Clerk, 31 J anuary 1946 - discusses post-war concrete situation

Correspondence from K.E. Luke, City Engineer, to Town Clerk, 23 September 1946 accepts Fraser's quotation for delivering and fixing 'J oy' statue

Letter from Mayor to Mrs. H.S. Royle, 10 December 1946 - apologises for not inviting Mrs. Royle to unveiling of her brother's bequest: the 'J oy' statue

[C47] 00277:325:28/6/56 Historic Places: Glenmore Street: Botanical Gardens, Gazebo and Environs

16 black and white photographs taken in December 1978 by Deric Buchan. Subjects include: 'tool houses', main gates, 'overseer's cottage', 'phone booth, Main Entrance' and 'Frog Pond'

Photocopy of the Gazebo, reference Cityscapes, by David McGill and Grant Tilley

Research Record Form, J anuary 1977 - notes that gazebo/summerhouse would be an 'excellent' prospect for preservation and conservation

Plans for pavilion at Duck Pond, 1996

Boffa Miskell's report for permission to upgrade Duck Pond, 31 J anuary 1996

Assessment - Botanic Garden Duck Pond, Boffa Miskell, 11 J anuary 1996

Dr. Wayne Orchiston, 'The Wellington Botanic Garden and Its Historical Astronomical Observatories', Historic Places 1995 (manuscript)

James McKenzie, 'Dominion Observatory Precinct', Historic Places Trust report, 1984 (manuscript)

J.B. Seymour, 'A History of the Thomas King Observatory, Wellington', no date (manuscript)

Works Consultancy Services Ltd, 'Thomas King Observatory, Kelburn, Building Assessment for Wellington City Council', c. 1994-5

Letter from Wayne Orchiston, Executive Director of Carter Observatory, to Mr. N. Lewthwaite, Re: Conservation of the Thomas King Observatory, $6 \mathrm{~J}$ une 1995 


\section{[A17] 00001:499:11/7 Conveniences at Scout Hall, Botanical Gardens}

Memo from K.E. Luke, City Engineer, to Town Clerk, 16 February 1937 - notes the need to convert a private drain into a public drain so that Scout Hall can have toilets

\section{[A210] 00057:5:87/11 Reclassification of Dominion Observatory, Salamanca Rd, Kelburn}

Memorandum from K.V. Clarke, City Planner, to Town Clerk, 17 March 1987 discusses New Zealand Historic Places Trust is planning to upgrade the Dominion Observatory's classification.

Wellington City District Scheme Promulgation of Scheme Change, 1 May 1987

Correspondence from Ms. Chris Ross, Advisory Officer NZHPT, to the Town Clerk, 9 J une 1987 - stresses national significance of the Dominion Observatory

Wellington City Council, Proposed Changes to Operative District Scheme, 1987

\section{[A153] 00009:1021:50/885 Scout Hall - Rawhiti Terrace - Botanical Gardens}

Specifications and quote for installing toilets and hand basins

\section{[A135] 00009:486:31/21/10 Botanical Gardens - Erection of Soundshell}

Wellington City Corporation, Specification and General Conditions Contract for Construction of Sound Shell Building, Botanical gardens, Wellington, 19 October 1951

Memorandum from E. Hutt, Director of Parks and Reserves, to City Engineer, 9 August 1948 - mentions need to set up meeting with Mr. Osten, the Wellington Band Association's architect

Correspondence from Acting City Engineer to the District Controller, 8 September 1948 - discusses pound for pound scheme with Bandsmen and Council

Correspondence from S.W.P Jones, District Building Supervisor, to the City Engineer, 29 September 1948 - notes that the Ministry of Works declined current proposal

Correspondence from Acting City Engineer to Mr. W. Currie, Secretary Wellington Bands Association, 26 October 1948 - discusses using concrete as the main building material

Correspondence from City Engineer to W.E. Currie, Secretary Wellington Bands Association, 14 November 1949 - queries when Sound Shell is to go ahead

Authority to Proceed with a Constructional Work, issued by the District Building Controller, 18 November 1949

Plan of proposed Sound Shell, signed by J.K. Richardson, 23 J uly 1951 
Proposed Sound Shell Botanical Gardens, Wellington, Specifications, signed by R. A.E. Osten, August 1951

Cutting from Evening Post, 'Design for Wellington's Sound Shell', 8 August 1951

Memorandum from City Engineer to the Director of Parks and Reserves, Re: Sound Shell: Botanical Gardens: Roofing Material and Paint, 26 September 1951

Correspondence from City Engineer to Town Clerk, 25 October 1951 -advises to advertise for tenders for construction of Sound Shell

Memorandum from City Engineer to Town Clerk, 14 November 1951 -advises that there have been no tenders received

Memorandum from Town Clerk to City Engineer, 10 December 1951 - note to advise that there are still no tenders

Memo from City Engineer to Town Clerk, 17 April 1952 - notes that two tenders have been received, but are unacceptable

Cutting from Evening Post, 'Sound Shell Tenders Too High', 6 May 1952

Note re: advertising tender, 1 September 1952

Memo from City Engineer to Town Clerk, 9 October 1952 - tender received but too expensive

Cutting from Evening Post, 'Sound Shell To Be Ready in Five Months', 12 March 1953

Cutting from Dominion, 'Sound Shell to be Built in Gardens', 12 March 1953

Cutting from Dominion, 'Sound Shell to be built in Gardens', 12 March 1953, p. 9

Memo from City Engineer to Town Clerk, 18 March 1953 - notes that plans advertised in newspaper not current plans

Invitation to Opening Ceremony and Unveiling of Memorial Plaque, Band Sound Shell, B. O. Peterson, Town Clerk, 25 November 1953

Letter from Mayor to City Engineer, 4 December 1953 - notes urgent need to seal paths to Sound Shell in preparation for function on 5 December

Newspaper cutting, 'Only One Band to Attend - Dispute to Mar Opening of New Sound Shell?', no date

Cutting from Evening Post, 'Soundshell Blacklisted?', 4 December 1953

Cutting from Dominion, 'Bands' Invitation Not Lackadaisical, W'gton Mayor Says', 5 December 1953

Cutting from Dominion, 'Soundshell Opening Invitation', 7 December 1953

Cutting from Dominion, 'Mayor Opens Sound Shell For Bands in Botanical Gardens in Wellington', 7 December 1953 
Cutting from Evening Post, 'Sound Shell Opened by The Mayor', 7 December 1953

Cutting from Dominion, 'New Sound Shell Opened', 7 December 1953

Cutting from Evening Post, 'Band 'Under Army Orders', Says Secretary', 7 December 1953

Report about Opening of Sound Shell: Botanic Gardens for Mayor (manuscript)

Cutting from Dominion, 'No Sound From W'gton's Sound Shell Yesterday', 14 December 1953

Cutting from Dominion, 'Another Opening of Memorial Shell Demanded by Bands', 15 December 1953

Cutting from Dominion, 'Third Leader...', 16 December 1953

Cutting from Dominion, 'Bandsmen's Cenotaph', 17 December 1953

Cutting Evening Post, 'Concerts, Open-Air Dancing/ Gardens Soundshell Should Be Big Asset', 19 J anuary 1954

Cutting from Evening Post, 'Lighting Effects at Sound-Shell', 1 December 1954

Letter from Mr. Hill to the Mayor, re: Memorial Sound Shell, 9 J anuary 1955

\section{[A7] 00001:199:6/637 Sound Shell: Botanical Gardens Reserve (General)}

Letter from Lt. T. Herd, Bandmaster Wellington Garrison Band, to Town Clerk, 24 October 1905 - notes that current band rotunda is too small

Letter from J.T. Watson, Architect and Structural Designer, to Mayor, 12 J anuary 1935 - suggests that if another band rotunda is built at the Garden it should be in sound shell style

Letter from L. Baker, Honorary Treasurer of Wellington Band Association, to Town Clerk, 9 February 1950 - encloses $£ 20.15 .10$ raised through hymn contest held at the Garden

Letter from L. Baker, Honorary Treasurer of Wellington Band Association, to Town Clerk, 24 March 1950 - encloses £22.15.0 raised through Australian Navy Band concert

Letter to the Editor, Dominion, 'The Sound Shell', 7 September 1950 - writer is worried that trees will be cut down to make way for the proposed Sound Shell

Letter from Ian F. Bown, Secretary Greater Wellington Electors Association Inc, to Town Clerk, received 1 November 1950 - suggests that the new Sound Shell be built in Anderson park

Memorandum from Director of Parks and Reserves to Reserves Committee members, 9 J anuary 1951 - summarises Wellington Beautifying Society's view that the new Sound Shell should be built at Newtown Park, encloses map and plan 
Memo from Town Clerk to Reserves Committee, 5 February 1951 - advises that the Bandsmen would prefer the proposed site at Botanic Garden

Letter from Town Clerk to J.H. Mclvor, Secretary Wellington Beautifying Society, 17 May 1951 - explains that site at Botanic Garden has been selected and that Sound Shell will replace current band rotunda

Osten's plans of the Sound Shell, dated 31 J uly 1951

Cutting from Dominion, by L.C. Smith, 'Band Sound Shell', 25 J uly 1952

Memorandum from Edward Hutt, Director of Parks and Reserves, to Town Clerk, 2 March 1953 - outlines the plan to construct the Sound Shell with cooperative labour for the cost of no more than $£ 4,000$. Contains notation that the motion was adopted by the Reserves Committee on 11 March 1953

Numerous invitations to attend the unveiling of memorial tablet and Sound Shell on Saturday 5 December 1953, all dated 25 November 1953

Letter from Town Clerk to W.E. Currie, Secretary of Wellington Bands Association, 9 April 1954 - discusses upcoming ANZAC day commemorations at the Sound Shell

Memorandum from Edward Hutt, Director of Parks and Reserves, to Town Clerk, 23 April 1954 - discusses need for permanent lighting and dressing rooms at the Sound Shell

\section{[A35] 0001:1042:31/290/2 Reserve: Botanical Gardens Magpie Lawn}

Letter from Honorary Secretary Kelburn Normal School PTA to Town Clerk, 22 May 1952 - suggests that Magpie Lawn be available for use by local children

Letter from Edward Hutt to Town Clerk, 30 May 1952 - outlines bylaws associated with Magpie Lawn and its use as a sports ground

Letter from Honourable J.R. Marshall to Town Clerk, 12 August 1955 - states that Kelburn Normal School has no playground and should have access to Magpie Lawn

Letter from Edward Hutt to Town Clerk, 30 September 1955 - responds to Marshall's letter and restates that Magpie Lawn is inappropriate for use as a sports ground

Letter from Town Clerk to Honourable J.R. Marshall, 13 October 1955 - restates policy on Magpie Lawn

Letter from J.R. Marshall to Town Clerk, 24 November 1955 - further discussion about Magpie Lawn

Memorandum from Edward Hutt to Town Clerk, 2 December 1955 - regarding Marshall's letter. Restates that Magpie Lawn is not appropriate for games i.e. soccer because of possible damage to shrubbery

Letter from Honourable J.R. Marshall to Town Clerk, 6 March 1956 - challenges the legal authority of the City Council to make the decision not to allow the school to use Magpie Lawn 
Note from E.P. to Town Clerk, 25 May 1956 - suggests that Kelburn Normal School should ask to use Appleton Park instead

[A130] 00009:341:11/39 Contract No. 1405 Male Conveniences: Nairn St Reserve; Ladies Rest Room: Botanical Gardens, General Files - Nairn St Conveniences 31/48/1, Botanical Gardens Rest Room 21/21/4

Wellington City Corporation, Specification and General Conditions, Contract no. 1405: Contract for Erection of Conveniences for males, Nairn Street Reserve and Ladies Rest Room Botanical Gardens, Wellington, 8 November 1929 - includes City Engineer's estimate

Memo from City Engineer to the City Solicitor, 27 November 1929 - confirms Mssrs McLean and Gray Ltd as contractors

City Engineer, Botanical Gardens Ladies Rest Room Amended Drainage Plan, sketch no. 284 , reference no. $29 / 1382$

[A135] 00009:486:31/21/3 City Engineers Department, Residences - Botanical Gardens. Director of Parks and Reserves. Custodians

Memorandum from J.G. MacKenzie, Director of Parks and Reserves, to City Engineer, 26 April 1928 - notes that chimney pot needs to be erected and brick copper needs to be rebuilt

Wellington City Corporation, Specifications and General Conditions, Contract no. 1397, Contract for Alterations and Additions to Residence; Botanical Gardens: Wellington, 12 August 1929

City Engineer's Department, plan of Alterations Residence Botanical Gardens, 19 J une 1929 - plan of proposed extension

Memorandum from J.G. MacKenzie to the City Engineer, 27 J une 1929 - reports leaky roof

Engineer's Department, plan of Additions to Residence, Botanical Gardens, tracing no. 4666, signed L.A. 3 J uly 1929

City Engineer's Estimate: Schedule of Prices

Memorandum from City Engineer to Town Clerk, 22 August 1929 - notes tenders for alterations and additions to the residences

Memorandum from J.G. MacKenzie to City Engineer, 18 December 1929 - notes that damaged floor also needs to be repaired

Memorandum from J.G. MacKenzie to City Engineer, 11 October 1934 - requests sketch for possible soil shed and estimated cost

G.A. Hart, City Engineer's Department, plan of Soil and Tool Shed Botanical Gardens for Reserves Department, sketch no. 691, reference no. A341224

Memorandum from City Engineer to Director of Parks and Reserves, 30 October 1934 - states that proposed soil shed would cost $f 98$ to build 
Memorandum from J.G. MacKenzie to City Engineer, 18 J une 1941 - requests prices to renovate hall and bathroom in Director's Residence

Memorandum from L. A. to City Engineer, 27 J une 1941 - reports on current state of hall and bathroom in Director's Residence and recommends renovations to amount of $£ 86$

Quotation from Winstone Limited for Wintex Flooring, 2 September 1941 - f11.7.6 to supply and fix rubber to bathroom floor

Letter from City Engineer to Town Clerk, 16 September 1941 - reports that the renovations to the Director's Residence are more extensive than first expected because of state of water pressure and condition of the bathroom

Memorandum from City Engineer to Town Clerk, 23 September 1941 - reports that the renovations to the Director's Residence are costing more than first expected because of the condition of the building

Memorandum from City Engineer to the Director of Parks and Reserves, 23 October 1946 - outlines renovations to the Caretaker's Cottage

City Engineer's Department, Repairs and Additions to Caretaker's Cottage, Botanical Gardens, 24 October 1946 - lists work required to cottage, estimated cost $£ 590$

Letter from City Engineer to District Building Controller, 26 March 1947 - outlines renovations to Director's Residence

City Engineer's Department, plan for Proposed Alterations to Residence, Botanical Gardens, reference no. A 47/65, 12 May 1947

City Engineer's Department, plan of Renovations to Caretaker's Cottage, sketch no. 1378, reference A47/ 14, 30 J uly 1947

Memorandum from City Engineer to the District Building Controller, 1 August 1947 notes urgent need for a bathroom at the Caretaker's Cottage

[A82] 000205:4:904 Contract for Construction of Stables and Mess at the Botanical Gardens, 30 October 1914

Letter from Town Clerk to Mssrs French and Hampton, 30 October 1914 - reports that their tender of $£ 339$ has been accepted

Standard Fire and Marine Insurance Company of New Zealand Ltd, Interim Fire Policy, 17 December 1914

City Engineer, Specification for the Erection of Stables etc, Botanical Gardens

Bond for Performance of Contract, 15 J anuary 1915

[A144] 00009:752:37/21 Housing - Erection of House for Head Caretaker, Botanical Gardens 
Memorandum from the City Engineer to the District Building Controller, 20 August 1947 - suggests that new residence for the head caretaker could be built from left over materials from U.S. military buildings

\section{$\underline{\text { National Library Photographic Collection }}$}

View of wooden seat beneath trees in the Botanical Gardens, Wellington, c. 1880s, reference: 1/ 1-025555; G

Mazsie Hislop with Mr and Mrs Mae in the Botanical Gardens, Wellington, February 1907, reference PA1-0-229-3

Summer display of Begonias in the Main Glasshouse of the Wellington Botanic Garden Nursery, 1944, reference 1/ 2-158046; F

Sir J ames Hector, c. 1900, reference MNZ-1161-1/2; F

View of Wellington from Tinakori Hill, 1944, reference 1/ 2-100724; G

Kelburn cable car, c. 1902, reference 1/2-008120; F

Men standing beneath an archway at the Wellington Botanic Garden, c. 1900s, reference 1/ 2-076592; G

Dominion Observatory, Wellington Botanic Gardens, c. 1900 (actually closer to 1907), reference 1/ 2-076775; G

Cable car, power house and Kelburn Tea Kiosk, Wellington, C. 1905-1930, reference 1/2-001613; G 


\section{List of Sources}

Alington, Margaret, 'Life After Death: An Old Cemetery Becomes a Memorial Park' in David Hamer and Roberta Nicholls The Making of Wellington 1800-1914 (Wellington: Victoria University Press, 1990), pp. 129-150

Ballara, Angela, 'Te Whanganui-a-Tara: phases of Maori occupation of Wellington Harbour c. 1800-1940', in David Hamer and Roberta Nicholls (eds), The Making of Wellington 1800-1914 (Wellington: Victoria University Press, 1990), pp. 9-34

Boffa Miskell Ltd with Chris Cochran, Wellington Heritage Building Inventory nonresidential buildings 2001 (Wellington: Boffa Miskell, 2001)

Campbell Pope Architect, Lawson Scout Hall Report, no date

Ehrhardt, Penny, Te Whanganui-a-Tara Customary Tenure 1750-1850 Waitangi Tribunal research series no. 3 (Wellington: Waitangi Division, Dept of Justice, 1993)

Hamer, David, New Towns in the New World: Images and Perceptions of the Nineteenth-Century Urban Frontier (New York: Columbia University Press, 1990)

Hepper, J. Nigel, Royal Botanic Gardens Kew: Gardens for Science and Pleasure (London: Her Majesty's Stationery Office, 1982)

Kernohan, David, Wellington's New Buildings (Wellington: Victoria University Press, 1989)

Kernohan, David, Wellington's Old Buildings (Wellington: Victoria University Press, 1994)

McGill, David, and Grant Tilly, Cityscapes (Wellington: Methuen Publishing New Zealand Ltd, 1977)

McLean, Gavin, Wellington: The First Years of European Settlement 1840-1850 (Auckland: Penguin, 2000)

Nester, Richard and Chris Cochran, Dominion Observatory and Gardens Battery Conservation Plan, including a specification for remedial work and regular maintenance (Wellington: Department of Conservation, 2003)

Orchiston, Wayne, 'Carter Observatory: The National Observatory of New Zealand, Information Sheet 5 'The Historic Astronomical Observatories in the Wellington Botanic Garden: A Brief Introduction"' (Wellington: Carter Observatory, September 1995)

Orchiston, Wayne, 'Carter Observatory: The National Observatory of New Zealand, Information Sheet 5 'The Historic Astronomical Observatories in the Wellington Botanic Garden: A Brief Introduction"' (Wellington: Carter Observatory, September 1995)

Orchiston, Wayne and Richard Dodd, 'Carter Observatory: The National Observatory of New Zealand, Information Sheet 1 'A Brief History of the Carter Observatory' (Wellington: Carter Observatory, September 1995) 
Ramsey, Juliet, Australian Heritage Commission Technical Publications, Series Number 2, Parks, Gardens and Special Trees: a Classification and Assessment Method for the Register of the National Estate (Canberra: Australian Government Publishing Service, 1991)

Salmond, Jeremy, Old New Zealand Houses 1800-1940, (Auckland: Reed Methuen Publishers, 1986)

Seymour, J ohn, 'Carter Observatory: The National Observatory of New Zealand, Information Sheet 9 'A History of the Thomas King Observatory' (Wellington: Carter Observatory, February 1997)

Shaw, Peter, New Zealand Architecture: from Polynesian Beginnings to 1990, (Auckland: Hodder and Stoughton, 1991)

Shepherd, Winsome, 'The Wellington Botanic Garden: an Important Historic Garden', Royal New Zealand Institute of Horticulture Annual J ournal, 12, 1984, pp. $109-111$

Shepherd, Winsome, 'Heritage, Botanic Garden, Volume I', unpublished, 1992. Held at Wellington Botanic Gardens Reference Library

Shepherd, Winsome, Wellington's Heritage Plant, Gardens and Landscape (Wellington: Te Papa Press, 2000)

Shepherd, Winsome and Walter Cook, The Botanic Garden Wellington, A New Zealand History 1840-1987 (Wellington: Millwood Press, 1988)

Siers, Judy, with Winsome Shepherd, The Botanic Garden: A Celebration of a Garden (Wellington: Culture and Recreation Division, Wellington City Council, 1992)

Tonk, Rosemary, "A Difficult and Complicated Question": The New Zealand Company's Wellington, Port Nicholson, Claim', in David Hamer and Roberta Nicholls (eds), The Making of Wellington 1800-1914 (Wellington: Victoria University Press, 1990), pp. 35-59

Tritenbach, Paul, Botanic Gardens and Parks in New Zealand: An Illustrated Record (Auckland: Excellence Press, 1987)

Wellington City Council, Combined Management Plan, Wellington Botanic Garden, Anderson Park and Bolton Street Memorial Park, J anuary 2002

Works Consultancy Services Ltd, Thomas King Observatory, Kelburn, Building Assessment for Wellington City Council, c. 1994-5 
Websites:

Wellington City Council Online Heritage Inventory, www.wcc. govt.nz/ wellington/ heritage/ inventory

ICOMOS Florence Charter,

http:// www. international.icomos. org/ charters/gardens_e.htm

ICOMOS New Zealand Charter for the Conservation of Places of Cultural Heritage Value, http:/ / www.icomos.org/ docs/nz_92charter.html 